San Jose State University

SJSU ScholarWorks

Master's Theses

Master's Theses and Graduate Research

Summer 2020

\title{
Effects of Urbanization and Habitat on the Diet and Reproduction of Red-shouldered Hawks in Central California
}

Catherine Y. Fisher

San Jose State University

Follow this and additional works at: https://scholarworks.sjsu.edu/etd_theses

\section{Recommended Citation}

Fisher, Catherine Y., "Effects of Urbanization and Habitat on the Diet and Reproduction of Red-shouldered Hawks in Central California" (2020). Master's Theses. 5123.

DOI: https://doi.org/10.31979/etd.3cc8-jy8q

https://scholarworks.sjsu.edu/etd_theses/5123

This Thesis is brought to you for free and open access by the Master's Theses and Graduate Research at SJSU ScholarWorks. It has been accepted for inclusion in Master's Theses by an authorized administrator of SJSU ScholarWorks. For more information, please contact scholarworks@sjsu.edu. 


\title{
EFFECTS OF URBANIZATION AND HABITAT ON THE DIET AND REPRODUCTION OF RED-SHOULDERED HAWKS IN CENTRAL CALIFORNIA
}

\author{
A Thesis \\ Presented to \\ The Faculty of the Department of Environmental Studies \\ San José State University
}

In Partial Fulfillment

of the Requirements for the Degree

Master of Science

by

Catherine Y. Fisher

August 2020 
(C) 2020

Catherine Y. Fisher

ALL RIGHTS RESERVED 
The Designated Thesis Committee Approves the Thesis Titled

EFFECTS OF URBANIZATION AND HABITAT ON THE DIET AND

REPRODUCTION OF RED-SHOULDERED HAWKS IN CENTRAL CALIFORNIA

\author{
by \\ Catherine Y. Fisher \\ APPROVED FOR THE DEPARTMENT OF ENVIRONMENTAL STUDIES \\ SAN JOSÉ STATE UNIVERSITY
}

August 2020

Lynne Trulio, Ph.D.

Department of Environmental Studies

Rachel O'Malley, Ph.D.

Department of Environmental Studies

Stephen Rottenborn, Ph.D.

H. T. Harvey \& Associates 


\title{
ABSTRACT
}

\section{EFFECTS OF URBANIZATION AND HABITAT ON THE DIET AND REPRODUCTION OF RED-SHOULDERED HAWKS IN CENTRAL CALIFORNIA}

\author{
by Catherine Y. Fisher
}

Urbanization alters biological community interactions and trophic structures compared to natural habitats; these changes may be reflected in the diets of apex predators such as raptors. The red-shouldered hawk (Buteo lineatus) is a dietary generalist that is expanding from natural and rural habitats into urbanized areas. In this study, direct observation was used to quantify the diet and reproductive success of red-shouldered hawks in Santa Clara County, California during the 2019 breeding season. GIS methods were used to quantify the nesting habitat and level of urbanization at each nest. Hawk diet consisted of mammals ( $50.4 \%$ by frequency and $77.7 \%$ by biomass) and reptiles $(20.9 \%$ by frequency and $11.1 \%$ by biomass), along with limited birds, frogs, and crayfish. The number of chicks fledged did not differ among urban, suburban, and rural nests, but the mean number of chicks fledged from successful nests was greater for rural nests than for suburban or urban nests. Nests were subject to high levels of external activity, with $93 \%$ from anthropogenic sources, but hawks responded to only $3.5 \%$ of nearby activity. Road length, developed landcover, and tree canopy cover significantly correlated with total prey biomass, mammal biomass and frequency, and reptile frequency. Red-shouldered hawks were able to find adequate prey to breed successfully over a range of urbanized habitats within Santa Clara Valley and are highly tolerant of human activity in this locality. 


\section{ACKNOWLEDGMENTS}

I could not have completed this thesis without the tremendous support of friends and family. My deepest thanks to my committee: Dr. Lynne Trulio, for guiding me through this work with infinite kindness, patience, and wisdom, and for being an inspiration to all women in raptor research; Dr. Rachel O'Malley, for welcoming me into her lab and constantly providing encouragement, new ideas, and feedback; and Dr. Stephen Rottenborn, for taking time out of his busy schedule to share his invaluable red-shouldered hawk expertise and guidance.

Thank you to my dear fiancé, Brice Colton, who gave me moral support from beginning to end and responded to every high and low alike with love, good humor, and chocolate. I could not ask for a better partner.

Thank you also to my family, who supplied financial assistance and boundless enthusiasm for my continued education, even if my statistical analyses will forever remain a mystery to them.

Finally, a heartfelt thank you to Dr. David Moriarty for sparking a passion for all things ornithological a decade ago, and forever changing the course of my life. 


\section{TABLE OF CONTENTS}

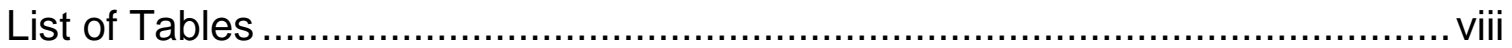

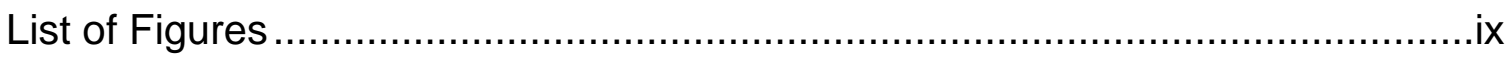

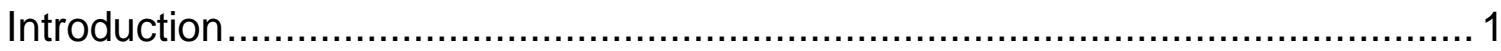

Related Research

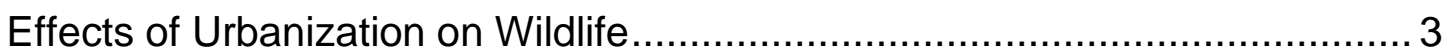

Abiotic changes to habitat structure .................................................. 4

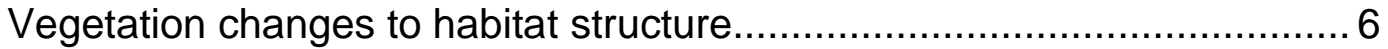

Changes to the biological community. .............................................. 7

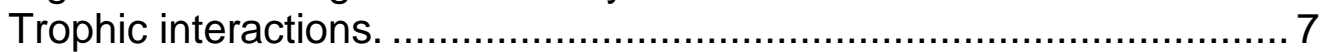

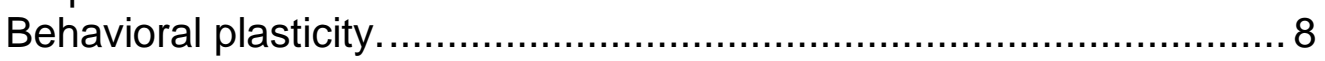

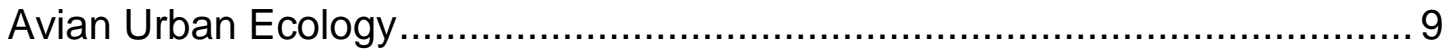

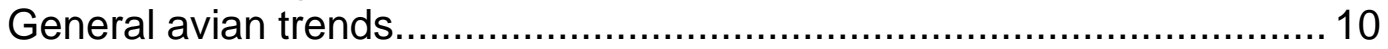

Important factors for avian success in cities. ......................................... 10

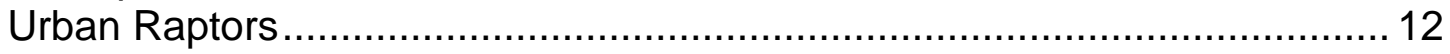

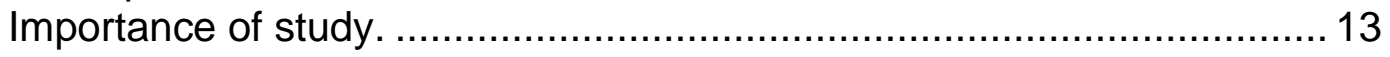

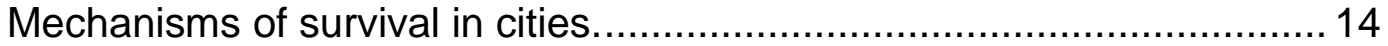

Urban Red-shouldered Hawks …...................................................... 16

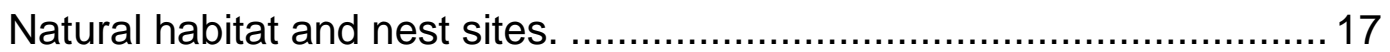

Natural diet and prey selection. ......................................................... 19

Mechanisms of urban success........................................................ 20

Habitat availability and diet flexibility. .......................................... 21

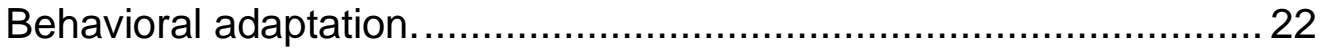

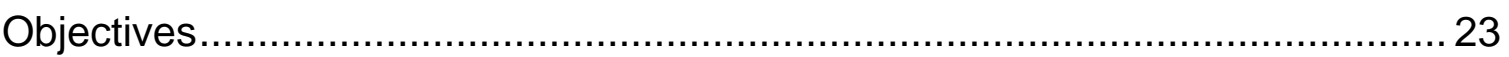

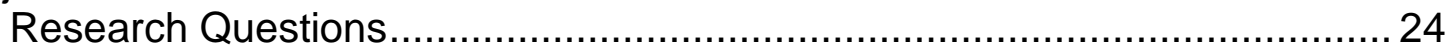

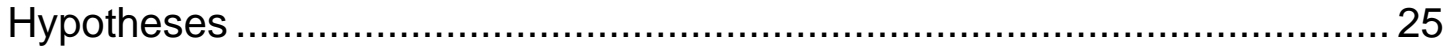

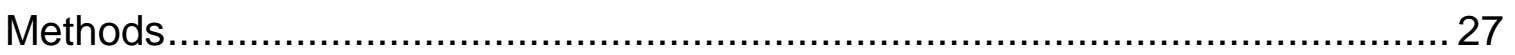

Study Sites and Target Population ........................................................ 27

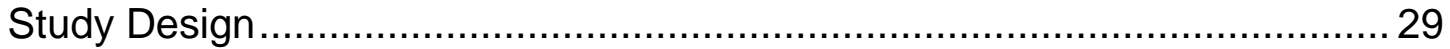

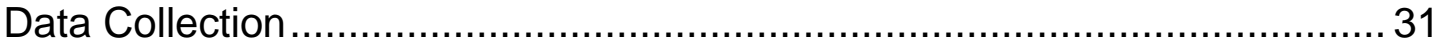

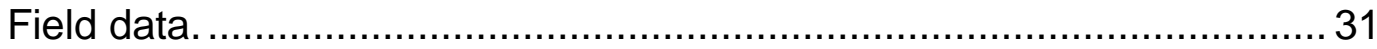

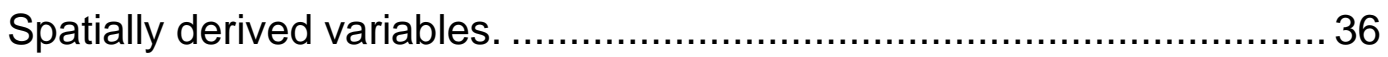

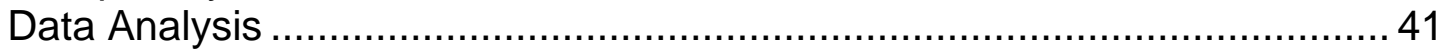

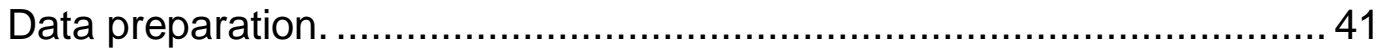

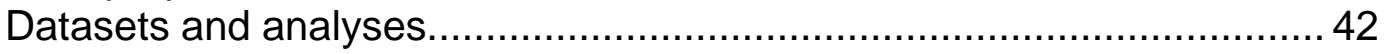

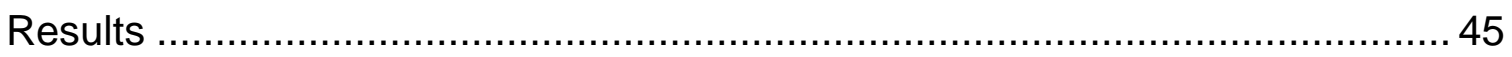

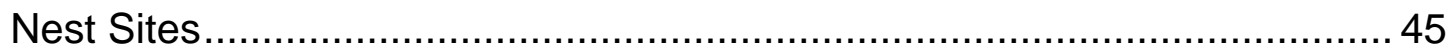


Diet Composition and Patterns......................................................... 47

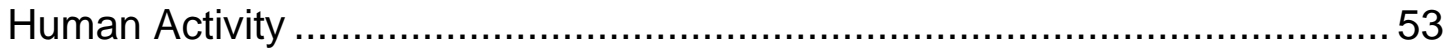

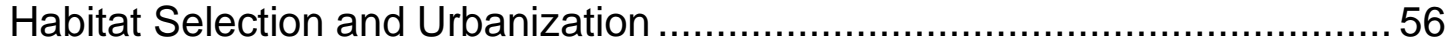

Variables Influencing Numbers of Chicks Fledged ........................................6. 61

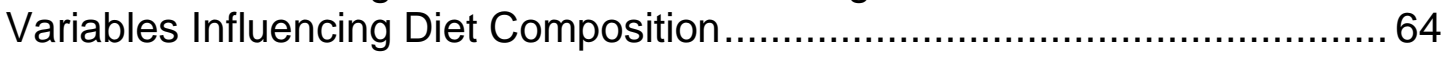

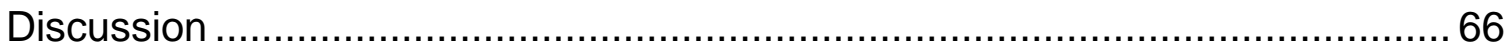

Recommendations for Management and Future Research ............................. 73

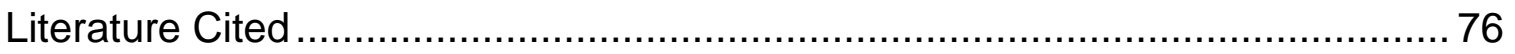

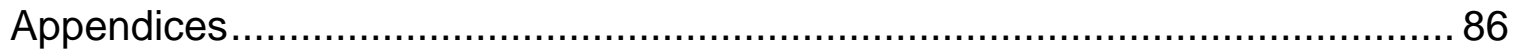

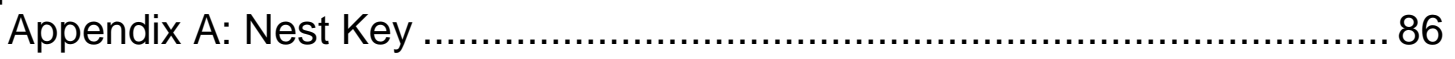

Appendix B: Complete List of Prey Species ........................................... 96

Appendix C: Complete List of External Activity ......................................... 98

Appendix D: National Land Cover Database Descriptions ......................... 102

Appendix E: R Code for Data Analysis..................................................... 105 


\section{LIST OF TABLES}

Table 1. $\quad$ Measured Field Variables................................................. 32

Table 2. Calculated Prey and External Activity Variables.................... 35

Table 3. $\quad$ Calculated Habitat Variables............................................... 36

Table 4. Determination of Nest Urbanization Category........................ 47

Table 5. Biomass and Delivery Frequency of Prey Classes in the Diets of Nesting Red-shouldered Hawks............................... 49

Table 6. External Activities Observed at Red-shouldered Hawk Nests.. 53

Table 7. Observed Red-shouldered Hawk Behavioral Responses to External Activities............................................................ 55

Table 8. Definitions of Behavioral Responses Exhibited by Redshouldered Hawks

Table 9. Pearson's Pairwise Correlation Matrix of Urbanization and Habitat Variables.

Table 10. Results of Principal Component Analysis............................. 61

Table 11. Matrix of Simple Linear Regressions of Diet Components and Habitat Metrics.

B12. Observed Prey Species Delivered to Red-shouldered Hawk Nests

C13. Observed External Activity at Red-shouldered Hawk Nests....

D14. Land Cover Types from the 2016 National Land Cover Database. 


\section{LIST OF FIGURES}

Figure 1. Location of study area within California................................ 27

Figure 2. Flowchart depicting the analyses performed on each dataset to answer the research questions and hypotheses..................

Figure 3. Nest locations of 19 red-shouldered hawk breeding pairs in Santa Clara County, CA........................................................

Figure 4. Percent biomass (A) and frequency (B) of prey classes in the diet of nesting red-shouldered hawks in Santa Clara County, CA

Figure 5. PCA of prey delivery frequency at 15 red-shouldered hawk nests (items/hr per nest)

Figure 6. PCA of prey biomass delivered to 15 red-shouldered hawk nests ( $\mathrm{g} / \mathrm{hr}$ per nest)

Figure 7. Human and natural activities per hour at each nest, averaged over the total hours observed at each nest.

Figure 8. PCA of habitat and urbanization variables at 19 redshouldered hawk nests in Santa Clara County, CA

Figure 9. Boxplot of the number of chicks fledged from all rural, suburban, and urban nests $(\mathrm{N}=19)$

Figure 10. Boxplot of the number of chicks fledged from successful rural, suburban, and urban nests $(\mathrm{N}=15)$. 


\section{Introduction}

Urbanization creates novel ecosystems, with many consequences to habitat structure and species community composition (Chace \& Walsh, 2006; Niemelä, 1999; Seress \& Liker, 2015). Birds provide a convenient taxon for studying ecological changes caused by urbanization, as they are relatively conspicuous and easy to observe. Birds are widely considered harbingers of ecological change and are often used as ecological monitors (Blair, 1996; Weber, Blank, \& Sloan, 2008). The diet of apex predators such as birds of prey may be different in urban and natural or rural environments, reflecting altered predator-prey interactions (Boal \& Dykstra, 2018; Estes \& Mannan, 2003). These changes are important to understand within the context of community structure and trophic dynamics in order to provide insight into urban food webs and species' long-term

persistence in urbanizing habitats. However, only some raptor species can thrive in urban environments; many species avoid developed areas (Boal \& Dykstra, 2018; Chace \& Walsh, 2006; Kettel, Gentle, Quinn, \& Yarnell, 2018). Habitat selection theory predicts that urban raptors are most successful when their natural habitat preferences match the physical structure of the urban environment (Boal, 2018; Chace \& Walsh, 2006). Based on prey selection theory, urban raptors with a naturally flexible diet will be more successful at taking advantage of the new or altered prey sources present in urban environments (Boal, 2018; Chace \& Walsh, 2006). Compatible habitat and adaptable diet preferences in turn influence what prey is available to a given 
raptor species, significantly affecting nesting success (Kettel et al., 2018;

Morrison, Gottlieb, \& Pias, 2016) and by extension affecting population dynamics and demography (Newton, 1979). Thus, the interaction between urban raptors and their prey is related to an understanding of urban raptor success as well as trophic dynamics and urban wildlife community structure. Studies of raptors in a variety of urbanized areas help land managers and conservationists understand how these birds may survive in areas with different prey availability (Boal \& Dykstra, 2018).

Santa Clara County, California is an ideal location for studying the effects of urbanization on raptors because of its unique combination of development gradients and biodiversity. The county contains dense urban centers, widely spaced suburban subdivisions, working agricultural lands, and everything in between. Development is interspersed with a wide variety of natural habitats, from annual grasslands to oak woodland to willow riparian corridors. This complex matrix provides ample habitat for both predatory and prey species. Avian diversity is high year-round, including several species of raptors such as the red-shouldered hawk (Bousman, 2007; Rottenborn, 2007). This presents an excellent opportunity to study the effects of urbanization on raptors and their prey communities within a relatively restricted geographic area. 


\section{Related Research}

\section{Effects of Urbanization on Wildlife}

Habitat loss, transformation, and degradation from human activity are prevalent and growing (Vitousek, Mooney, Lubchenco, \& Melillo, 1997), particularly as a result of the expansion of urban and suburban land uses (McKinney, 2002). Luniak (2004) proposed that urban and suburban settings create novel ecosystems and an "ecological vacuum" that attracts species to fill the ecological niches created by urban land uses. The phenomenon of animals successfully colonizing, living in, and reproducing naturally in urban environments is termed synurbanization (Luniak, 2004). Populations of species that have undergone this process are considered synurbic when the urban population density exceeds the rural population density (Francis \& Chadwick, 2012). Potentially synurbic species may include native species with local urban populations, species introduced or reintroduced by humans, and feral populations of escaped or released species (Luniak, 2004). Francis and Chadwick (2012) argued that because not all populations of a species will respond to urbanization in the same way, it is more accurate to refer to populations as synurbic, rather than whole species, unless the species is synurbic across its entire range. Understanding the patterns and mechanisms behind synurbanization can provide insight not only into the biology of individual species, but also into the ecology of the urban environment as an ecosystem of its own. Despite the apparent uniqueness of urban landscapes, Niemelä (1999) 
argued that is possible to study urban ecology with the same tools and theories developed for traditional ecological research.

Abiotic changes to habitat structure. Urbanization causes dramatic changes to the physical environment, completely restructuring the landscape through human activity. The severity of physical changes often progresses along an urban-rural gradient from natural or rural undeveloped land to increasingly altered environments associated with inner cities (Blair, 1996; Marzluff, Bowman, \& Donnelly, 2001; McDonnell \& Pickett, 1990; McKinney, 2002). Roads and buildings, perhaps the most prominent features of urbanized areas, replace natural land cover, fragment habitat, and directly increase human activity (Seress \& Liker, 2015). Habitat loss and fragmentation increase in proportion with increasing roads and buildings, degrading any remaining habitat into smaller patches with increasing proximity to the urban core (Marzluff et al., 2001; McKinney, 2002). Simultaneously, the area of impermeable surfaces increases (McKinney, 2002), affecting flows of surface water and reducing exposed soil available for vegetation. The built environment creates an urban heat island effect, where temperatures are higher in cities than in surrounding natural habitat, due to increased heat from energy use and retention of heat in building materials (Gil \& Brumm, 2014; McKinney, 2002; Seress \& Liker, 2015). Pollution also affects the urban environment, whether from light, noise, or chemicals (Gil \& Brumm, 2014; Seress \& Liker, 2015). In these settings, species composition is 
typically very restricted, although some species may be quite abundant (Chace \& Walsh, 2006; Seress \& Liker, 2015).

The patterns of these altered abiotic conditions may be highly variable over different landscapes and countries, presenting challenges to researchers attempting to quantify or describe the developed environment. The concept of the urban-rural gradient is frequently described as an orderly, linear transect from a dense urban downtown to low-development rural outskirts (McDonnell \& Pickett, 1990; McKinney, 2002). Although the concept of a gradient does accurately capture the continuous nature of development (Marzluff et al., 2001), Alberti, Botsford, and Cohen (2001) argued that this oversimplifies the urban structure. Most development takes a polycentric pattern, with multiple highdensity nodes connected by a highly variable patchwork of high- and low-density development and habitat patches (Alberti et al., 2001). In practice, Marzluff et al. (2001) noted that many researchers use discrete terms to describe specific portions of the gradient, such as "urban," "suburban," and "rural." The use of such terms may lead to confusion between different regions or cultures with different local vocabulary and make it difficult to compare studies. The validity of these terms is also often scale-dependent (Marzluff et al., 2001). Marzluff et al. (2001) recommended that discrete terms are most accurate at coarse landscape scales, while quantitative measures of urbanization, such as building density, are more appropriate for a more local scale of one to several kilometers. 
Quantitative measures also provide useful context to support or define the discrete terms used to describe the study area (Marzluff et al., 2001).

Vegetation changes to habitat structure. Vegetation patterns are likewise altered by urbanization. Seress and Liker (2015) reported that vegetative complexity generally decreases in urban areas, but Mills, Dunning, and Bates $(1989,1991)$ noted that in arid environments, vegetative complexity may increase instead. Urban vegetation often mimics a savannah structure, with less canopy cover and more ground cover than naturally forested habitats (Chace \& Walsh, 2006; McKinney, 2006). Urban habitats often maintain an early successional stage, due to constant disturbance by humans, such as mowing (Niemelä, 1999). Exotic and ornamental species, planted for human aesthetics and utility, also affect urban landscapes by causing some urban areas to have higher plant species richness than the surrounding environments (Chace \& Walsh, 2006; McKinney, 2006; Niemelä, 1999). Reduced vegetative biomass and complexity leads to reduced natural food availability for many animals, but anthropogenic sources can provide increased high-quality food sources for others such as rats and granivorous songbirds (Guiry \& Buckley, 2018; Seress \& Liker, 2015). Shochat, Warren, Faeth, Mclntyre, \& Hope (2006) suggested that the combination of vegetation management and anthropogenic food sources cause cities to act as "pseudo-tropical bubbles," where resource seasonality and thermal fluctuations are reduced regardless of latitude. 
Changes to the biological community. Since urbanization has such drastic effects on habitat structure, it is unsurprising that animal communities also differ along the urban-rural gradient. Blair (1996) described species as "urban avoiders," "urban exploiters," or "suburban adaptable," depending on how populations of the species respond to urbanization. Overall loss of vegetation often leads to loss of animal diversity (McKinney, 2002). Declines in both invertebrate and vertebrate species richness from the rural to urban environments is well-documented (Blair, 1996; Chace \& Walsh, 2006; McKinney, 2002). Non-native species tend to increase in urban environments, potentially outcompeting remnant native species (McKinney, 2002; Niemelä, 1999). Urban areas tend to have species compositions more similar to other urban areas than the surrounding natural habitat, a process known as biotic homogenization (Blair, 2001; McKinney, 2006; Seress \& Liker, 2015).

Trophic interactions. Community interactions, particularly those between predator and prey, are affected by changes in community composition associated with urbanization. Changes in species composition of both predators and prey alters the feeding dynamics in urban systems (Fischer, Cleeton, Lyons, \& Miller, 2012). Decreases in large mammalian predators in urban areas can cause the ecological release of smaller mesopredators, such as feral cats, raccoons, and opossums (Bolger, 2001; Chace \& Walsh, 2006; Fischer et al., 2012). Fischer et al. (2012) noted that although overall predator numbers increase in urban environments, predation rates on prey populations decrease, creating a 
predation paradox. Abundance of synurbic prey species may provide an overabundance of prey for urban predators, reducing the effects of predation (Fischer et al., 2012). Alternatively, Seress and Liker (2015) suggested that urban predators may rely more heavily on anthropogenic food sources, reducing predation pressure on prey species. Human activity can also affect overall community composition by influencing the availability of hunting and foraging areas, based on human disturbance patterns such as recreational park usage (Chace \& Walsh, 2006). Both top-down and bottom-up control likely play a role in urban food webs (Shochat et al., 2006).

Behavioral plasticity. Urban-dwelling animals must have some degree of adaptation to survive the physical and biological challenges presented by the urban environment. Luniak (2004) suggested that prerequisites for synurbanization include generalist preferences in both diet and habitat, along with demographic and behavioral plasticity. Urban animal populations may exhibit higher population densities, reduced migratory behavior, extended breeding seasons, greater longevity, higher winter survival rates, prolonged circadian activity, changes in nesting habits, changes in feeding behavior, habituation to people, and increased intraspecific aggression (Luniak, 2004). Sol, Lapiedra, \& Gonzalez-Lagos (2013) argued that these behavioral changes affect all stages of synurbanization, from arrival in urban areas, to establishment (foraging, predator avoidance, adjustment to human activity, communication, and habitat use), to long-term population increase. Given this extensive list of 
potential behavioral modifications, anthropogenic ecosystems are increasingly recognized as valuable study systems for animal adaptation mechanisms (Luniak, 2004; Marzluff, 2017). Although behavioral changes have been welldocumented in the literature, it is unclear if individual plasticity, filtering, or evolutionary response is the causal mechanism (Sol et al., 2013).

\section{Avian Urban Ecology}

Birds are excellent models for studying urban ecology, as they are both easily observable and conveniently abundant in urban areas throughout the world. Research in urban avian ecology has expanded exponentially in the past forty years, with over a thousand studies in the past decade alone (Marzluff, 2017; Marzluff et al., 2001). Marzluff et al. (2001) found that as of the year 2000, most studies of avian ecology were one- to two-year correlational studies describing patterns of bird occurrence and abundance in urban settings, mostly in the United States and northern Europe. By 2015, research had expanded into other parts of the globe, particularly to Latin America and Asia (Marzluff, 2017). Marzluff (2017) found that studies became increasingly focused on mechanistic processes that shape avian communities and populations, such as evolutionary processes and behavioral adaptation, as well as interactions between humans and birds, such as bird feeding. Review and meta-analysis papers also increased, demonstrating the growth of the field (Marzluff, 2017). More studies were of longer duration, up to a decade or more in length, though such long-term studies were still not common (Marzluff, 2017). 
General avian trends. Several overall trends in the patterns of avian abundance and diversity within urban environments have been identified from past research. In moving along an urban gradient, the most urban areas tend to have the greatest avian biomass but lowest species richness (Chase \& Walsh, 2006; Seress \& Liker, 2015). A peak of diversity often occurs in suburban environments with moderate levels of disturbance (Blair, 1996; Marzluff, 2017; Seress \& Liker, 2015). This observation is consistent with the intermediate disturbance hypothesis, which predicts that regular minor disturbance to an ecosystem, such as low-intensity suburban development, results in a more heterogeneous habitat, supporting a greater diversity of species (Blair, 1996; Seress \& Liker, 2015). Highly urbanized areas, however, tend to have very homogenous bird communities and fewer similarities to the bird community in the surrounding natural habitat (Chase \& Walsh, 2006; Marzluff, 2017). In general, birds that are granivores or omnivores do best in urban environments, as well as birds that are cavity nesters (Chase \& Walsh, 2006; Jokimäki, Suhonen, Jokimäki-Kaisanlahti, \& Carbó-Ramírez, 2016; Seress \& Liker, 2015). Seress and Liker (2015) found that highly urban bird communities have relatively large proportions of non-native species, except in Europe, where Jokimäki et al. (2016) found that urban areas have proportions of non-native species similar to that of natural areas.

Important factors for avian success in cities. Food availability plays a large role in the survival and reproduction of urban birds. Marzluff (2001) 
identified supplemental food resources from anthropogenic sources as a primary benefit of urban living. For passerine (songbird) species, urban food sources from waste and intentional bird-feeding may improve the condition and survival of birds over the winter, leading to earlier egg-laying and possibly higher breeding densities (Chamberlain et al., 2009). However, Chamberlain et al. (2009) also found that the lack of natural foods may lead to lower productivity per nesting attempt and lower nestling weights. This is likely linked to the reduced abundance and diversity of nestling food (arthropods) in urban environments (Seress \& Liker, 2015).

Availability of vegetation for nesting and foraging also plays a key role in determining avian success in urban environments. Birds respond strongly to vegetation patterns, associating more strongly with native vegetation (Blair, 1996; Mills et al., 1989, 1991). Habitat patch size has a direct influence on bird populations, with larger areas and more complex vegetative structure supporting increased avian diversity (Marzluff, 2017). Decreased vegetation associated with urbanized areas also reduces nest site availability (Seress \& Liker, 2015).

There are also possible behavioral components affecting adaptation to urban life. Sol et al. (2013) reported behavioral differences between urban and rural conspecifics, suggesting adaptive behavioral changes. Many of the recognized synurbic behavioral adaptations, such as changes in reproductive habits, extended breeding seasons, and reduced migratory behavior, were first identified in birds (Gil \& Brumm, 2014; Luniak, 2004). Bonier, Martin, \& Wingfield (2007) 
suggested that ecological generalist species which are "pre-adapted" to a broad range of environmental conditions are more likely to survive in an urban environment. These species may be more exploratory and able to take advantage of new opportunities provided by urban environments (Bonier et al., 2007; Sol et al., 2013).

\section{Urban Raptors}

It might be expected that birds of prey, being apex predators with sensitivity to disturbance, would be poor candidates for the urban avian community, but this is not necessarily the case (Boal \& Dykstra, 2018; Chace \& Walsh, 2006; Seress \& Liker, 2015). Reviews of raptor-specific studies do not find any generalized raptor response to urbanization (Chace \& Walsh, 2006; Kettel et al., 2018; Seress \& Liker, 2015). Some species with compatible prey preferences and hunting styles consistently respond favorably to urban environments, such as peregrine falcons (Cade, Martell, Redig, Septon, \& Hordoff, 1996; Kettel et al., 2018) and Cooper's hawks (Rosenfield, Mannan, \& Milsap, 2018; White, Smith, Bassett, Brown, \& Ormsby, 2018). Other species with prey preferences and flight styles unsuited to the developed environment reliably avoid urban habitat, such as golden eagles (White et al., 2018) and ferruginous hawks (Boal, 2018). For several species, such as Eurasian kestrels (Kettel et al., 2018; Seress \& Liker, 2018) and tawny owls (Chace \& Walsh, 2006; Kettel et al., 2018), different studies report conflicting responses to urbanized environments. 
Additionally, not every species responds to urbanization in the same way in every city. For instance, Chace and Walsh (2006) noted that red-shouldered hawks in New Jersey actively avoid suburban areas, while in California, Rottenborn (2000) found this species successfully nesting in non-native trees associated with the urban matrix. Similarly, Boal (2018) noted that northern goshawks avoid urbanized areas in North America but are commonly found in urban areas in Europe and Japan. Thus, the demography of a population may vary depending on the urban gradient in question, the raptor's needs, regional variations in climate, and the surrounding habitat (Mannan \& Steidl, 2018). It is also possible that certain urban areas function as ecological traps for raptors, whereby raptors are attracted to an area but are unable to sustain a long-term population. Powerful owls in Australia are attracted to urban areas by abundant marsupial prey, yet they lack nesting cavities necessary for reproduction (Cooke, Hogan, Isaac, Weaving, \& White, 2018; Mannan \& Steidl, 2018). Likewise, though Eurasian kestrels nesting in Europe capture more bird prey than nonurban kestrels, they tend to have lower reproductive success due to nestling starvation (Kettel et al., 2018).

Importance of study. The presence of urban raptors has important implications for the urban ecosystem and for raptor conservation. Fischer et al. (2012) argued that urban predators have the potential to exert top-down influence in urban communities, altering trophic structures and prey species composition. Urban and suburban landscapes may provide habitat to support 
some raptors while simultaneously reducing habitat for other species. Many raptor populations are in decline, and the ability of some species to utilize urban landscapes provides an intriguing conservation opportunity. For species that fare especially well in urban environments, urban habitats can positively impact the local population of the species (Boal \& Dykstra, 2018; Stout \& Rosenfield, 2010). Peregrine falcons, for instance, have been introduced into cities worldwide, supplementing natural populations suffering detrimental effects from the pesticide DDT (Pagel et al., 2018; Luniak, 2004).

Mechanisms of survival in cities. Diet and prey availability play an important role in whether a raptor will colonize urban habitats, consistent with observations of other avian taxa. It is well-recognized that prey availability has a strong influence on breeding rates and population density of raptors (Newton, 1979). Urban areas are believed to contain higher densities of avian prey compared to natural habitats (Chace \& Walsh, 2006), and thus raptors that consume avian prey generally respond favorably to urbanization (Dykstra, 2018; Kettel et al., 2018; Seress \& Liker, 2015). Examples include Cooper's hawks (Estes \& Mannan, 2003), northern goshawks (Rutz, Whittingham, \& Newton, 2006), and peregrine falcons (Kettel et al., 2018). Alternatively, Boal (2018) and Evans, Chamberlain, Hatchwell, Gregory, and Gaston (2011) found that generalist raptors with a wide diet breadth also appear to respond favorably, due to their ability to consume a variety of prey items. Examples include burrowing 
owls (Trulio \& Higgins, 2012) and red-shouldered hawks (Bloom \& McCrary, 1996; Dykstra, Hays, Simon, \& Daniel, 2003).

Habitat structure and land cover also likely play a significant role, particularly with regard to the type of vegetation available within the urban matrix (Marzluff, 2017; Morrison et al., 2016; Rullman \& Marzluff, 2014). Morrison et al. (2016) found that while open green space alone does not constitute ideal habitat, some species, such as red-tailed hawks, can utilize even small patches of green space if perches and prey are available. Urban raptors often have smaller home ranges than their rural counterparts, suggesting high habitat quality in urban areas (Dykstra, 2018). Boal (2018) found that species that normally occupy open woodland and forest habitat, such as barred owls, tend to fare better in urban landscapes than those that normally occupy open prairie or grassland habitat, such as ferruginous hawks, suggesting that the urban structure provides familiar habitat for woodland species.

Nest site availability in the urban environment also affects urban raptor success. Chace and Walsh (2006) proposed that species which are able to use novel or manmade nesting substrates may be more successful than those species which are unable or unwilling to use urban nest sites. For example, ospreys utilize a variety of human structures, such as transmission towers (Bird, Varland, \& Negro, 1996; Chace \& Walsh, 2006), and peregrine falcons are wellknown for their affinity for skyscrapers and other manmade structures (Bird et al., 1996; Pagel et al., 2018). 
Lastly, evolutionary changes and behavioral flexibility play a role in allowing some species or populations to respond more favorably to urbanization, though little research has been done for raptors (Cava, Stewart, \& Rosenfield, 2012; Marzluff, 2017; Seress \& Liker, 2015). For instance, it has been shown that some species in urban environments shift their diets to include more avian prey, even if birds do not normally comprise a large component of the diet (Boal, 2018; Dykstra, 2018). Several studies note apparent behavioral changes in urban raptors, whereby urban populations show a higher tolerance for activity near nests and a reduced tendency to flush from the nest when approached, compared to their rural-nesting conspecifics (Bloom \& McCrary, 1996; Boal \& Mannan, 1999; Dykstra, 2018).

\section{Urban Red-shouldered Hawks}

The red-shouldered hawk (Buteo lineatus) is a medium-sized hawk endemic to North America that often lives successfully in urban environments (Bloom \& McCrary, 1996; Dykstra, Bloom, \& McCrary, 2018). Hull et al. (2008) identified five subspecies: B. I. elegans occurs along the Pacific coast of the United States and Mexico, B. I. lineatus in the mid-west and northeast United States and southeast Canada, B. I. alleni in the southeast United States, B. I. extimus in southern Florida, and B. I. texanus in central Texas. The species range is disjunct, with B. I. elegans physically separated from the other four subspecies by hundreds of miles of unsuitable habitat (Hull et al., 2008). Genetic analysis conducted by Hull et al. (2008) shows two distinct evolutionary lineages 
corresponding to the western and eastern populations, with no recent genetic overlap. Red-shouldered hawks are considered partial migrants, with northernmost hawks traveling south in winter (Dykstra, Hays, \& Crocoll, 2008). Juveniles disperse widely (Bloom, Scott, Papp, Thomas, \& Kidd, 2011).

Natural habitat and nest sites. The red-shouldered hawk is primarily a forest-dwelling raptor, but it is not dependent on any specific forest type. In Ohio, Dykstra, Hays, Daniel, \& Simon (2001) observed that red-shouldered hawks occupy native oak-hickory, beech-maple, and riparian sycamore forests. In lowa, Bednarz and Dinsmore (1982) found that the hawks are using floodplain forest with abundant habitat edges and numerous small hunting areas. In areas reclaimed from mountaintop mining in West Virginia, Balcerzak and Wood (2003) observed that hawks choose intact forested areas over grassland habitat, but they also use edge habitats associated with fragmented forest and shrub habitats. In southern California, Bloom, McCrary, and Gibson (1993) identified woodland as the most commonly chosen habitat, most frequently oak or willow.

In addition to forested habitat, red-shouldered hawks are highly associated with small water bodies and riparian corridors. Within both intact and fragmented forest in West Virginia, wetlands are a significant predictor of red-shouldered hawk presence (Balcerzak \& Wood, 2003). In southern Ohio, Dykstra, Daniel, Hays, and Simon (2001) reported that the number of small ponds in a given area is highly correlated with hawk abundance. In Massachusetts, Portnoy and Dodge (1979) observed red-shouldered hawks nesting only in riparian habitat 
within deciduous woodland. In southern California, increased sycamore and willow habitats within the territory (associated with wetter environments) decreases the overall home range size, suggesting higher habitat quality (Bloom et al., 1993).

Red-shouldered hawks are also adaptable regarding nesting sites. At least 40 tree species have been used as nest sites, suggesting that tree species is relatively unimportant (Bednarz \& Dinsmore, 1982). Red-shouldered hawks place nests in trees growing on level ground, below the tree canopy on large, sturdy support branches with canopy cover, either in the main trunk crotch or in a major branch crotch (Bednarz \& Dinsmore, 1982). Rottenborn (2000) reported that nest tree height and diameter are significantly associated with reproductive success, with taller, larger-diameter trees associated with successful nests. This suggests that large trees provide the most desirable nesting sites (Rottenborn, 2000).

Eastern red-shouldered hawks in Ohio nest almost exclusively in native trees, primarily sycamore, ash, and oak (Dykstra, Hays, Daniel, \& Simon, 2000). Rural hawks in Massachusetts likewise prefer mature deciduous forest, and place nests in the largest deciduous tree available in the territory (Portnoy \& Dodge, 1979). In contrast, Bloom and McCrary (1996) reported that western redshouldered hawks in southern California frequently nest in non-native trees such as eucalyptus (Eucalyptus spp.), fan palm (Washingtonia spp.), and deodar cedar (Cedrus deodara). In central California, Rottenborn (2000) observed that 
urban red-shouldered hawks also frequently select exotic trees for nesting, particularly eucalyptus (Eucalyptus spp.), even in riparian areas with native Fremont cottonwoods (Populus fremontii) and western sycamores (Platanus racemosa) available.

Natural diet and prey selection. Red-shouldered hawks are generalist predators, eating a wide variety of prey including small mammals, amphibians, reptiles, and occasional birds, fish, and invertebrates (Bloom et al., 1993; Dykstra et al., 2003). They are perch hunters, so their use of non-forest habitat may be limited by available hunting perches (Bloom et al., 1993). Diet can vary considerably based on geographic location, at both the regional and local territory scales. Strobel and Boal (2010) reported that diet for the eastern populations can be separated by latitude, with hawks in northern latitudes taking more mammalian prey, while hawks in southern latitudes take more amphibians; avian, reptilian, and invertebrate prey comprise similar proportions in the diets of both. Dykstra et al. (2003) found that red-shouldered hawks in southwestern Ohio typically take voles, mice, snakes (especially garter snakes), and frogs from the genus Rana, with the bulk of both numbers and biomass from small mammals. Hawks in riparian and upland nesting areas in Ohio can differ significantly in diet, with fewer invertebrates (earthworms) than expected at riparian nests (Dykstra et al., 2003). In northern Michigan, Craighead and Craighead (1956) reported that the breeding season diet consists of meadow mice, small to medium birds, garter snakes, frogs, and crawfish, while the winter 
diet consists almost exclusively of meadow mice. In Wisconsin, Welch (1987) observed a diet comprised primarily of mammals, followed by invertebrates, amphibians, birds, and fish. In Massachusetts, Portnoy and Dodge (1979) found that hawks prey most often on eastern chipmunks (Tamias striatus), along with other small mammals, reptiles, birds, frogs, and beetles. Southern hawks in Georgia and Missouri prey more on amphibians and reptiles (Howell \& Chapman, 1998; Strobel \& Boal, 2010). In Georgia, amphibians are the most frequently delivered prey item (particularly frogs), but reptiles and mammals contribute the most biomass, particularly eastern garter snakes and water snakes (Howell \& Chapman, 1998). In Texas and Arkansas, Strobel and Boal (2010) found that invertebrates comprise a significant portion of the diet. Western red-shouldered hawks in California consume mostly invertebrates and small mammals (Bloom \& McCrary, 1996; Snyder \& Wiley, 1976), along with small birds, lizards, small snakes, frogs, crayfish, and fish (Bloom et al., 1993).

Mechanisms of urban success. Given the adaptability of red-shouldered hawks with regard to habitat structure and diet, it is unsurprising that these raptors appear to be reasonably successful in urban environments. In a 19-year study in Ohio, Dykstra et al. (2018) determined that the nesting success of suburban and rural hawks are similar. In a 25 -year study in southern California, Bloom and McCrary (1996) found that nesting success of urban red-shouldered hawks exceeds that of birds in rural habitat in the same region, though methods differed from the Dykstra et al. (2018) study. In central California, Rottenborn 
(2000) found that nesting and fledging rates are significantly higher in exotic trees in urban areas compared to native trees. Several contributing factors have been identified as possible explanations for the urban success of this species.

Habitat availability and diet flexibility. Habitat and dietary flexibility may allow red-shouldered hawks to occupy urban habitats unsuitable for other raptor species. Bloom et al. (1993) found that compared to other buteo hawks, redshouldered hawks have unusually small home range needs, which allows them to use small, fragmented habitat patches. Bloom and McCrary (1996) observed that urban-nesting hawks also use isolated hunting patches that are disjunct from the nesting territory, thus allowing the hawks to take advantage of even smaller spaces. In Ohio, Dykstra, Hays, et al. (2001) found that red-shouldered hawks follow the urban raptor pattern of equally sized or smaller home ranges in urban habitats compared to non-urban habitats, suggesting abundant prey availability in urban environments. In California, smaller home ranges are associated with relatively more mesic environments (sycamore and willow woodlands) that contain more aquatic prey such as frogs, crayfish, and fish, suggesting that such environments provide more abundant prey for nesting hawks (Bloom et al., 1993).

Even with less abundant prey, however, red-shouldered hawks can adjust. Despite dietary differences between northern and southern populations of the eastern red-shouldered hawk, Strobel and Boal (2010) reported no apparent difference in reproductive productivity between the populations. Suburban hawks 
take prey typical of conspecifics in more natural environments (Bloom et al., 1993; Dykstra et al., 2003). Dykstra et al. (2018) reported anecdotal observations of several unusual foods consumed by red-shouldered hawks, including pizza, beans, compost scraps, tuna cat food, and koi. Dykstra, Hays, et al. (2001) also observed red-shouldered hawks hunting at bird feeders.

Behavioral adaptation. Behavioral flexibility may also be an important factor. Bloom and McCrary (1996) noted that urban hawks appear to have habituated to human activity, even directly below the nest tree, and do not flush from perches unless approached closely. Rottenborn (2000) found that the degree of urbanization has no effect on nest site selection in central California, suggesting that the availability of suitable nest trees is more limiting than the extent of human development. Bloom et al. (2011) suggested that the ability of red-shouldered hawks to disperse widely also contributes to their adaptability in urbanized environments and range expansions into new areas. 


\section{Objectives}

Urbanization causes dramatic changes to the natural environment, often with serious consequences to the biological community and trophic structure (Niemelä, 1999; Seress \& Liker, 2015). Raptors are important urban predators which reflect changes in urban prey availability and community structure (Boal \& Dykstra, 2018; Estes \& Mannan, 2003). Raptor species that occupy both urban and natural habitats can provide insight into differences in community structure and trophic dynamics between the two habitat types, with important consequences for urban biodiversity conservation. Yet, there is little research examining the interactions between different urban taxa and the resulting structure of urban biological communities, including urban food webs and trophic structures (Fischer et al., 2012; Shochat et al., 2006).

Not all raptor species thrive in urban environments, and research increasingly focuses on determining how these sensitive carnivorous species adjust to urban environments (Boal \& Dykstra, 2018). Although there are numerous studies on patterns of species occurrence and abundance along the urban gradient, research into the mechanisms driving these patterns is relatively sparse (Marzluff et al., 2001; Shochat et al., 2006). Prey community structure and prey availability are important contributing factors to evaluate.

Red-shouldered hawks are recognized as successful urban raptors, exemplifying many of the characteristics of synurbic species. Some populations of red-shouldered hawks have smaller home ranges in urban habitats compared 
to non-urban habitats, allowing for high urban population densities (Dykstra, Hays, et al., 2001), and the species displays flexibility in behavior, diet, and nesting habitat preferences (Bednarz \& Dinsmore, 1982; Bloom \& McCrary, 1996; Bloom et al., 1993; Dykstra et al., 2018; Rottenborn, 2000). Thus, redshouldered hawks are a model species for studying raptor response to urbanization and changes in prey community along the urban-rural gradient. This species has not been well-studied compared to many other raptors, particularly with respect to comparisons between urban and rural subpopulations. In particular, the literature is lacking in comparative studies on the diet of urban and rural red-shouldered hawks in the same geographic and temporal frame (Dykstra et al., 2018). The objective of this thesis research is to describe and analyze red-shouldered hawk nesting habitat choices and the resulting dietary composition in a range of developed and rural settings by assessing the following research questions and hypotheses.

\section{Research Questions}

RQ1. What is the prey composition of the diet of nesting red-shouldered hawks in Santa Clara County, California?

RQ2. Are there general patterns of prey composition that relate to the level of urbanization surrounding a nest?

RQ3. What level of human activity does each nest experience, and how does this activity affect red-shouldered hawk behavior? 
RQ4. Are there general patterns of habitat selection that can be described for nesting red-shouldered hawks in Santa Clara County, California?

\section{Hypotheses}

Ho1. Red-shouldered hawk diet (frequency and biomass of prey classes) will not correlate with the following habitat metrics:

- total road length

- distance to nearest building

- total building number

- distance to water

- riparian area

- open space landcover

- developed landcover

- forest landcover

- shrub/grassland landcover

- agricultural landcover

- aquatic habitat landcover

- impervious surface area

- tree canopy cover

- human activities per hour

- natural activities per hour

- all external activities per hour 
Ho2. Number of red-shouldered hawk chicks fledged will not correlate with the following habitat metrics:

- total road length

- distance to nearest building

- total building number

- distance to water

- riparian area

- open space landcover

- developed landcover

- forest landcover

- shrub/grassland landcover

- agricultural landcover

- aquatic habitat landcover

- impervious surface area

- tree canopy cover

- human activities per hour

- natural activities per hour

- all external activities per hour

$\mathrm{H}_{03}$. The number of red-shouldered hawk chicks fledged will not correlate with total prey delivery frequency per nest nor total prey biomass per nest. 


\section{Methods}

\section{Study Sites and Target Population}

The study area encompassed the Santa Clara Valley in northern Santa Clara County, California. Santa Clara County is in west-central California and is the southernmost of the nine counties surrounding the San Francisco Bay (Figure 1). The county covers approximately $3,341 \mathrm{~km}^{2}$ (U.S. Census Bureau, 2010) with an estimated human population of approximately 1,940,000 in 2017 (U.S. Census Bureau, 2017).

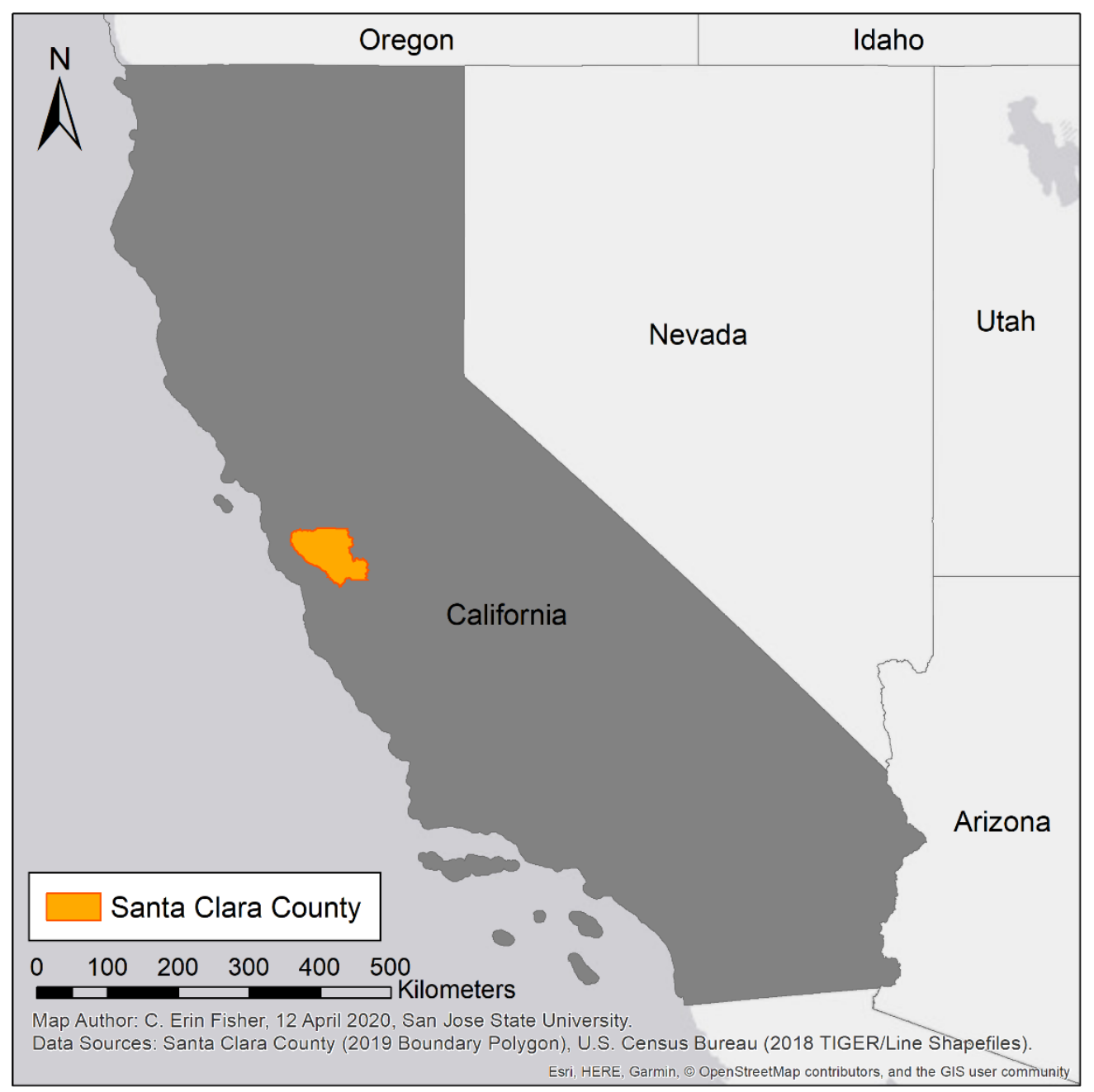

Figure 1. Location of study area within California. 
The Santa Clara Valley runs northwest to southeast for the length of the county, bordered by the Santa Cruz Mountains to the west and the Diablo Range to the east. The county contains a variety of specific ecoregions containing unique plant communities (Griffith et al., 2016; Holland \& Keil, 1995). Several rivers and creeks run through the valley, discharging into the southern end of the San Francisco Bay. The climate is Mediterranean, with mild wet winters and warm dry summers (Holland \& Keil, 1995). Elevation ranges from sea level at the southern end of the San Francisco Bay to over 1,280 m above sea level at the peak of Mount Hamilton in the Diablo Range (Bousman, 2007).

This study focused on breeding red-shouldered hawks with occupied nests during the 2019 breeding season. Red-shouldered hawks are year-round residents in California and regularly breed in Santa Clara County. Study efforts focused on the Santa Clara Valley area, as few red-shouldered hawks have been found nesting in the eastern portion of the county (Rottenborn, 2007).

Established residents may begin building nests as early as January, though typically nests are occupied from mid-April to mid-June (Rottenborn, 2007). The fledgling period, when offspring leave the nest, generally begins in early May, peaks in late May and early June, and gradually tapers off into July (Rottenborn, 2007).

Surveys for occupied nests began on March 1, 2019 to locate as many nests and nest-building pairs as possible, while deciduous trees were mostly bare and easy to survey. Diet observations, as determined by visually observed prey 
deliveries, occurred throughout the occupied nest stage, and ended with the fledging of young, when fledglings were counted. Although the fledglings continued to receive parental care after this time, the family groups were mobile and difficult to observe.

Individual study sites included the nest tree of a single pair of red-shouldered hawks, surrounded by a circular buffer zone of 121 ha. The circular buffer represented a zone of influence on the nest, based on the average annual home range for male red-shouldered hawks in southern California (Bloom \& McCrary, 1993). The zone of influence was used to quantify metrics measuring the degree of urbanization and habitat characteristics of the nest territory. Diet observations were made at each nest, when adults brought prey items to the nest for the chicks.

\section{Study Design}

The target sample size was at least 15 active nests within Santa Clara County. Occupied nests were located using publicly available eBird records, requests to the birding community via online listserv, word of mouth via local birders and community members, and site visits to suitable habitat locations to survey for nesting activity. Surveys for nesting hawks were not exhaustive and all nests used in the study were visible from public lands.

Once an occupied nest was found, its location was noted via visual landmarks and input into a geographic information system (GIS). No GPS locations were recorded in the field to avoid approaching nests. Permissions were requested 
and received by Santa Clara County Parks, City of San José, Town of Los Gatos, City of Palo Alto, City of Cupertino, and Stanford University to conduct observation sessions in their respective jurisdictions.

After nests were located, they were visited only briefly to assess the nesting stage and determine when chicks hatched. Once chicks had hatched, each nest was visited for one to seven sessions of approximately $3 \mathrm{hr}$ each for the duration of the nestling stage to collect data on diet and nest disturbances via direct visual observation. Every effort was made to visit each nest once per week; however, this was not always possible due to time constraints on researcher availability. The nestling stage begins at hatching and continues until fledging approximately six weeks later (Dykstra et al., 2008). Although more visits per nest might have increased the completeness of the diet for each nest, visits to a greater number of nests provided a higher sample size and widened the applicability of the results within the given time constraints (Dykstra et al., 2003).

Observation sessions were conducted during the morning (beginning before 10:00 PDT), afternoon (beginning 11:00-14:00 PDT), and evening (beginning after 14:00 PDT). Nests were visited over as many time periods (morning, afternoon, and evening) as possible and visits were divided between weekdays and weekends to capture as much variability in prey delivery and human activity as possible. Up to three nests were visited each field day, depending on researcher availability. No nest went unchecked for longer than 18 days prior to chicks hatching, a length of time which was dictated by estimated hatch date and 
researcher availability. No nest went unobserved for longer than 14 days once chicks were hatched, with sessions typically five to nine days apart. All nests were visited until the nest failed or chicks fledged. Nests were considered failures if the nest was physically destroyed or the behavior of the adults indicated abandonment in two consecutive visits.

After field data were collected, urbanization and habitat metrics (as listed in $\mathrm{H}_{0} 1$ and $\mathrm{H}_{0} 2$ ) were quantified within the 121-ha circular buffer zone of influence for each nest. All data on external activity (human and natural) were collected in the field. All other urbanization and habitat metrics were acquired via publicly accessible, remotely sensed data and processed in a GIS program.

\section{Data Collection}

Field data. Data collected in the field included site characteristics, prey deliveries, external activity around the nest, and numbers of chicks fledged (Table 1). External activities were defined as any activity in the immediate nest vicinity that was visible to, and might cause reaction from, a hawk on the nest. Fledglings were defined as young hawks that were either mobile and no longer confined to the nest or were at least 6 weeks old and developed enough to leave the nest on their own. Fledglings were counted during the last diet observation period when the young were approximately six weeks of age. 
Table 1.

Measured Field Variables

\begin{tabular}{cl}
\hline Variable measured & \multicolumn{1}{c}{ Data collected } \\
\hline Site Characteristics & Date of observation session \\
& Start \& end time \\
& Start \& end air temperature \\
& Start \& end wind speed \\
& Start cloud cover \\
& Number of chicks visible in nest \\
& Estimated chick age \\
& Nest condition \\
& Date/time of delivery \\
Prey Deliveries & Prey taxonomic class \\
& Prey species, if known \\
& Confidence in prey ID to lowest identified taxon \\
& Prey size \\
& Duration of feeding (min) \\
& Date/time of activity \\
& Category (human or natural) \\
& Cause of activity (hiker, dog, etc.) \\
& Number of individuals (\# hikers, \# dogs, etc.) \\
& Hawk behavioral response \\
Chicks Fledged & Number of fledglings at last observation session \\
\hline
\end{tabular}

Direct observation sessions were conducted from the ground at least $30 \mathrm{~m}$ from the nest tree with a direct view of the nest (Dykstra et al., 2003). I used a Vortex Viper HD 15-45x 65 mm spotting scope and REI 8x32 binoculars to obtain a clear view of the nest. A portable cloth blind was used to reduce disturbance if hawks appeared reactive to my presence. I used my car as a blind at nests where the surrounding land use made it appropriate to do so.

Site characteristics were collected within the first $30 \mathrm{~min}$ of my arrival at a nest. If the chicks were feeding upon arrival, I immediately began collecting prey data and did not proceed with any other task until the feeding event was 
complete, or the prey items confidently identified. Prey was identified to species whenever possible, and size and estimated age were assessed. External activities were typically not recorded during feeding events in order to focus on identification of prey items, leading to different total hours for prey observation and external activity observation. If prey was confidently identified immediately or activity frequency was low, I collected external activity data during feeding events. The time spent recording external activities was documented, as was the time, type, and quantity of activities observed during that time frame. Any hawk behaviors that occurred during or in response to an external activity were also recorded. Data on site characteristics were taken no more than 15 min before leaving a nest. All data were recorded electronically in the field using Google Sheets (Google LLC; Mountain View, CA) installed on an iPhone 6s (Apple Inc.; Cupertino, CA). Data were collected in offline mode and synced with the cloudbased Google Drive (Google LLC; Mountain View, CA) each evening upon returning from the field.

If a passerby asked a question or showed interest in my data collection, I answered questions honestly and quickly; however, no explanation was offered unless asked directly. This reduced public knowledge about the nest locations while still engaging and educating interested community members.

Prior to any data manipulations, field data were reviewed for quality assurance. Calculations were performed in Excel (Microsoft Corp.; Redmond, WA). For each nest, I calculated several metrics of prey delivery and external 
activity based on the data collected in the field (Table 2). For each prey class at each nest, I calculated the delivery frequency (per hour and per chick per hour) and biomass (per hour and per chick per hour). I also calculated the combined total prey frequency and combined total prey biomass (per hour and per chick per hour) for all prey items delivered to a given nest. Prey biomass was estimated from the identified species and recorded size of the item. Prey size was an indicator of prey age, which allowed for more accurate biomass estimation (Bielefeldt, Rosenfield, \& Papp, 1992). Species biomass of appropriate age, region, and season was taken from the established literature when possible, supplemented with regional field guides (Bielefeldt et al., 1992; Estes \& Mannan, 2003). Prey items that could not be identified to species were assigned estimated biomass based on visual observations and comparisons with prey size of known estimated mass (Cava et al., 2012). 
Table 2.

Calculated Prey and External Activity Variables

\begin{tabular}{|c|c|c|}
\hline Variable calculated & Units & Calculation per nest \\
\hline Frequency & items $/ \mathrm{hr}$ & $\begin{array}{l}\text { Total \# of individuals of a given prey } \\
\text { class divided by the total observation } \\
\text { hours }\end{array}$ \\
\hline $\begin{array}{l}\text { Frequency per } \\
\text { chick }\end{array}$ & items/chick/hr & $\begin{array}{l}\text { Total \# of individuals of a given prey } \\
\text { class divided by the \# of chicks fledged } \\
\text { divided by the total observation hours }\end{array}$ \\
\hline Biomass per hour & $\mathrm{g} / \mathrm{hr}$ & $\begin{array}{l}\text { Total grams of biomass of a given prey } \\
\text { class divided by the total observation } \\
\text { hours }\end{array}$ \\
\hline $\begin{array}{l}\text { Biomass per chick } \\
\text { per hour }\end{array}$ & g/chick/hr & $\begin{array}{l}\text { Total grams of biomass of a given prey } \\
\text { class divided by the \# of chicks fledged } \\
\text { divided by the total observation hours }\end{array}$ \\
\hline Total frequency & items/hr & $\begin{array}{l}\text { Total combined \# of individuals of all } \\
\text { prey classes divided by the total } \\
\text { observation hours }\end{array}$ \\
\hline $\begin{array}{l}\text { Total frequency } \\
\text { per chick }\end{array}$ & items/chick/hr & $\begin{array}{l}\text { Total combined \# of individuals of all } \\
\text { prey classes divided by the \# of chicks } \\
\text { fledged divided by the total observation } \\
\text { hours }\end{array}$ \\
\hline $\begin{array}{l}\text { Total biomass per } \\
\text { hour }\end{array}$ & $g / h r$ & $\begin{array}{l}\text { Total combined grams of biomass of all } \\
\text { prey classes divided by the total } \\
\text { observation hours }\end{array}$ \\
\hline $\begin{array}{l}\text { Total biomass per } \\
\text { chick per hour }\end{array}$ & g/chick/hr & $\begin{array}{l}\text { Total combined grams of biomass of all } \\
\text { prey classes divided by the \# of chicks } \\
\text { fledged divided by the total observation } \\
\text { hours }\end{array}$ \\
\hline $\begin{array}{l}\text { Human activity } \\
\text { frequency }\end{array}$ & $\begin{array}{l}\text { human } \\
\text { activities/hr }\end{array}$ & $\begin{array}{l}\text { Total \# of human activities divided by the } \\
\text { total observation hours for a given nest }\end{array}$ \\
\hline & $\begin{array}{c}\text { natural } \\
\text { activities/hr }\end{array}$ & $\begin{array}{l}\text { Total \# of natural activities divided by the } \\
\text { total observation hours }\end{array}$ \\
\hline $\begin{array}{l}\text { Total external } \\
\text { activity frequency }\end{array}$ & $\begin{array}{l}\text { external } \\
\text { activities/hr }\end{array}$ & $\begin{array}{l}\text { Total combined \# of human and natural } \\
\text { activities divided by the total observation } \\
\text { hours }\end{array}$ \\
\hline
\end{tabular}


Human, natural, and total external activity frequency were calculated for each nest. Each individual source of external activity was counted, rather than single events (potentially comprised of several individual sources at the same time). This captured the cumulative effect of a larger group of small activities (for instance, the effect of a single hiker compared to a large hiking group). Individual activity sources were grouped into broader categories for descriptive statistics.

Spatially derived variables. Seventeen other urbanization and habitat metrics were quantified for each nest (Table 3), using a combination of publicly available aerial imagery and GIS data from government agencies. All geospatial operations and calculations were performed in ArcMap 10.6.1 for Desktop (ESRI; Redlands, CA).

Table 3.

Calculated Habitat Variables

\begin{tabular}{|c|c|c|c|}
\hline Habitat variable & Variable code & Units & Calculation per nest buffer \\
\hline Total road length $^{a}$ & RD_LENGTH & $\mathrm{m}$ & $\begin{array}{l}\text { Sum length of all road } \\
\text { segments }\end{array}$ \\
\hline $\begin{array}{l}\text { Distance to nearest } \\
\text { building }{ }^{b}\end{array}$ & $\begin{array}{l}\text { DIST_TO } \\
\text { BLDG }\end{array}$ & $\mathrm{m}$ & $\begin{array}{l}\text { Distance to nearest } \\
\text { building }\end{array}$ \\
\hline $\begin{array}{l}\text { Total building } \\
\text { number }{ }^{b, c}\end{array}$ & BLDG_TOTAL & $\begin{array}{l}\text { \# of } \\
\text { bldgs }\end{array}$ & Total number of buildings \\
\hline Distance to water $\mathrm{d}, \mathrm{e}$ & DIST_TO_W & $\mathrm{m}$ & $\begin{array}{l}\text { Distance to nearest natural } \\
\text { water }\end{array}$ \\
\hline Riparian area ${ }^{d}$ & RIF & $\mathrm{m}^{2}$ & $\begin{array}{l}\text { Total area within } 100 \mathrm{~m} \text { of } \\
\text { a creek or river }\end{array}$ \\
\hline $\begin{array}{l}\text { Open space } \\
\text { landcover f,g }\end{array}$ & OPSP & $\mathrm{m}^{2}$ & $\begin{array}{l}\text { Sum area of all developed } \\
\text { open space }\end{array}$ \\
\hline $\begin{array}{l}\text { Developed } \\
\text { landcover }{ }^{\mathrm{f}, \mathrm{g}}\end{array}$ & ALL_DEV & $\mathrm{m}^{2}$ & $\begin{array}{l}\text { Sum area of low, medium, } \\
\text { and high intensity human } \\
\text { development }\end{array}$ \\
\hline Forest landcc & FOREST & $\mathrm{m}^{2}$ & $\begin{array}{l}\text { Sum area of evergreen and } \\
\text { mixed forest }\end{array}$ \\
\hline
\end{tabular}




\begin{tabular}{|c|c|c|c|}
\hline $\begin{array}{l}\text { Shrub/grassland } \\
\text { landcover }{ }^{f, g}\end{array}$ & SHR_GRS & $\mathrm{m}^{2}$ & $\begin{array}{l}\text { Sum area of shrub/scrub } \\
\text { and grassland/herbaceous } \\
\text { cover }\end{array}$ \\
\hline $\begin{array}{l}\text { Agricultural } \\
\text { landcover } \mathrm{f,g}\end{array}$ & AGRI & $\mathrm{m}^{2}$ & $\begin{array}{l}\text { Sum area of pasture/hay } \\
\text { and cultivated crops }\end{array}$ \\
\hline Aquatic landcover ${ }^{\mathrm{f}, \mathrm{g}}$ & AQUA & $\mathrm{m}^{2}$ & $\begin{array}{l}\text { Sum area of woody } \\
\text { wetlands, emergent } \\
\text { herbaceous wetlands, and } \\
\text { open water }\end{array}$ \\
\hline $\begin{array}{l}\text { Impervious surface } \\
\text { area }{ }^{g, h}\end{array}$ & IMPERV & $\mathrm{m}^{2}$ & $\begin{array}{l}\text { Surface area covered by } \\
\text { impervious surfaces }\end{array}$ \\
\hline Tree canopy cover g,i & CANOPY & $\mathrm{m}^{2}$ & $\begin{array}{l}\text { Surface area covered by } \\
\text { tree canopy }\end{array}$ \\
\hline
\end{tabular}

Note. All landcovers are defined by the National Land Cover Database (NLCD). Appendix D contains detailed definitions of landcovers from the NLCD.

a Santa Clara County Streets (Santa Clara County, 2018). Original projection WGS 84 (DD). ' Santa Clara County Orthoimagery 2018 (Santa Clara County, 2019b). Original projection WGS 1984 Web Mercator Auxiliary Sphere. ${ }^{c}$ Open Street Map Basemap, accessed through ArcGIS 10.6.1 for Desktop. d Santa Clara County Creeks, containing creeks and canals in Santa Clara County (Santa Clara Valley Water District, 2019a). Original projection GCS WGS 1984. e Santa Clara County Water Bodies, containing water bodies in and around Santa Clara County, including reservoirs, lakes, percolation ponds, and salt ponds (Santa Clara Valley Water District, 2019b). Original projection GCS WGS 1984. ${ }^{f}$ NLCD: Landcover 2016 from the Multi-Resolution Land Characteristics Consortium (MRLC, 2019a). Original projection Albers Conical Equal Area. g Santa Clara County Boundary (Santa Clara County, 2019a). Original projection GCS WGS 1984. ${ }^{\mathrm{h}}$ NLCD: Imperviousness 2016 (MRLC, 2019b). Original projection Albers Conical Equal Area. ' NLCD: Tree Canopy 2016 (MRLC, 2019c). Original projection Albers Conical Equal Area.

Orthoimagery of Santa Clara County was used as the base map layer (Santa Clara County, 2019b). This imagery only displayed in projected coordinate system WGS 1984 Web Mercator Auxiliary Sphere, so all subsequent spatial data were projected to match, as necessary. For each nest located during the 2019 breeding season, a single point location was created in a geodatabase 
feature class (named RSHA_NESTS_2019) by referencing the orthoimagery and ground-truthing on-site. A circular zone with a 620-m radius (approximately 121ha circle) was drawn around each nest site using the "Buffer" tool with the nest site as the center point and saved as a separate geodatabase feature class (named NESTS_BUFFER620m). The shapefile of the Santa Clara County boundary (Santa Clara County, 2019a) was imported and used to clip raster files to improve processing time. Output tables from ArcMap were imported into Microsoft Excel for further processing as described below.

Raster datasets for landcover types, imperviousness, and tree canopy from the National Land Cover Database (NLCD) were obtained from the MultiResolution Land Characteristics Consortium (MRLC) at a 30-m x 30-m cell resolution (MRLC, 2019a, 2019b, 2019c). For each of the three files, I first preselected the County boundary polygon. I then used the "Clip" tool from the Image Analysis window to clip the full-size raster to the size of the pre-selected County boundary. Each raster file was then visually compared (by adjusting the layer transparency) to the underlying orthoimagery to ensure a reasonable match to on-the-ground characteristics. Minor overlaps in nest buffers, while not biologically relevant, did require consideration in spatial processing as overlapped raster areas would not tabulate correctly. To overcome this, I split the nest buffers into two arbitrary but non-overlapping groups and processed each group separately. I used the "Tabulate Area" tool from the Zonal Toolkit (Spatial Analyst Tools) to input the file NESTS_BUFFER620m (with a pre-selected group 
that indicated within which buffers the raster had to be tabulated), the landcover raster file, and output table file name and location. When the output table was created, I used the "Add Field" function to add a field in which the values were summed to ensure accurate tabulation of the area (approximately $121 \mathrm{ha}$, depending on how the raster cells were arranged at buffer edges). This same process was repeated with the imperviousness and tree canopy raster, but the sum calculation to check for accuracy was completed in Excel due to the size of the output tables.

In Excel, raster data were further processed for use. Landcover types determined to be of similar type and habitat value for hawks were combined. For instance, "pasture/hay" and "cultivated crops" were combined into a single agricultural landcover; "evergreen forest" and "mixed forest" were combined into a single forest landcover; "woody wetlands," "emergent herbaceous wetlands," and "open water" were combined into a single aquatic habitat landcover; and "shrub/scrub" and "grassland/herbaceous" were combined into a single shrub/grassland landcover.

As urbanization was a primary focus of this research, development landcovers of low, medium, and high intensity were combined into a single developed landcover variable. For imperviousness and tree canopy, the total area of coverage was calculated using the output table from ArcMap. Output information consisted of total square meters of coverage within each percent coverage possible (for instance, $1800 \mathrm{~m}^{2}$ covered with $50 \%$ tree canopy cover). 
The total coverage was calculated as the percent coverage multiplied by the square meters of that percentage (for instance, $1800 \mathrm{~m}^{2} \times 50 \%$ coverage $=900$ $\mathrm{m}^{2}$ of actual tree canopy coverage). This calculation was done for all output values and summed for imperviousness and tree canopy cover within each nest buffer.

For road length, I used a vector shapefile of Santa Clara County Streets (Santa Clara County, 2018). I used the "Intersect" tool on the Streets file and NESTS_BUFFER620m (no selection, as vector data tabulated correctly with overlaps), and saved the output as a new geodatabase file. I then ran the "Tabulate Intersection" tool from the Statistics Toolkit (Analysis Tools) on NESTS_BUFFER620m as zone features (Zone Field = Object ID, Nest_Code) and the new geodatabase file as the input class features. The resultant output table had total length of road segments summed for each nest buffer.

To create riparian buffer zones, I used a vector shapefile of Santa Clara County Creeks (Santa Clara Valley Water District, 2019a). I created a 100-m buffer around all waterways with the "Buffer" tool (dissolve type = all), based on the riparian distance used by Rottenborn (2000). I then used the "Intersect" tool to intersect the riparian areas to nest buffers for easier rendering and analysis. Riparian area for each nest was calculated using the "Dissolve" tool (Dissolve Field $=$ nest code, Statistics Field $=$ area summed $)$.

For distance measurements (distance to nearest building, distance to nearest water source), the "Measure" tool was used in ArcMap. The nest served as the 
anchor point, and measurements were made to the nearest meter. An additional vector shapefile with Santa Clara County water bodies (Santa Clara Valley Water District, 2019b) was imported to accurately determine if the nearest water source was a water body or creek. For distance to water source, the "Snap" feature was enabled to accurately determine the distance between the two features. For distance to nearest building, measurements were determined visually, using the orthoimagery to locate nearby buildings. Distance was measured from the nest location to the nearest building wall. Due to the inherent uncertainty of water extent (such as creek banks and ephemeral ponds) and error associated with using orthoimagery, 1-m precision was considered adequate for distance measurements.

The number of buildings within each nest buffer was determined using a combination of the OpenStreetMap Basemap provided within the ArcMap program and the orthoimagery. OpenStreetMap provided clear defining building footprints, and orthoimagery was used to verify building placement and existence. Buildings were counted manually. If at least half of a building fell within the nest buffer by visual estimation, the building was included in the building count.

\section{Data Analysis}

Data preparation. Given the large number of habitat and urbanization variables I measured, I used pairwise Pearson's correlation analyses to identify highly correlated variables (SPSS Statistics Version 26, IBM; Armonk, NY). 
When pairs of variables with relatively high correlation between them $(0.40$ or greater) were identified, only one of the variables was selected to be used as a predictor.

Datasets and analyses. All data analyses were accomplished using $\mathrm{R}$ (version 3.6.3, The R Foundation) and RStudio (version 1.2.5033, RStudio, Inc.; Boston, MA). R packages "FactoMineR," "factoextra," and "plotrix" were used. R code for all analyses can be found in Appendix E. Descriptive measures were calculated in Excel.

Three datasets were used to address my research questions and hypotheses, each a subset of the prior dataset (Figure 2). The total number of breeding pairs were all pairs found with a confirmed nest location in the 2019 breeding season. I used principal component analysis (PCA) to examine habitat selection patterns among nests and Spearman rank correlation to examine relationships among the number of chicks fledged and habitat/urbanization metrics. If chicks were successfully hatched, diet and external activity observations were taken as described in the methods above. Nests with at least three observation sessions that successfully fledged chicks were considered to have adequate data for inclusion in a PCA of diet composition and parametric statistical analyses between diet metrics and habitat/urbanization metrics. Diet metrics with nonzero values for at least half of observed nests were considered to have adequate data for inclusion in statistical analyses. Prey data were log-transformed when necessary to conform to assumptions of normality. 
Total Number of Breeding Pairs

- RQ4: PCA - habitat selection

- $\mathrm{H}_{0}$ 2: Spearman Rank Correlations - chicks fledged \& urban/habitat metrics

- $\mathrm{H}_{0}$ 2: Kruskal-Wallis Test - chicks fledged by urbanization categories

- RQ1: Descriptive - prey composition of diet

- RQ3: Descriptive - human activities (quantity and effects)

Number of Pairs with No Chicks Hatched

Number of Pairs Observed 3 or More Times (Chicks Fledged)

- RQ2: PCA - prey composition of diet

- $\mathrm{H}_{0}$ 1: Linear Regressions - prey composition \& urban/habitat metrics

- $\mathrm{H}_{0}$ 3: Spearman Rank Correlations - chicks fledged \& total biomass, total frequency

Figure 2. Flowchart depicting the analyses performed on each dataset to answer the research questions and hypotheses.

For each nest, an urbanization category—urban, suburban, or rural—was assigned using a combination of three metrics based on a categorization system by Marzluff et al. (2001). Impervious surface was calculated as the IMPERV variable, expressed as a percentage. Building density was calculated as the BLDG_TOTAL variable divided by the number of hectares within the nest buffer. Total developed landcover was calculated as the ALL_DEV variable, expressed as a percentage. Impervious surface and total developed landcover were considered rural at $0-25 \%$ cover, suburban at $25-50 \%$ cover, and urban at $>50 \%$ cover. Building density was considered rural at 0-2.5 bldgs/ha, suburban at 2.5$10 \mathrm{bldgs} / \mathrm{ha}$, and urban at $>10 \mathrm{bldgs} / \mathrm{ha}$. If a nest fell into the same urbanization category by at least two criteria, then the nest was categorized as such. If a nest fell into all three urbanization categories using the three criteria, then the nest 
was categorized as suburban. The three urbanization categories were used to visually group nests in the PCAs and to analyze the relationships among levels of urbanization and number of chicks fledged using a Kruskal-Wallis test.

This study design was approved by San José State University's Institutional Animal Care and Use Committee as an observational study (Protocol \#: 2019-A). 


\section{Results}

\section{Nest Sites}

I located a total of 19 red-shouldered hawk breeding pairs during the 2019 breeding season (Figure 3, Appendix A). One urban pair consisted of a subadult female with an adult male; the remainder were pairs between adult hawks.

Eighteen of these pairs were found at the beginning of the breeding season, with one additional pair found partway through the season. Habitat analyses were conducted using all of these nests.

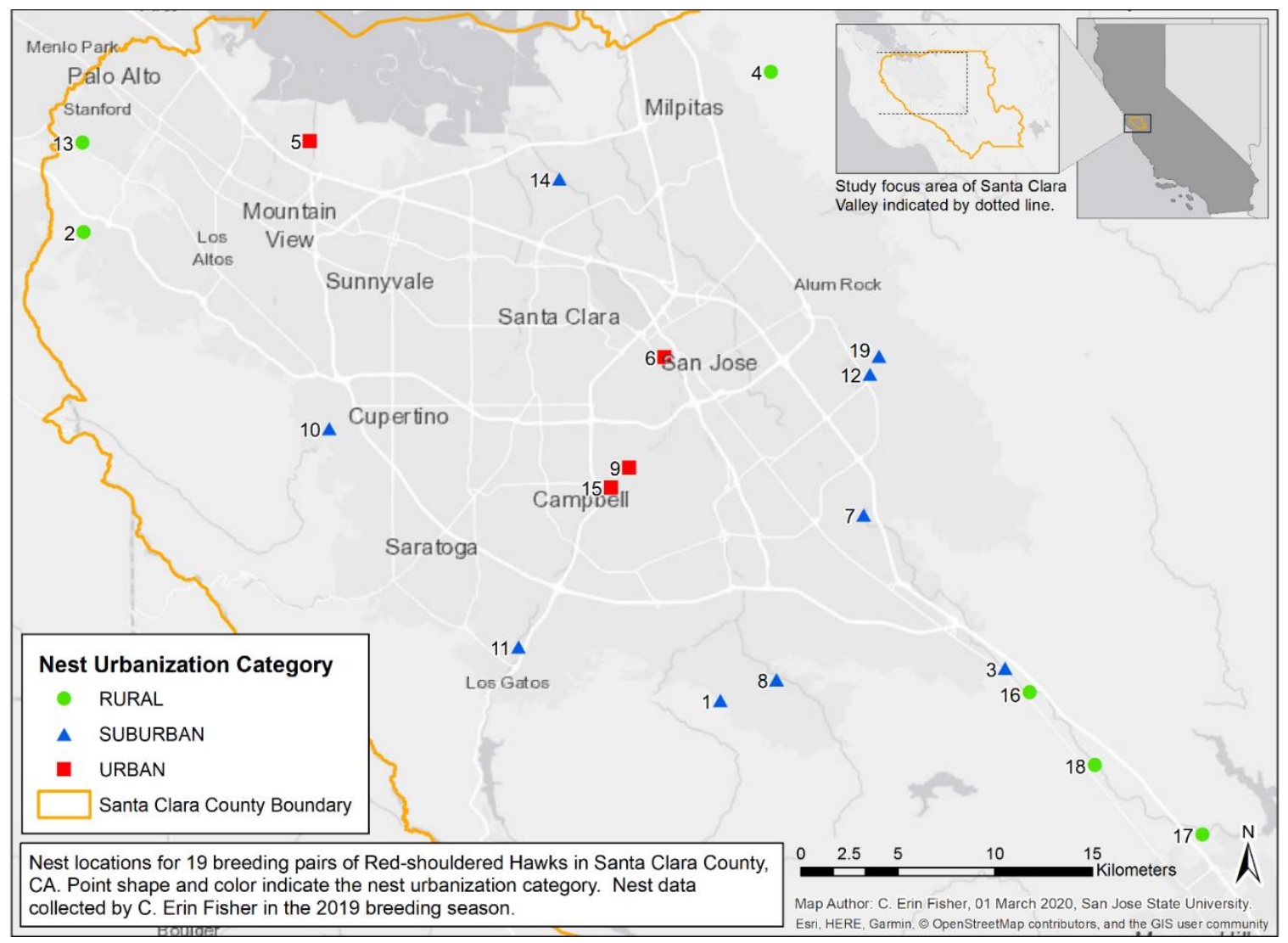

Figure 3. Nest locations of 19 red-shouldered hawk breeding pairs in Santa Clara County, CA. 
Sixteen pairs hatched chicks but, at one nest where chicks hatched, I accomplished just one observation session before the chicks disappeared. Data from this nest were included in the qualitative analyses of prey type and external activity but could not be included in statistical analyses using prey delivery or human activity metrics.

Fifteen pairs were observed for three to seven sessions, or an average time of $3.0 \mathrm{hr}$ per session, and these 15 nests were included in all statistical analyses. The total observation time at each nest over the full season ranged from 8.6 to $23.1 \mathrm{hr}$, with an average of $14.5 \mathrm{hr}$ per nest. The 15 pairs fledged between one and three chicks each, for a total of 29 chicks fledged over all nests observed. A mean of $1.93 \pm 0.704( \pm S D)$ chicks were fledged per successful nest $(N=15)$ and a mean of $1.53 \pm 1.020( \pm S D)$ chicks were fledged per breeding pair $(N=19)$.

Each nest was categorized as urban, suburban, or rural based on three urbanization metrics describing the nest buffer, as described in the methods. Six nests were rural, nine were suburban, and four were urban (Table 4). Four nests, all rural, were categorized the same way across all three metrics, while only two had one of each category across all three metrics. 
Table 4.

Determination of Nest Urbanization Category

\begin{tabular}{cccccccc}
\hline \multirow{2}{*}{$\begin{array}{c}\text { Nest } \\
\text { ID }\end{array}$} & \multicolumn{2}{c}{$\begin{array}{c}\text { Impervious } \\
\text { surface }\end{array}$} & \multicolumn{2}{c}{ Building density } & \multicolumn{2}{c}{$\begin{array}{c}\text { Total developed } \\
\text { landcover }\end{array}$} & $\begin{array}{c}\text { Urbanization } \\
\text { category }\end{array}$ \\
\cline { 2 - 6 } & $\%$ & $\mathrm{R} / \mathrm{S} / \mathrm{U}$ & bldgs/ha & $\mathrm{R} / \mathrm{S} / \mathrm{U}$ & $\%$ & $\mathrm{R} / \mathrm{S} / \mathrm{U}$ & $\mathrm{S}$ \\
\hline 1 & 24.4 & $\mathrm{R}$ & 3.01 & $\mathrm{~S}$ & 48.5 & $\mathrm{~S}$ & $\mathrm{R}$ \\
2 & 1.2 & $\mathrm{R}$ & 0.06 & $\mathrm{R}$ & 1.1 & $\mathrm{R}$ & $\mathrm{S}$ \\
3 & 32.7 & $\mathrm{~S}$ & 0.05 & $\mathrm{R}$ & 49.7 & $\mathrm{~S}$ & $\mathrm{R}$ \\
4 & 1.6 & $\mathrm{R}$ & 0.00 & $\mathrm{R}$ & 1.1 & $\mathrm{R}$ & $\mathrm{U}$ \\
5 & 50.7 & $\mathrm{U}$ & 1.53 & $\mathrm{R}$ & 81.3 & $\mathrm{U}$ & $\mathrm{U}$ \\
6 & 56.2 & $\mathrm{U}$ & 0.46 & $\mathrm{R}$ & 74.2 & $\mathrm{U}$ & $\mathrm{S}$ \\
7 & 34.9 & $\mathrm{~S}$ & 2.85 & $\mathrm{~S}$ & 61.9 & $\mathrm{U}$ & $\mathrm{S}$ \\
8 & 38.7 & $\mathrm{~S}$ & 3.77 & $\mathrm{~S}$ & 78.9 & $\mathrm{U}$ & $\mathrm{U}$ \\
9 & 50.7 & $\mathrm{U}$ & 5.11 & $\mathrm{~S}$ & 90.7 & $\mathrm{U}$ & $\mathrm{S}$ \\
10 & 35.6 & $\mathrm{~S}$ & 3.95 & $\mathrm{~S}$ & 65.5 & $\mathrm{U}$ & $\mathrm{S}$ \\
11 & 38.0 & $\mathrm{~S}$ & 3.16 & $\mathrm{~S}$ & 66.1 & $\mathrm{U}$ & $\mathrm{S}$ \\
12 & 40.9 & $\mathrm{~S}$ & 1.08 & $\mathrm{R}$ & 64.9 & $\mathrm{U}$ & $\mathrm{R}$ \\
13 & 8.9 & $\mathrm{R}$ & 0.55 & $\mathrm{R}$ & 18.0 & $\mathrm{R}$ & $\mathrm{S}$ \\
14 & 45.1 & $\mathrm{~S}$ & 1.88 & $\mathrm{R}$ & 68.5 & $\mathrm{U}$ & $\mathrm{U}$ \\
15 & 61.6 & $\mathrm{U}$ & 3.03 & $\mathrm{~S}$ & 94.9 & $\mathrm{U}$ & $\mathrm{R}$ \\
16 & 19.5 & $\mathrm{R}$ & 0.50 & $\mathrm{R}$ & 34.0 & $\mathrm{~S}$ & $\mathrm{R}$ \\
17 & 7.7 & $\mathrm{R}$ & 0.52 & $\mathrm{R}$ & 13.1 & $\mathrm{R}$ & $\mathrm{R}$ \\
18 & 16.8 & $\mathrm{R}$ & 0.30 & $\mathrm{R}$ & 29.7 & $\mathrm{~S}$ & $\mathrm{~S}$ \\
19 & 39.3 & $\mathrm{~S}$ & 3.56 & $\mathrm{~S}$ & 67.3 & $\mathrm{U}$ & $\mathrm{N}$ \\
\hline
\end{tabular}

Note. $\mathrm{R}=$ rural, $\mathrm{S}=$ suburban, $\mathrm{U}=$ urban. Impervious surface cover and total development cover were considered rural at $0-25 \%$, suburban at $25-50 \%$, and urban at $>50 \%$. Building density was considered rural at 0-2.5 bldgs/ha, suburban at 2.5-10 bldgs/ha, and urban at $>10$ bldgs/ha. Nests that fell into one urbanization category by at least 2 criteria were categorized as such. Nests that fell into all 3 categories over all 3 criteria were categorized as suburban.

\section{Diet Composition and Patterns}

The diet of nesting red-shouldered hawks in Santa Clara County consisted of a wide variety of prey species from five taxonomic classes (Appendix $B$ ). A minimum of 115 separate prey items were observed over $220.55 \mathrm{hr}$ of nest observation from 16 nests. Seventy-eight percent of all observed prey items 
were identified to class (90 of 115 prey items). Prey delivery over all 16 nests combined was 0.52 items per hour and $63.44 \mathrm{~g}$ per hour. Frequency and biomass of prey from each observed taxonomic class varied widely among nests (Table 5). Mammals comprised the largest portion of the diet overall, contributing $50.4 \%$ by frequency and $77.7 \%$ by biomass (Figure 4 ). Individual nests varied from a minimum of $14.3 \%$ to a maximum of $75.0 \%$ by frequency and a minimum of $3.0 \%$ to a maximum of $77.7 \%$ by biomass. Reptiles comprised the next largest portion of the overall diet, contributing $20.9 \%$ by frequency and $11.1 \%$ by biomass. Individual nests varied from a minimum of $0.0 \%$ to a maximum of $60.0 \%$ by frequency and minimum of $0.0 \%$ to a maximum of $85.0 \%$ by biomass. Birds, frogs, and crayfish were also observed in the diet to a much lesser extent. 


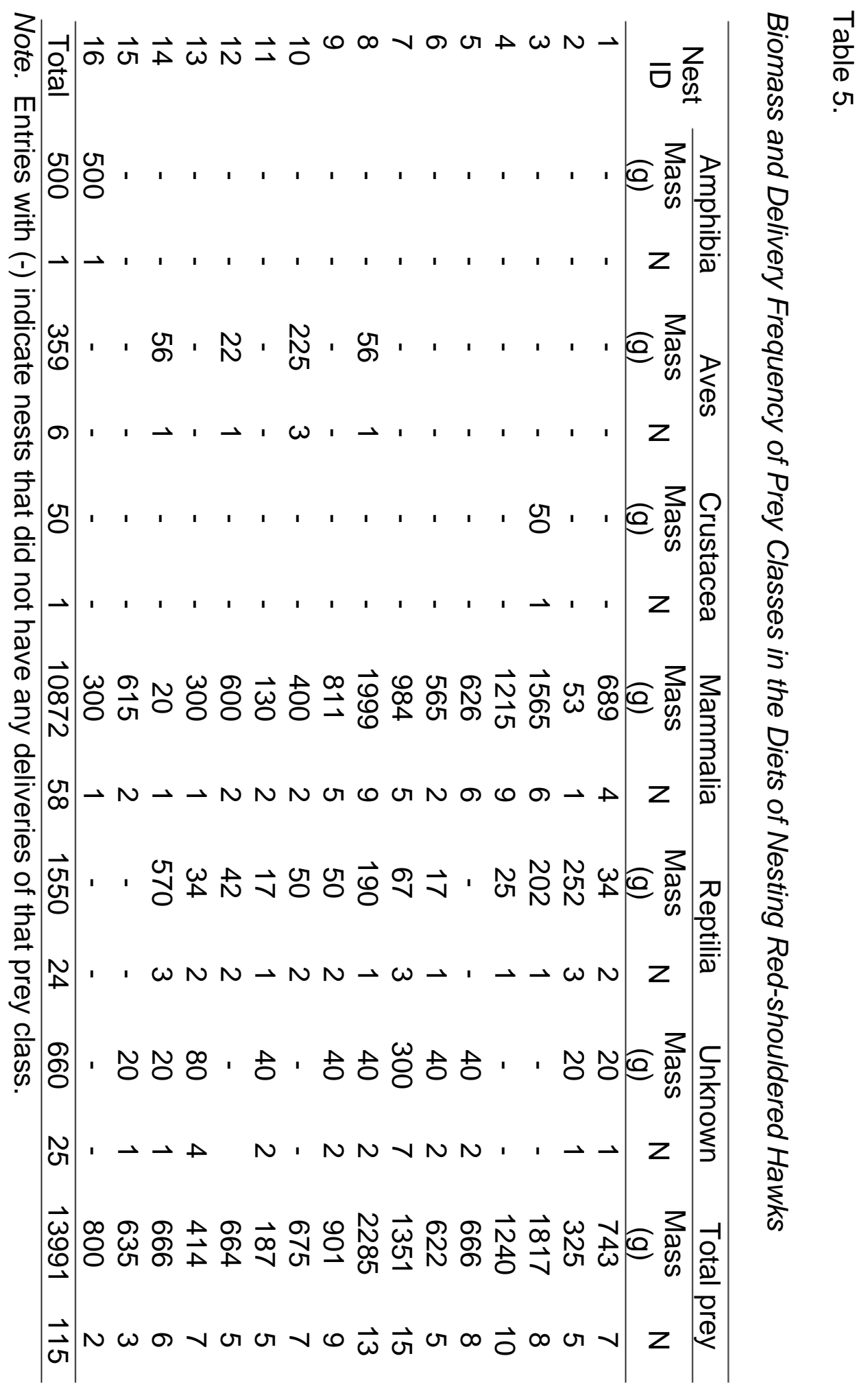




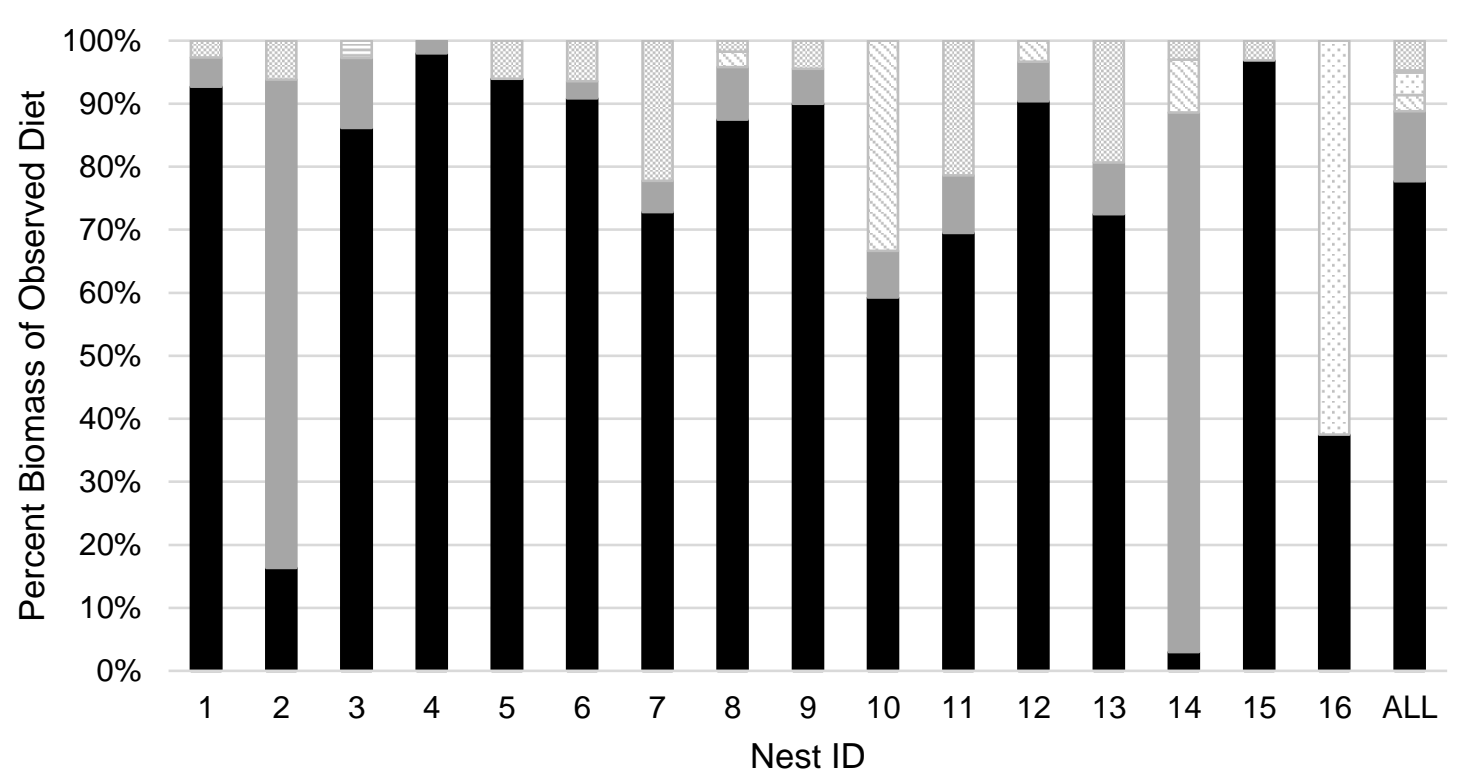
A
- Mammalia \% Mass
Reptilia \% Mass
Aves \% Mass
Amphibia \% Mass
自 Crustacea \% Mass
Unknown \% Mass

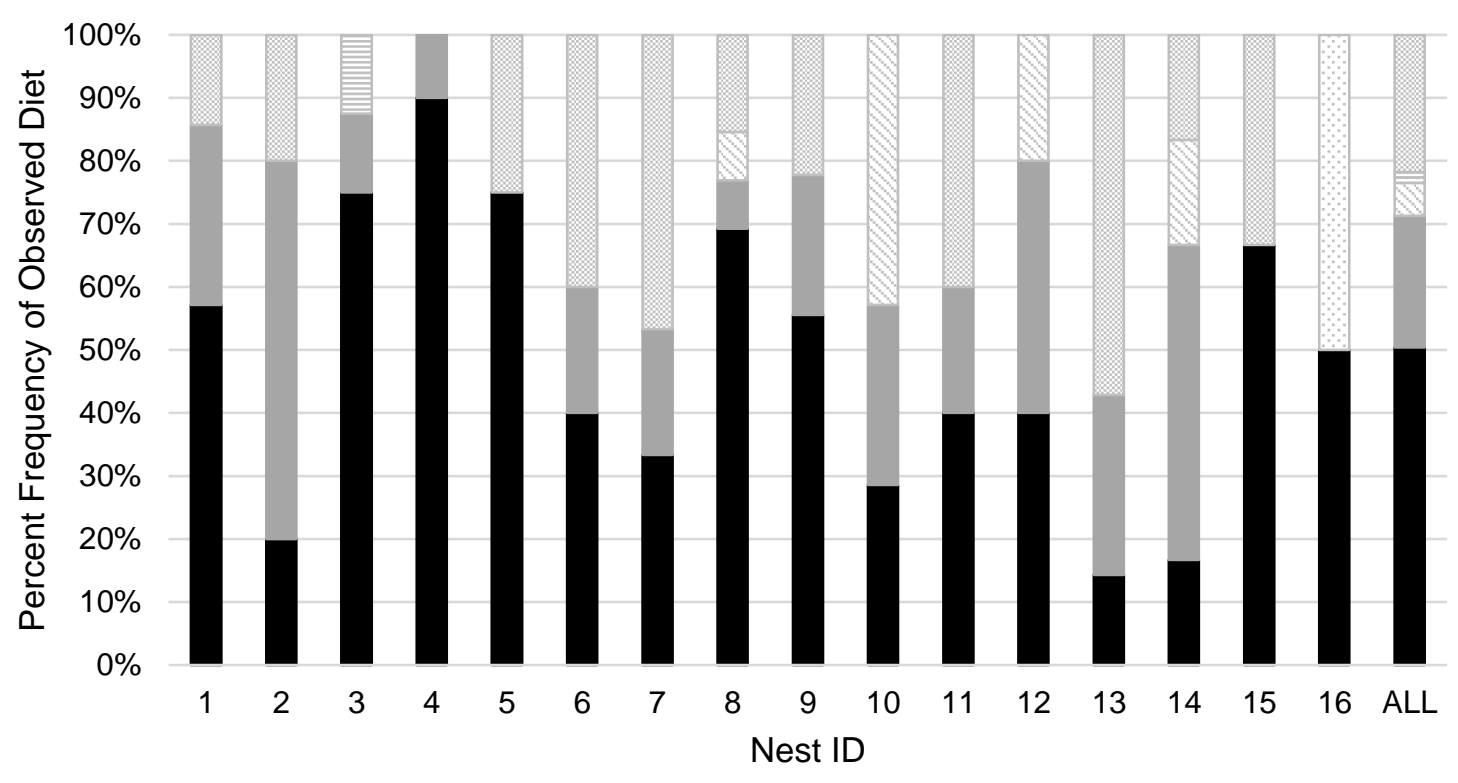

B

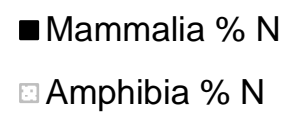

Reptilia \% N
- Crustacea \% N

Aves \% N

Unknown \% N

Figure 4. Percent biomass (A) and frequency (B) of prey classes in the diet of nesting red-shouldered hawks in Santa Clara County, CA. 
The PCA examining diet composition by prey delivery frequency showed no discernable patterns among urban, suburban, or rural nests (Figure 5).

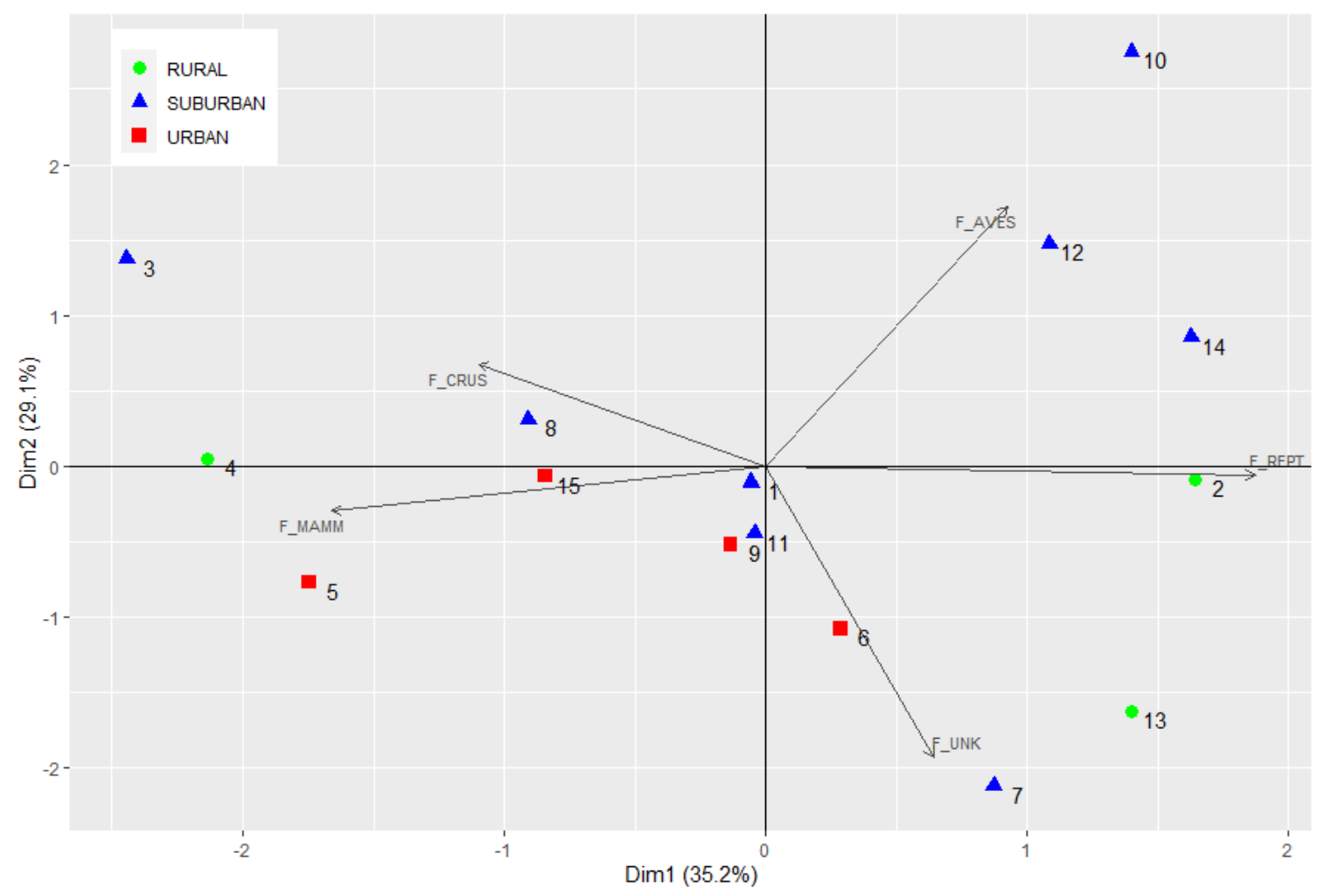

Figure 5. PCA of prey delivery frequency at 15 red-shouldered hawk nests (items/hr per nest). Point labels correspond with the nest ID. Loading arrows for each variable are shown, clockwise from top right: $F \_$AVES = biomass of avian prey, $F \_R E P T$ = biomass of reptile prey, $F \_U N K=$ biomass of unknown prey class, $\bar{F}$ _MAMM = biomass of mammal prey, F_CRUS = biomass of crustacean prey. Longer arrows indicate stronger loading along that dimension axis, and angles between arrows indicate correlation between variables.

In the PCA of diet composition by prey biomass, urban nests appeared to cluster together while suburban and rural nests showed no visible pattern (Figure 6). This clustering may be related to the fact that urban hawks relied almost entirely on rat and mouse biomass, and house mice (Mus musculus) and roof rats (Rattus rattus) were observed only at urban nests. 


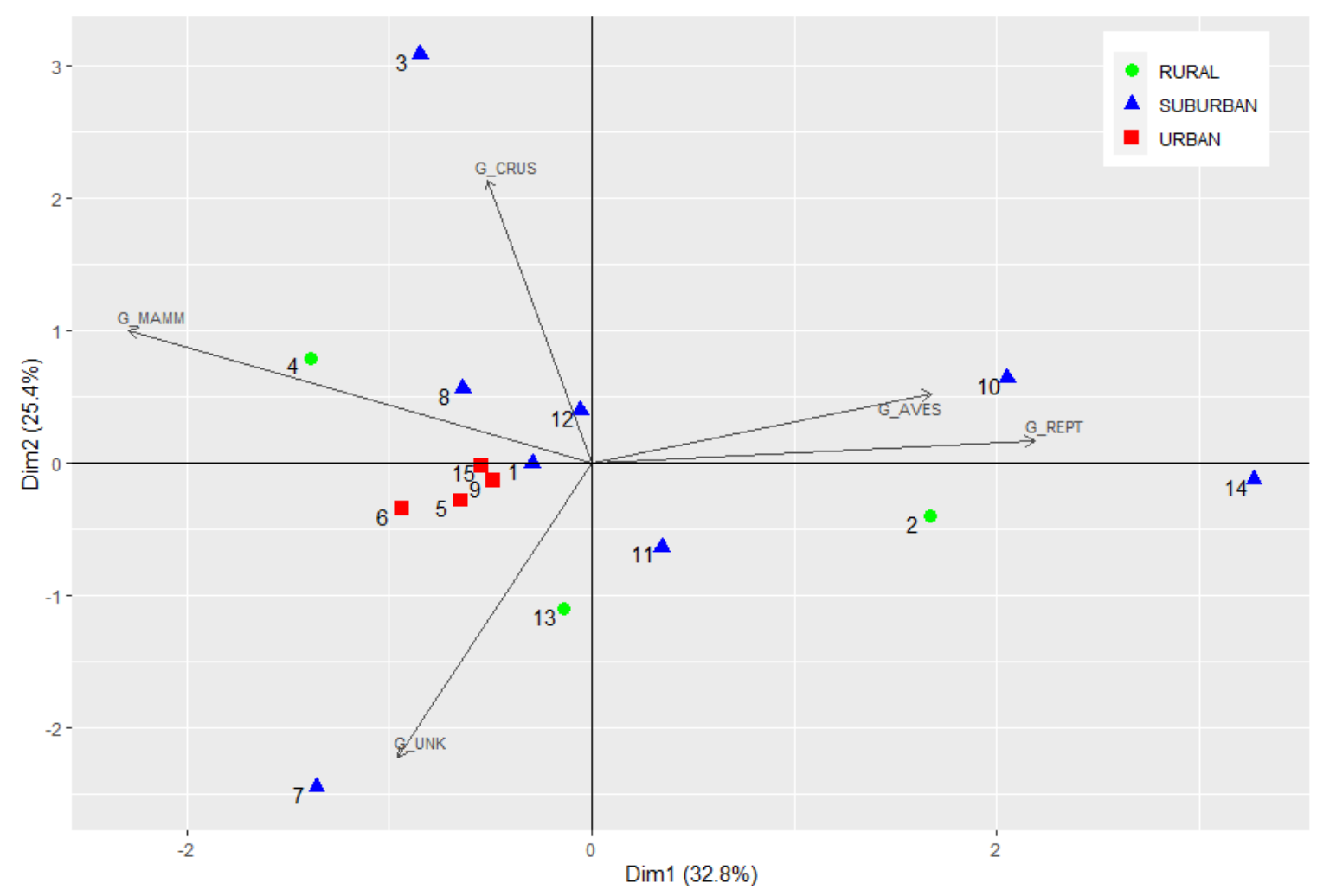

Figure 6. PCA of prey biomass delivered to 15 red-shouldered hawk nests $(\mathrm{g} / \mathrm{hr}$ per nest). Point labels correspond with the nest ID. Loading arrows for each variable are shown, clockwise from top: G_CRUS = biomass of crustacean prey, G_AVES = biomass of avian prey, G_REPT = biomass of reptile prey, G_UNK = biomass of unknown prey class, G_MAMM = biomass of mammal prey. arrows indicate stronger loading along that dimension axis, and angles between arrows indicate correlation between variables.

Suburban nests had the highest diversity of prey taxa overall, with 13 separate taxa observed, as well as the highest diversity of mammal taxa (eight). Suburban nests accounted for the only observed crayfish and all squirrels and birds. Rural nests had the highest diversity of reptile species (four), including single instances of California kingsnake (Lampropeltis getula) and ring-necked snake (Diadophis punctatus). The only observed amphibian prey, a bullfrog (Rana catesbeiana), was observed at a rural nest. 


\section{Human Activity}

A total of 5,858 individual external activities from both human and natural causes were observed at 16 nests over $187.23 \mathrm{hr}$ of nest observation (Table 6, Appendix C). Of all activities observed, $93.0 \%$ were caused by humans. Only one nest did not have any observed human activity. Pedestrians were the single largest source of activity, accounting for $50.8 \%$ of all observed activities. Average activity frequency at each nest ranged from a low of 8.8 activities per hour to a high of 63.5 activities per hour, averaging 31.3 activities per hour over all nests combined (Figure 7).

Table 6.

External Activities Observed at Red-shouldered Hawk Nests

\begin{tabular}{lcc}
\hline \multicolumn{1}{c}{ External activity type } & $\mathrm{N}$ & $\% \mathrm{~N}$ \\
\hline Human activity & 5446 & 92.97 \\
Aircraft & 115 & 1.96 \\
Cyclist & 1823 & 31.12 \\
Dog & 257 & 4.39 \\
Equipment & 21 & 0.36 \\
Noise & 189 & 3.23 \\
Pedestrian & 2978 & 50.84 \\
Vehicle & 63 & 1.08 \\
Natural activity & 412 & 7.03 \\
Crow alarm & 12 & 0.20 \\
Conspecific & 221 & 3.77 \\
Corvid & 27 & 0.46 \\
Squirrel & 2 & 0.03 \\
Other avian & 102 & 1.74 \\
Predator & 2 & 0.03 \\
Rain & 38 & 0.65
\end{tabular}




\begin{tabular}{ccc} 
Other raptor & 8 & 0.14 \\
\hline Total & 5858 & 100.00 \\
\hline Note. $\mathrm{N}=$ number of activities of a given type, $\% \mathrm{~N}=$ activities of a given type as \\
a percentage of all external activities observed.
\end{tabular}

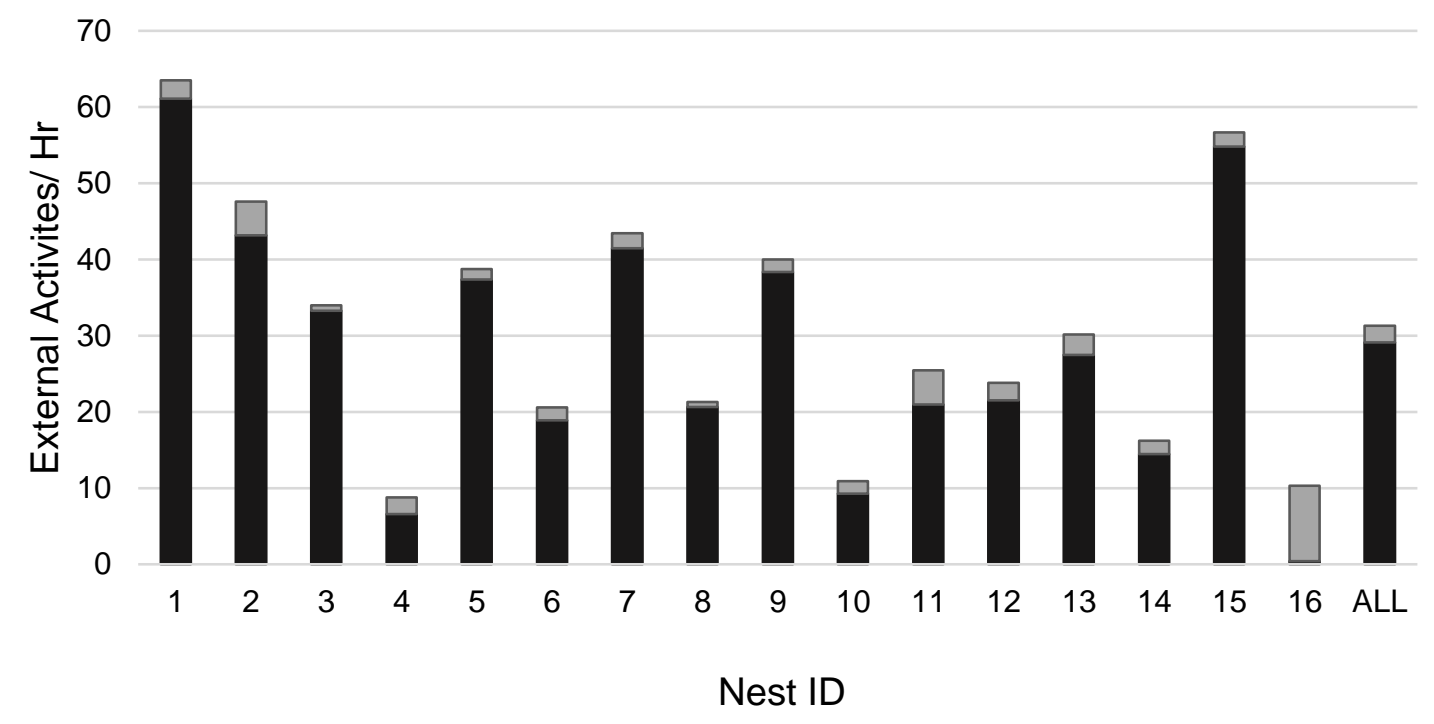

- Human Activity $\quad \square$ Natural Activity

Figure 7. Human and natural activities per hour at each nest, averaged over the total hours observed at each nest.

Parent and nestling Red-shouldered Hawks showed little overall reaction to external activities in the nest vicinity, with a mean of $3.5 \%$ of activities eliciting any visible behavioral response over all 16 nests (Table 7, Table 8 ). The response rate varied from a low of $0.6 \%$ to a high of $14.7 \%$. When birds did respond, $75.8 \%$ of those responses were alert, glance, look, and stare behaviors. 


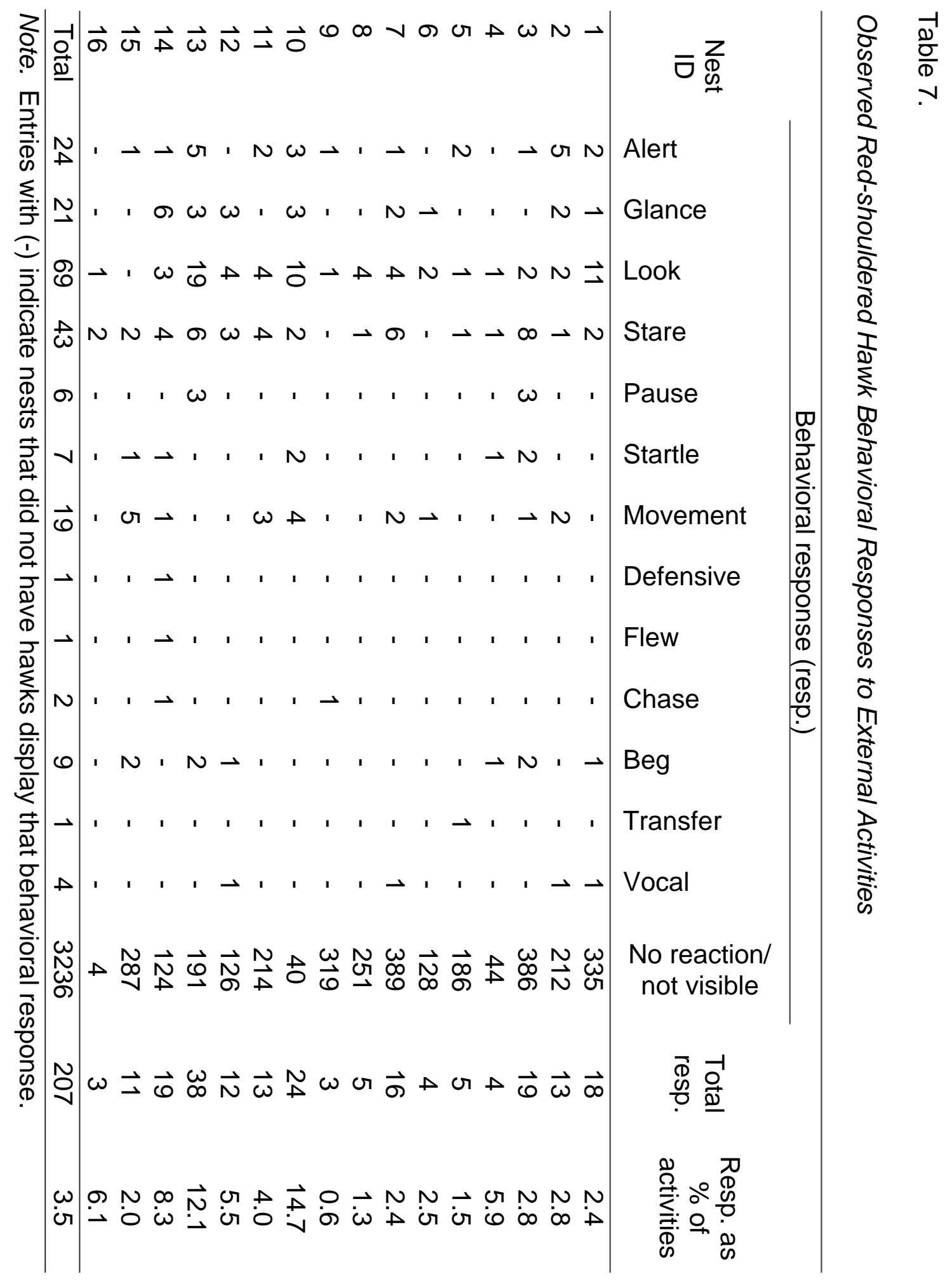


Table 8.

Definitions of Behavioral Responses Exhibited by Red-shouldered Hawks

\begin{tabular}{|c|c|}
\hline $\begin{array}{l}\text { Behavioral } \\
\text { Response }\end{array}$ & Definition \\
\hline Alert & On alert, looking around \\
\hline Glance & Quick look \\
\hline Look & Interested but calm watching \\
\hline Stare & Intent staring at cause of activity \\
\hline Pause & Brief pause in activity \\
\hline Startle & Hawk jumped/was visibly startled \\
\hline Movement & Varied - hawk made some kind of movement \\
\hline Defensive & Defensive posture, raised feathers \\
\hline Flew & Flew from nest \\
\hline Chase & Hawk pursued cause of activity \\
\hline Beg & Begging behavior by chicks (vocalizations, wing fluttering) \\
\hline Transfer & Activity directly preceded prey transfer to another hawk \\
\hline Vocal & Called/vocalized \\
\hline No reaction & No outward response \\
\hline Not visible & No hawk visible \\
\hline
\end{tabular}

\section{Habitat Selection and Urbanization}

Analysis of the 19 nests for 14 spatially derived habitat metrics identified a number of highly correlated variables (Table 9). Based on this analysis, five spatial variables were selected for use in subsequent habitat analyses:

1. All developed landcover (ALL_DEV, which correlated with distance to nearest building, total building number, shrub/grassland landcover, and impervious surface area),

2. Riparian area (RIP_AREA, which correlated with distance to water and creek length), 
3. Total road length (RD_LENGTH, which correlated with natural disturbance frequency),

4. Tree canopy cover (CANOPY, which correlated with forest and open space landcovers), and

5. Open space landcover (OPSP, which was considered important for inclusion as its own habitat predictor despite moderate correlation with CANOPY).

Agricultural and aquatic landcover were not included in the analyses, although not correlated with other variables, because occurrences of these landcovers were highly irregular within the zones of influence around nests. The selected five variables met assumptions of normality. 


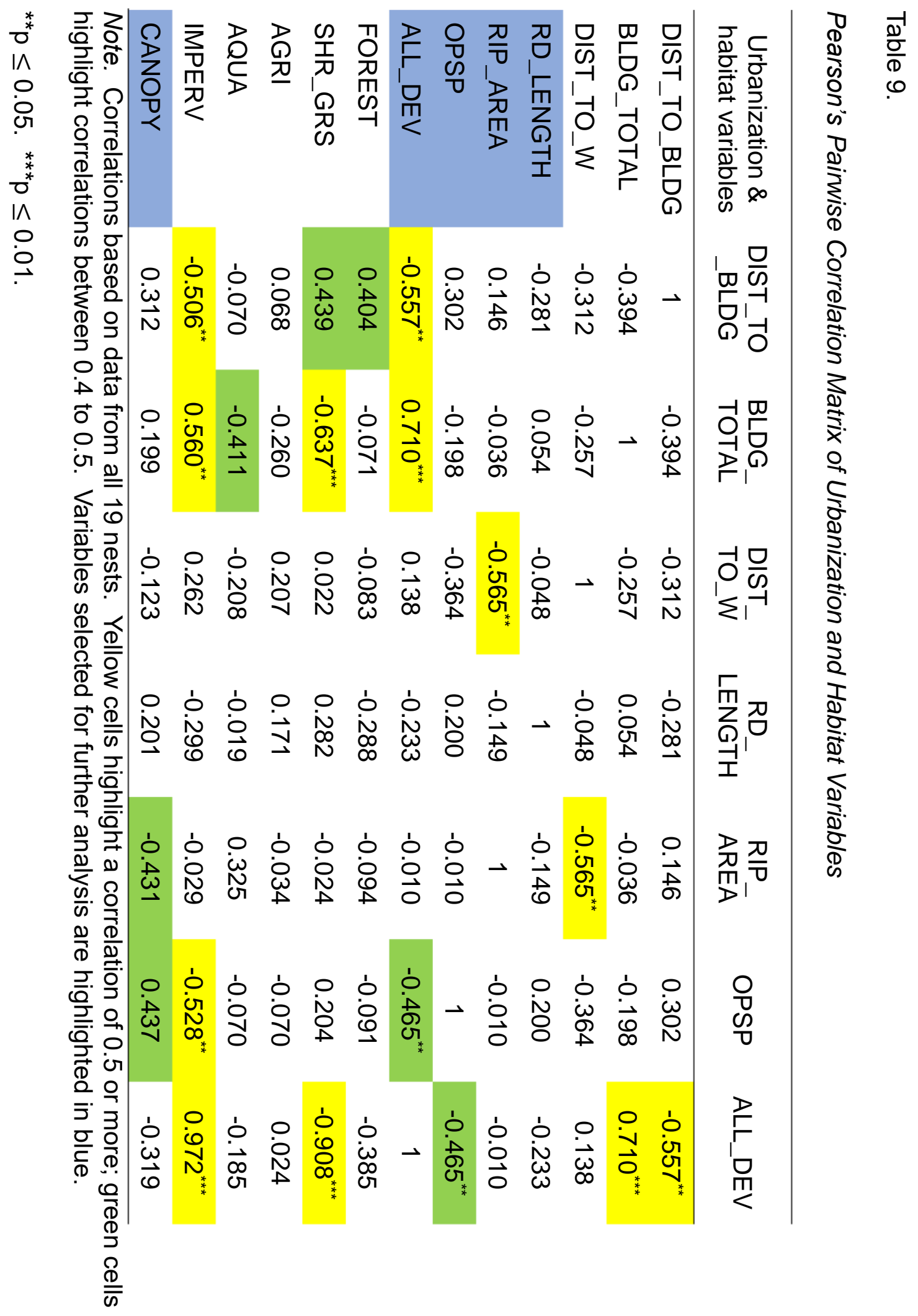




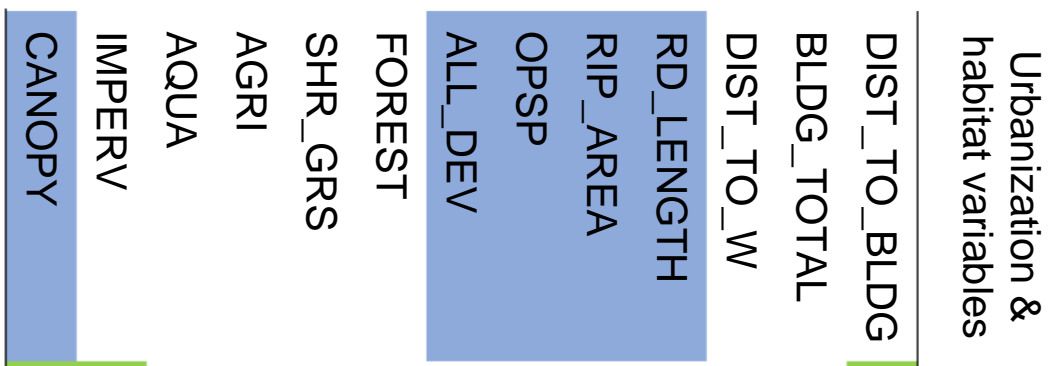

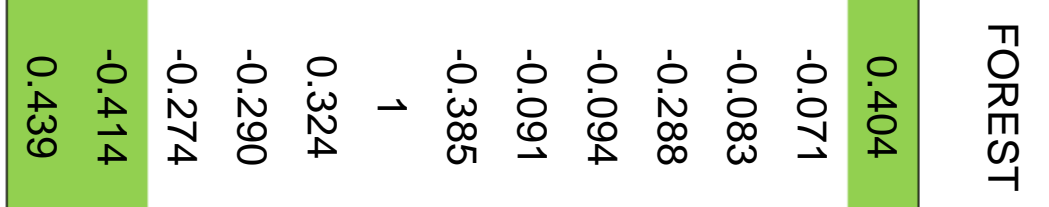

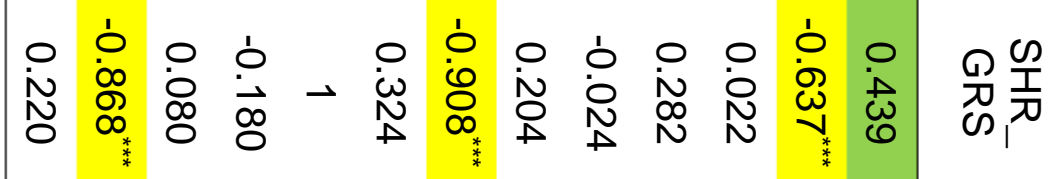

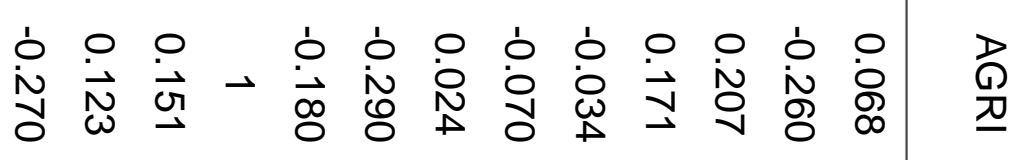

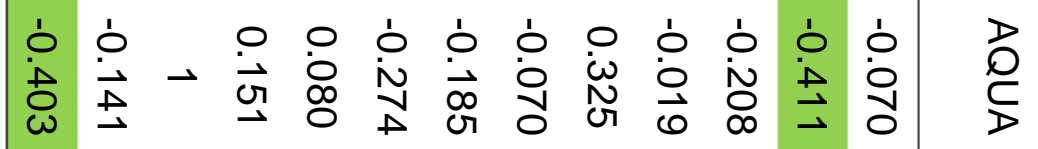

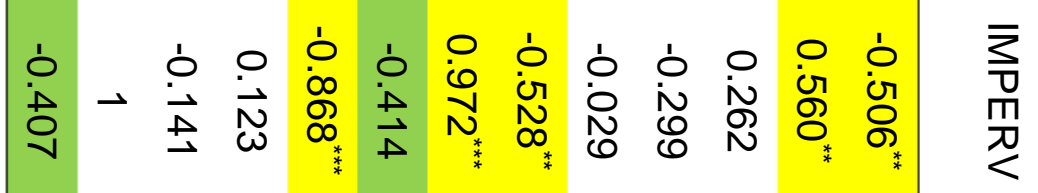

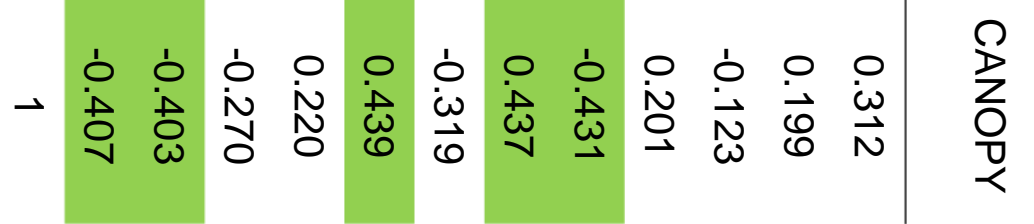


Red-shouldered hawks chose nest locations across a range of urbanization in Santa Clara County $(\mathrm{N}=19)$. In the PCA of habitat selection, nests showed groupings by urbanization categories (Figure 8). Urban nests were clustered at the highly developed end of the development axis, rural nests were clustered at the end of the open space and canopy axes, and suburban nests were in between. Thus, the classification system for these nests is supported.

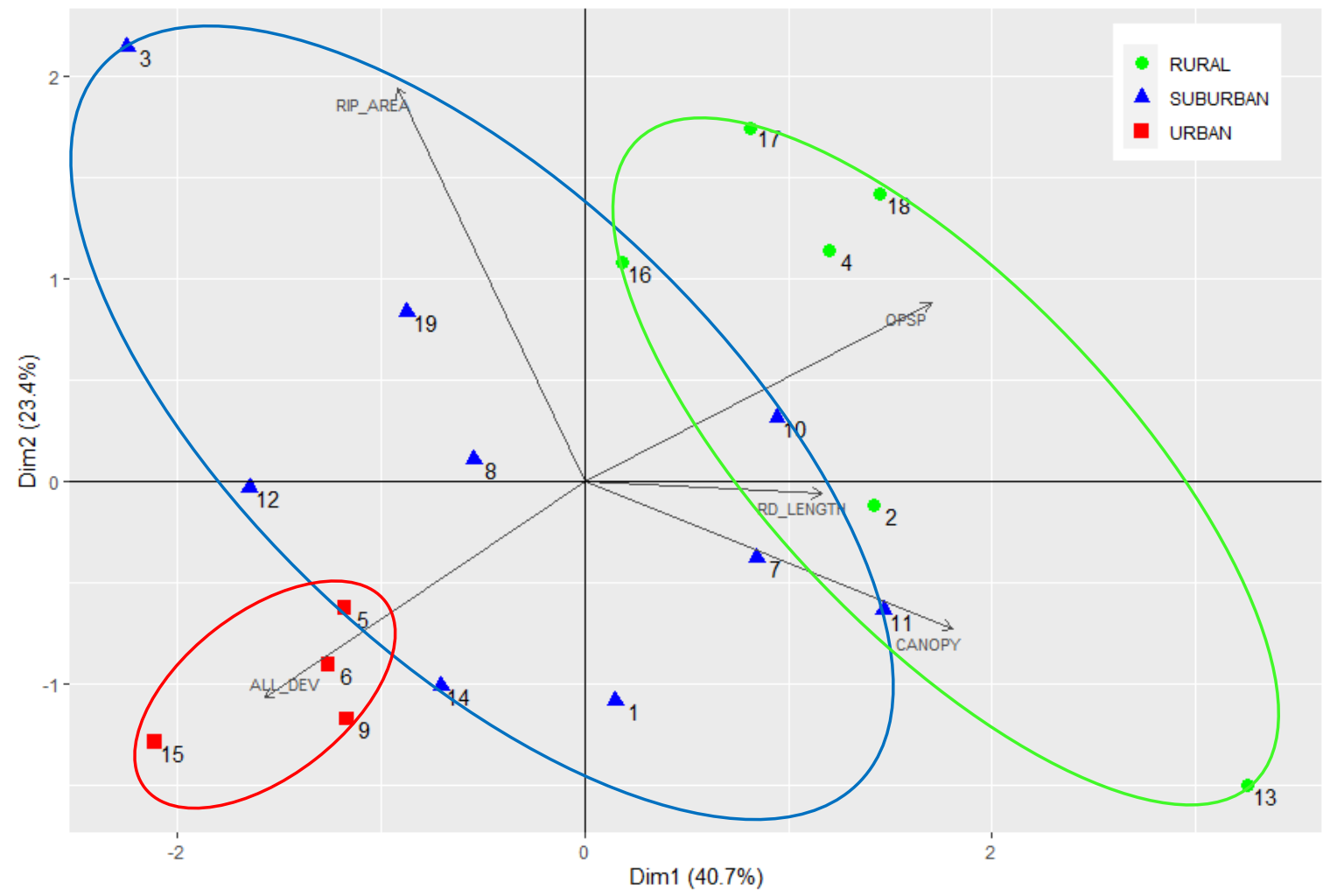

Figure 8. PCA of habitat and urbanization variables at 19 red-shouldered hawk nests in Santa Clara County, CA. Point labels correspond with the nest ID. Loading arrows for each variable are shown, clockwise from top left: RIP_AREA = riparian area, OPSP = open space landcover area, RD_LENGTH = total length of roads, CANOPY = total tree canopy cover area, ALL_DEV = total area of developed landcover. Longer arrows indicate stronger loading along that dimension axis, and angles between arrows indicate correlation between variables. Ellipses shown to illustrate the groupings. 
All five variables showed strong correlation with the first two dimensions (Table 10). The first three dimensions explained $81.34 \%$ of the variance among nests.

Table 10.

Results of Principal Component Analysis

\begin{tabular}{|c|c|c|c|c|c|}
\hline Variable & $\operatorname{Dim} 1$ & $\operatorname{Dim} 2$ & $\operatorname{Dim} 3$ & $\operatorname{Dim} 4$ & $\operatorname{Dim} 5$ \\
\hline & \multicolumn{5}{|c|}{ Variances } \\
\hline Eigenvalue & 2.037 & 1.168 & 0.862 & 0.543 & 0.390 \\
\hline Variance (\%) & 40.732 & 23.367 & 17.241 & 10.864 & 7.796 \\
\hline \multirow[t]{2}{*}{$\begin{array}{l}\text { Cumulative } \\
\text { Variance (\%) }\end{array}$} & 40.732 & 64.099 & 81.340 & 92.204 & 100.000 \\
\hline & \multicolumn{5}{|c|}{ Correlations } \\
\hline RD_LENGTH & 0.505 & -0.027 & 0.854 & 0.113 & 0.038 \\
\hline RIP_AREA & -0.399 & 0.840 & 0.050 & 0.184 & 0.313 \\
\hline OPSP & 0.737 & 0.380 & -0.229 & 0.400 & -0.314 \\
\hline ALL_DEV & -0.682 & -0.465 & 0.040 & 0.564 & 0.009 \\
\hline CANOPY & 0.784 & -0.317 & -0.275 & 0.134 & 0.438 \\
\hline
\end{tabular}

The number of chicks fledged showed no relationship with total prey biomass per nest per hour $\left(\mathrm{N}=15, \mathrm{r}_{\mathrm{s}}=0.297, \mathrm{p}=0.283\right)$, and showed a potential positive relationship with total prey frequency delivery per nest per hour $\left(N=15, r_{s}=\right.$ $0.491, p=0.063$ ). This result indicates that overall, adults brought enough food to feed three chicks even if they produced only one. 
There was no relationship between the number of chicks fledged $(\mathrm{N}=19)$ and any of the habitat variables: road length $\left(r_{s}=-0.028, p=0.910\right)$, developed landcover area $\left(r_{s}=-0.150, p=0.540\right)$, riparian area $\left(r_{s}=-0.390, p=0.099\right)$, open space landcover area $\left(r_{s}=0.017, p=0.946\right)$, or canopy cover area $\left(r_{s}=\right.$ $0.382, p=0.107)$. Nor was there a relationship between frequency of human activity and number of chicks fledged $\left(r_{s}=0.006, p=0.983, N=15\right)$.

The percent of nests that were successful by level of development were $100 \%$ for urban (4/4), $89 \%$ suburban (8/9) and $50 \%$ for rural $(3 / 6)$. Using all nests $(N=19$, Figure 9), no differences were seen among the number of chicks fledged at urban $(\bar{x} \pm S E=1.50 \pm 0.289, n=4)$, suburban $(\bar{x} \pm S E=1.67 \pm 0.289, n=$ 9), or rural nests $(\bar{x} \pm S E=1.33 \pm 0.615, n=6$; Kruskal-Wallis statistic $=0.267, p=$ $0.875, d f=2)$. Considering only successful nests $(N=15$, Figure 10$)$, numerically more chicks were fledged per rural nest $(\bar{x} \pm S E=2.67 \pm 0.333, n=3)$ than per urban $(\bar{x} \pm S E=1.50 \pm 0.289, n=4)$ or suburban nest $(\bar{x} \pm S E=1.90 \pm 0.227$; $n=8$ ) however too few nests were successful in each category to analyze the differences statistically. 


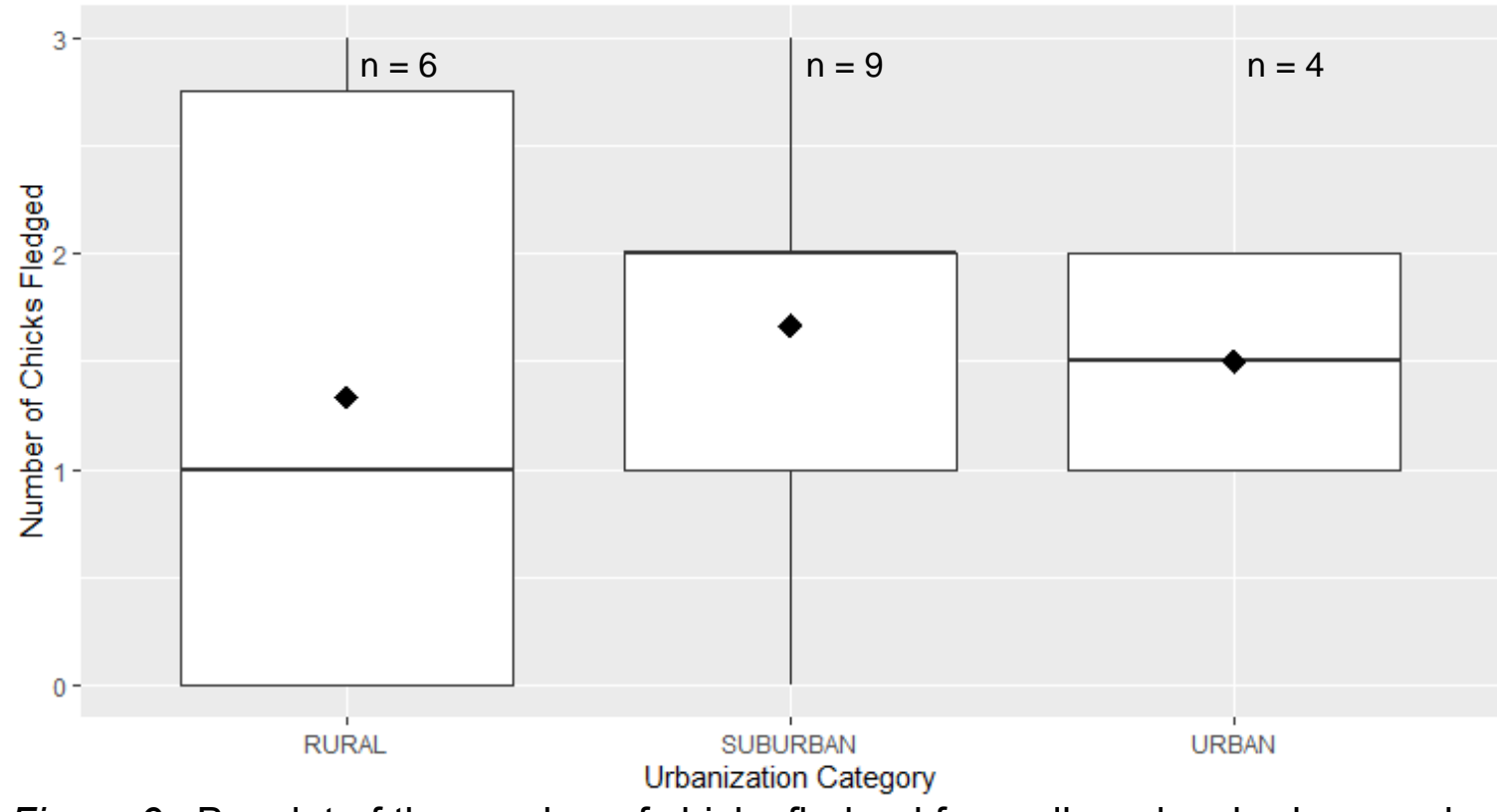

Figure 9. Boxplot of the number of chicks fledged from all rural, suburban, and urban nests $(N=19)$. Black diamond shape indicates the mean number of chicks fledged. Black horizontal line indicates the median number of chicks fledged.

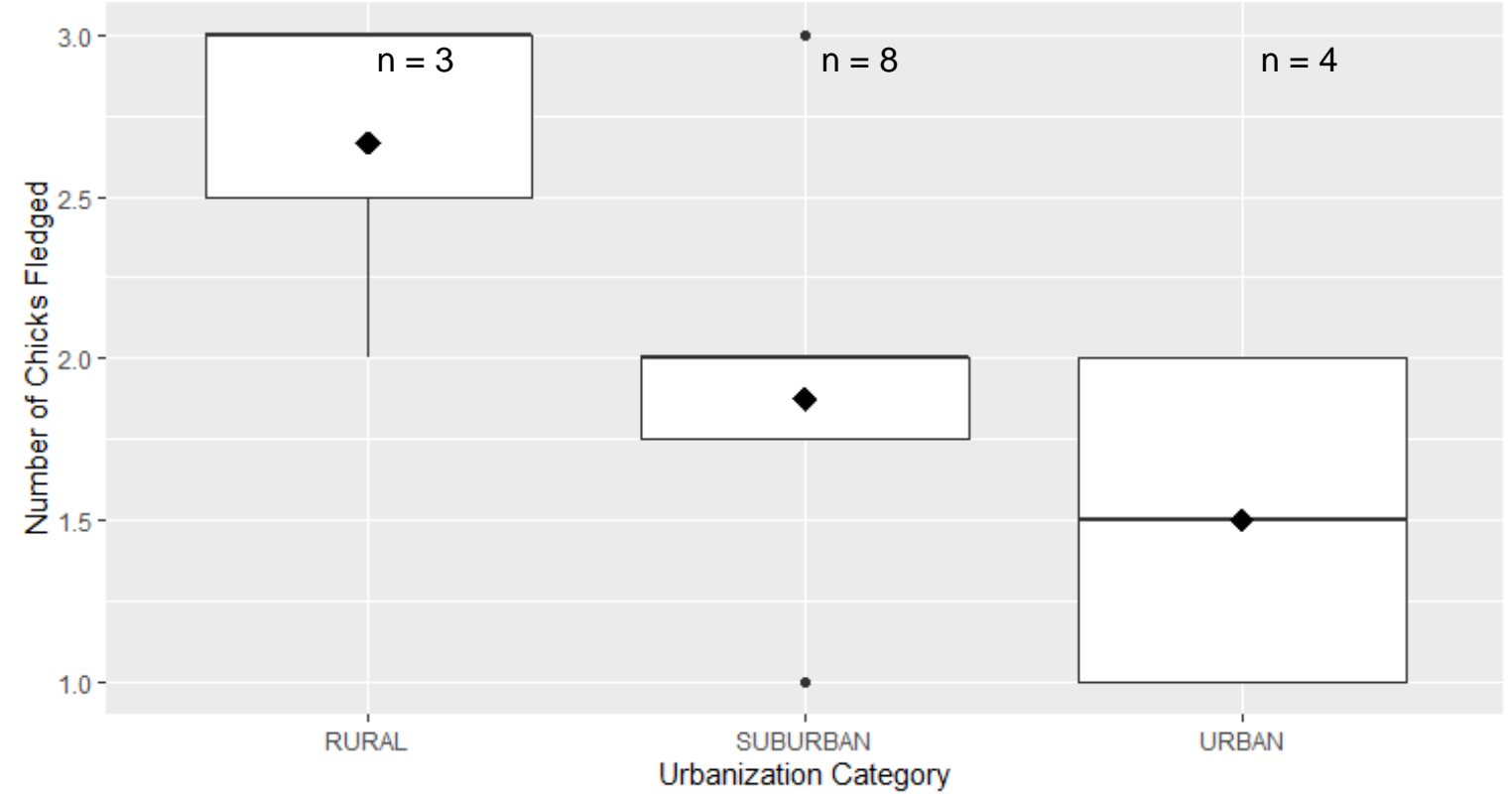

Figure 10. Boxplot of the number of chicks fledged from successful rural, suburban, and urban nests $(\mathrm{N}=15)$. Black diamond shape indicates the mean number of chicks. Black horizontal line indicates the median number of chicks fledged. 


\section{Variables Influencing Diet Composition}

Diet metrics with adequate data for analysis included total prey biomass, mammal biomass, reptile biomass, total prey frequency, mammal frequency, and reptile frequency. All were measured for each nest as per hour and per chick per hour.

Road length was significantly negatively correlated with five prey metrics, including mammal biomass and frequency per hour, total prey biomass per chick per hour, and mammal biomass and frequency per chick per hour. Road length was significantly positively correlated with reptile frequency per hour. Developed landcover was significantly positively correlated with total prey biomass per chick per hour and weakly positively correlated with mammal biomass and frequency per chick per hour. Canopy cover was significantly negatively correlated with total prey biomass per chick per hour. Human activity frequency was not correlated with any prey metrics (Table 11). 


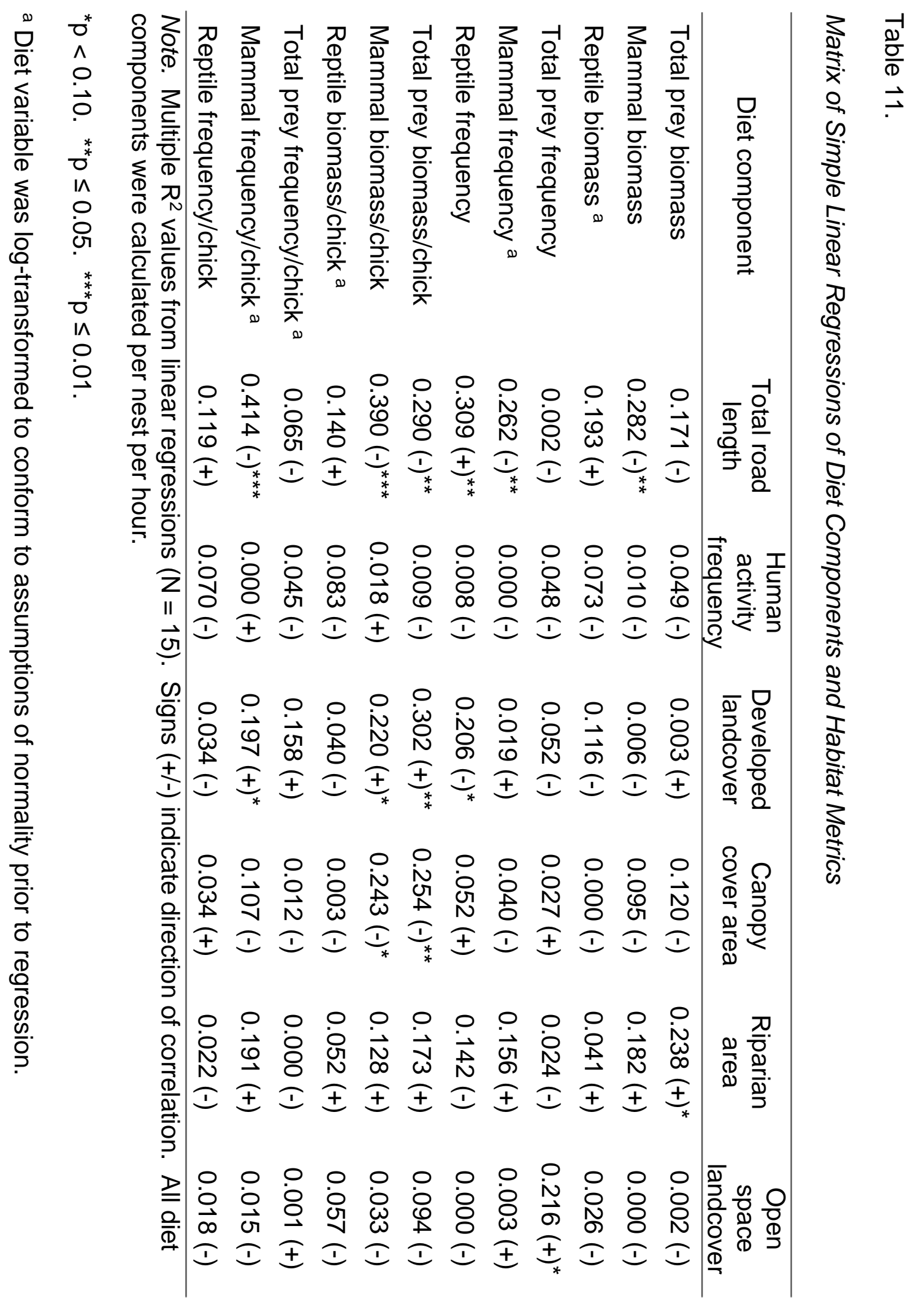




\section{Discussion}

This study was designed to assess the extent to which red-shouldered hawks are able to provide food and raise chicks in urban and suburban environments. This study found that red-shouldered hawks in Santa Clara County are able to find adequate prey to successfully nest in rural, suburban, and urban environments, but that prey type and amounts can vary across the urban gradient. Findings from this research are consistent with other studies that have also found red-shouldered hawks to be highly tolerant of urbanization (Bloom \& McCrary, 1996; Dykstra et al., 2018; Rottenborn, 2000).

The lack of clear patterns in prey composition among urban, suburban, and rural nests suggests that red-shouldered hawks are taking similar prey across the range of urbanization. The key prey items observed in Santa Clara County were mammals and reptiles. Rottenborn (1997) reported that hawks in Santa Clara County consumed primarily California vole (Microtus californicus) and Botta's pocket gopher (Thomomys bottae) based on pellet remains. Although I observed parent birds bringing both prey species in low proportions, rats (Rattus sp.) and California ground squirrels (Spermophilus beechyi) were far more prominent in the diet. However, many mammalian prey items were unidentified, and small mammals such as mice and voles may have been unidentified at a higher rate than larger, more easily identifiable prey.

An important finding was that increased developed landcover was associated with increased total prey biomass per chick per hour and mammal biomass and 
frequency per chick per hour, suggesting that larger or more abundant sources of mammal biomass is available in urban areas, such as roof rats. However, the biomass and number of mammals per nest and biomass of mammals per chick decreased as the length of road increased near nests, indicating that this aspect of urbanization may be detrimental to red-shouldered hawk mammal prey. Roadways and developed landcover provide very different habitats to prey species and should be considered separately for the purposes of determining prey habitat. Development, associated with not only roads but buildings, vegetated lots, and human debris, may provide more foraging and habitat opportunities for mammals than roadways.

Reptiles comprised a large percentage of the diet for some nests, and overall accounted for nearly $21 \%$ of prey items, consistent with diet observations in Ohio (Dykstra et al., 2003). Unlike mammals, increased road length was associated with increased reptile frequency per nest per hour, possibly due to the attraction of sun-warmed roadways to basking reptiles and increased visibility to predators on exposed pavement. Overall, however, the frequency of reptile delivery to nests declined with increasing developed landcover. Few invertebrates were observed compared to other studies (Dykstra et al., 2003; Snyder \& Wiley, 1976), but the small size of such prey items may have caused them to go undetected in this study.

The association between riparian area and increased total biomass supports research suggesting that riparian areas provide higher habitat quality for hawks 
(Bloom et al., 1993), but given the strong association of red-shouldered hawk presence with wetlands and riparian corridors in the literature (Balcerzak \& Wood, 2003; Bloom et al., 1993; Dykstra, Daniel, et al., 2001; Portnoy \& Dodge, 1979; Rottenborn, 2000), riparian habitats were expected to have a much stronger correlation with other diet components as well. The lack of significant correlations between diet and riparian area may be due to the highly developed nature of creek and river corridors in the Santa Clara Valley, where the habitat benefits (and thus prey abundance) may be much lower than in less disturbed regions. It is also possible that western populations of red-shouldered hawks are less reliant on riparian areas than eastern populations, and this simply reflects normal variation within the western population.

Although red-shouldered hawks are generally considered forest-dwelling raptors, in the Santa Clara Valley increased canopy was associated with less mammal and total prey biomass per chick per hour. Increased open space, despite my initial predictions of habitat value, was associated only with total prey frequency per nest per hour, suggesting more abundant but smaller prey items.

Red-shouldered hawks in Santa Clara County are subject to high levels of external activity, mostly from anthropogenic sources, but appear to have habituated to human activity. Energy-intensive behaviors such as chasing intruders or flushing from the nest were rarely observed, suggesting that redshouldered hawks are not expending unnecessary energy as a result of nearby human activity. Although this study was unable to assess the effects of vehicular 
traffic near nests, the lack of effect of human activity frequency on prey delivery rates, biomass, or chicks fledged suggest that red-shouldered hawks in Santa Clara County overall are tolerant of most human activity. Some hypotheses for this behavior include species tolerance promoting synurbic behavior, selection of urban habitat by only disturbance-tolerant hawks, or habituation (Bonier et al., 2007; Cavalli, Baladròn, Isacch, Biondi, \& Bò, 2018; Møller, 2010; Sol et al., 2013). Research designed to distinguish between these hypotheses would be necessary assess the reasons behind the observed behavioral tolerance.

Red-shouldered hawk nest locations spanned a range of urbanization in the Santa Clara Valley, from urban to rural. The categorization method employed in this study using building density, developed landcover, and impervious surface cover was supported by the clustering of nests within a PCA of landcover metrics. The PCA was self-referential to a limited extent, as one metric used in the categorization of nests (developed landcover) was also used as one of the metrics to construct the PCA itself. However, the categorization process incorporated the use of two additional metrics, and the PCA incorporated four additional habitat variables. The use of multiple continuous metrics in combination, rather than the use of descriptive labels or reliance on a single metric, may be useful in further studies. Comparisons between studies of urban ecology is challenging (Kettel et al., 2018; Marzluff et al., 2001), and the use of quantifiable metrics allow for more meaningful comparisons across highly diverse development patterns. 
Although there was no significant difference in the number of chicks fledged among urban, suburban, and rural nests, the rural nests had a higher mean number of chicks fledged per successful nest than suburban or urban nests. This suggests that the distribution of chicks within categories may not be equivalent: rural nests may fledge more chicks per successful nest but are more likely to fail compared to suburban or urban nests. Conversely, urban nests fledged fewer chicks per successful nest, but no urban nests failed. Dykstra, Hays, and Simon (2009) observed both spatial and temporal variation in nest productivity in Ohio, where rural nest productivity varies from year to year but less so from nest area to nest area, while suburban nest productivity varied more from nest area to nest area but remained consistent year to year. Rottenborn (2000) found similar mean values for nest productivity in Santa Clara County in 1994 (1.8 chicks per nest and 2.3 chicks per successful nest) and 1995 (1.6 chicks per nest and 2.0 chicks per successful nest). Bloom and McCrary (1996) found a mean of 1.80 young fledged per nesting attempt and 2.50 young fledged per successful nesting attempt. In a 19-yr study in Ohio reported by Dykstra et al. (2018), suburban hawks produced 1.55 young per active nest and 2.59 young per successful nest, while rural hawks produced 1.54 young per active nest and 2.61 young per successful nest.

Overall red-shouldered hawk nest success in this study was very similar to success rates calculated by Rottenborn (2000) for Santa Clara County redshouldered hawks in 1994 (77.8\%) and 1995 (79.3\%). In southern California, 
reported nest success rates range from $65.5 \%$ (Wiley, 1975) to $72 \%$ (Bloom \& McCrary, 1996). Santa Clara County red-shouldered hawks appeared to have slightly higher overall nest success but on average slightly fewer fledged young per nest compared to other regions reported in the literature, based on the available data.

The number of chicks fledged did not appear to be driven by any of the habitat metrics used, indicating that other variables were more significant factors affecting reproductive output. Consistent total prey biomass per nest suggests that prey availability was not a limiting factor in the number of chicks fledged. It is possible that increased prey delivery may increase chicks fledged, but results were inconclusive and require further study.

Red-shouldered hawks are remarkably adaptable in dietary preferences (Bednarz \& Dinsmore, 1985; Strobel \& Boal, 2010) and the observed diet is only truly representative for the study year. Additionally, the study design could not adequately capture temporal trends, whether in time of day, prey fluctuations over days or weeks, or yearly differences due to weather patterns, rainfall, or human activity. Long-term diet studies over several breeding seasons may show stronger trends in prey selection and reveal larger patterns associated with weather or other phenomena.

Given these caveats, the data collected in this study provides land managers with a starting point for making informed decisions for urban raptor conservation. Red-shouldered hawks are highly adaptable and tolerant of human activity, 
successfully nesting in highly disturbed areas adjacent to human development and recreation. Protection of open spaces that serve both conservation and recreational purposes will likely provide adequate prey and nesting habitat for red-shouldered hawks. Red-shouldered hawk presence also serves as a useful indicator of prey species availability, particularly of small mammalian and reptilian prey. 


\section{Recommendations for Management and Future Research}

The presence of disturbance-tolerant raptors such as red-shouldered hawks in urban landscapes provides land managers with unique opportunities for conservation and public education. For red-shouldered hawks, the dual needs of habitat conservation and non-consumptive human recreation are potentially compatible land uses. Although the protection of at least some natural open space is critical for providing appropriate habitat for red-shouldered hawk nesting and foraging, this species is tolerant of at least some human activity and will successfully breed within urbanized landscapes (Bloom \& McCrary, 1996;

Dykstra et al., 2018). Conservation is not limited to wild areas and understanding urban and suburban ecosystems is necessary for effective wildlife management within urbanized landscapes.

Nesting red-shouldered hawks may be considered bioindicators in an urbanized landscape. Successful nesting indicates that prey populations are currently adequate to support reproductive efforts in the locations studied. Providing habitat specifically for prey species may enhance the survival of larger predatory species and assist with retaining biodiversity and biological community structure even in highly urbanized areas. The efficacy of habitat conservation may be improved by limiting road construction in open space areas, as this type of landcover likely reduces habitat for prey species. Robust conservation programs also provide opportunities to educate the urban public about wildlife and the importance of biodiversity at the local level (McKinney, 2002). 
The population dynamics of urban raptor species are still largely unknown (DeStephano \& Boal, 2018). Long-term studies of red-shouldered hawk breeding success and productivity would provide a more complete, accurate picture of whether urban populations are stable over time. Studies on the dispersal of fledged chicks would provide information on juvenile survival in developed environments and indicate the extent to which urban and rural subpopulations interact. Furthermore, additional research is needed to discern other factors that affect urban reproductive success beyond food availability, such as predation pressure, nest tree availability, or pollution effects.

Urban food webs and prey availability are not well understood (Fischer et al., 2012). Long-term diet studies of urban raptors may capture yearly changes in prey availability, such as those caused by natural prey population fluctuations, weather events, or sustained drought. Studies that assess prey abundance in conjunction with prey captures could determine the extent to which redshouldered hawks adjust their prey selection to the availability of specific species.

Although studies have shown that many urban species are tolerant of human disturbance, authors offer a range of hypotheses to explain what causes such a change (Bonier et al., 2007; Francis \& Chadwick, 2012; Sol et al., 2013). Behavioral assessments that compare urban versus rural red-shouldered hawk responses could identify possible mechanisms of behavioral change in this species. 
Lastly, more focused studies on urban habitat use will provide more detailed guidelines for land managers with specific conservation goals in mind. Riparian areas are hotspots of biodiversity in Santa Clara County, but they are also sensitive to disturbance from anthropogenic activity in urban areas (Rottenborn, 1999). Red-shouldered hawks are typically associated with riparian corridors (Bloom et al., 1993; Dykstra et al., 2000; Rottenborn, 2000). It would be useful to study the true extent of their association with riparian habitat in California, particularly in comparisons between urban and rural landscapes and among different levels of anthropogenic disturbance. 


\section{Literature Cited}

Alberti, M., Botsford, E., \& Cohen, A. (2001). Quantifying the urban gradient: Linking urban planning and ecology. In J. M. Marzluff, R. Bowman, \& R. Donnelly (Eds.), Avian ecology and conservation in an urbanizing world (pp. 89-115). Boston, MA: Springer.

Balcerzak, M. J., \& Wood, P. B. (2003). Red-shouldered hawk (Buteo lineatus) abundance and habitat in a reclaimed mine landscape. The Journal of Raptor Research, 37, 188-197. Retrieved from https://sora.unm.edu/node/54041

Bednarz, J. C., \& Dinsmore, J. J. (1982). Nest-sites and habitat of redshouldered and red-tailed hawks in lowa. The Wilson Bulletin, 94, 31-45. Retrieved from https://www.jstor.org/stable/4161575

Bielefeldt, J., Rosenfield, R. N., \& Papp, J. M. (1992). Unfounded assumptions about diet of the Cooper's hawk. The Condor, 94, 427-436. https://doi.org/10.2307/1369215

Bird, D. M., Varland, D. E., \& Negro, J. J. (Eds.). (1996). Raptors in human landscapes: Adaptations to built and cultivated environments. San Diego, CA: Academic Press.

Blair, R. B. (1996). Land use and avian species diversity along an urban gradient. Ecological Applications, 6, 506-519. https://doi.org/10.2307/2269387

Blair, R. B. (2001). Creating a homogeneous avifauna. In J. M. Marzluff, R. Bowman, \& R. Donnelly (Eds.), Avian ecology and conservation in an urbanizing world (pp. 459-486). Boston, MA: Springer.

Bloom, P. H., \& McCrary, M. D. (1996). The urban buteo: Red-shouldered hawks in southern California. In D. M. Bird, D. E. Varland, \& J. J. Negro (Eds.), Raptors in human landscapes: Adaptations to built and cultivated environments (pp. 31-39). San Diego, CA: Academic Press.

Bloom, P. H., McCrary, M. D., \& Gibson, M. J. (1993). Red-shouldered hawk home-range and habitat use in southern California. The Journal of Wildlife Management, 57, 258-265. https://doi.org/10.2307/3809422

Bloom, P. H., Scott, J. M., Papp, J. M., Thomas, S. E., \& Kidd, J. W. (2011). Vagrant western red-shouldered hawks: Origins, natal dispersal patterns, and survival. The Condor, 113, 538-546. https://doi.org/10.1525/cond.2011.100052 
Boal, C. W. (2018). Urban raptor communities: Why some raptors and not others occupy urban environments. In C. W. Boal \& C. R. Dykstra (Eds.), Urban raptors: Ecology and conservation of birds of prey in cities (pp. 36-50). Washington, DC: Island Press.

Boal, C. W., \& Dykstra, C. R. (Eds.). (2018). Urban raptors: Ecology and conservation of birds of prey in cities. Washington, DC: Island Press.

Boal, C. W., \& Mannan, R. W. (1999). Comparative breeding ecology of Cooper's hawks in urban and exurban areas of southeastern Arizona. The Journal of Wildlife Management, 63, 77-84. https://doi.org/10.2307/3802488

Bolger, D. T. (2001). Urban birds: Population, community, and landscape approaches. In J. M. Marzluff, R. Bowman, \& R. Donnelly (Eds.), Avian ecology and conservation in an urbanizing world (pp. 155-177). Boston, MA: Springer.

Bonier, F., Martin, P. R., \& Wingfield, J. C. (2007). Urban birds have broader environmental tolerance. Biology Letters, 3, 670-673. https://doi.org/10.1098/rsbl.2007.0349

Bousman, W. G. (Ed.). (2007). Breeding bird atlas of Santa Clara County, California. Cupertino, CA: Santa Clara Valley Audubon Society.

Braun, C. E., Tomlinson, R. E., \& Wann, G. T. (2015). Seasonal dynamics of mourning dove (Zenaida macroura) body mass and primary molt. The Wilson Journal of Ornithology, 127, 630-638. https://doi.org/10.1676/14-158.1

Cade, T. J., Martell, M., Redig, P., Septon, G., \& Hordoff, H. (1996). Peregrine falcons in urban North America. In D. M. Bird, D. E. Varland, \& J. J. Negro (Eds.), Raptors in human landscapes: Adaptations to built and cultivated environments (pp. 3-13). San Diego, CA: Academic Press.

Cava, J. A., Stewart, A. C., \& Rosenfield, R. N. (2012). Introduced species dominate the diet of breeding urban Cooper's hawks in British Columbia. The Wilson Journal of Ornithology, 124, 775-782. https://doi.org/10.1676/15594491-124.4.775

Cavalli, M., Baladrón, A. V., Isacch, J. P., Biondi, L. M., \& Bó, M. S. (2018). The role of habituation in the adjustment to urban life: An experimental approach with burrowing owls. Behavioural Processes, 157, 250-255. https://doi.org/10.1016/j.beproc.2018.10.011 
Chace, J. F., \& Walsh, J. J. (2006). Urban effects on native avifauna: A review. Landscape and Urban Planning, 74, 46-69. https://doi.org/10.1016/j.landurbplan.2004.08.007

Chamberlain, D. E., Cannon, A. R., Toms, M. P., Leech, D. I., Hatchwell, B. J., \& Gaston, K. J. (2009). Avian productivity in urban landscapes: A review and meta-analysis. Ibis, 151, 1-18. https://doi.org/10.1111/j.1474919x.2008.00899.x

Cooke, R., Hogan, F., Isaac, B., Weaving, M., \& White, J. G. (2018). Powerful owls: Possum assassins move into town. In C. W. Boal \& C. R. Dykstra (Eds.), Urban raptors: Ecology and conservation of birds of prey in cities (pp. 152-165). Washington, DC: Island Press.

Craighead, J. J., \& Craighead, F. C. (1956). Hawks, owls, and wildlife. Harrisburg, PA: Stackpole.

DeStephano, S., \& Boal, C. W. (2018). Perspectives and future directions. In C. W. Boal \& C. R. Dykstra (Eds.), Urban raptors: Ecology and conservation of birds of prey in cities (pp. 273-286). Washington, DC: Island Press.

Dykstra, C. R. (2018). City lifestyles: Behavioral ecology of urban raptors. In C. W. Boal \& C. R. Dykstra (Eds.), Urban raptors: Ecology and conservation of birds of prey in cities (pp. 18-35). Washington, DC: Island Press.

Dykstra, C. R., Bloom, P. H., \& McCrary, M. D. (2018). Red-shouldered hawks: Adaptable denizens of the suburbs. In C. W. Boal \& C. R. Dykstra (Eds.), Urban raptors: Ecology and conservation of birds of prey in cities (pp. 110125). Washington, DC: Island Press.

Dykstra, C. R., Daniel, F. B., Hays, J. L., \& Simon, M. M. (2001). Correlation of red-shouldered hawk abundance and macrohabitat characteristics in southern Ohio. The Condor, 103, 652-656. https://doi.org/10.1093/condor/103.3.652

Dykstra, C. R., Hays, J. L., \& Crocoll, S. T. (2008). Red-shouldered hawk (Buteo lineatus) (version 2.0). In A. F. Poole (Ed.), The Birds of North America. Ithaca, NY: Cornell Lab of Ornithology. https://doi.org/10.2173/bna.107.

Dykstra, C. R., Hays, J. L., Daniel, F. B., \& Simon, M. M. (2000). Nest site selection and productivity of suburban red-shouldered hawks in southern Ohio. The Condor, 102, 401-408. https://doi.org/10.1093/condor/102.2.401 
Dykstra, C. R., Hays, J. L., Daniel, F. B., \& Simon, M. M. (2001). Home range and habitat use of suburban red-shouldered hawks in southwestern Ohio.

The Wilson Bulletin, 113, 308-316. https://doi.org/10.1676/00435643(2001)113[0308:HRAHUO]2.0.CO;2

Dykstra, C. R., Hays, J. L., \& Simon, M. M. (2009). Spatial and temporal variation in reproductive rates of the red-shouldered hawk in suburban and rural Ohio. The Condor, 111, 177-182.

https://doi.org/10.1525/cond.2009.080002

Dykstra, C. R., Hays, J. L., Simon, M. M., \& Daniel, F. B. (2003). Behavior and prey of nesting red-shouldered hawks in southwestern Ohio. The Journal of Raptor Research, 37, 177-187. Retrieved from https://sora.unm.edu/node/54040

Estes, W. A., \& Mannan, R. W. (2003). Feeding behavior of cooper's hawks at urban and rural nests in southeastern Arizona. The Condor, 105, 107-116. https://doi.org/10.1093/condor/105.1.107

Evans, K. L., Chamberlain, D. E., Hatchwell, B. J., Gregory, R. D., \& Gaston, K. J. (2011). What makes an urban bird? Global Change Biology, 17, 32-44. https://doi.org/10.1111/j.1365-2486.2010.02247.x

Fischer, J. D., Cleeton, S. H., Lyons, T. P., \& Miller, J. R. (2012). Urbanization and the predation paradox: The role of trophic dynamics in structuring vertebrate communities. BioScience, 62, 809-818. https://doi.org/10.1525/bio.2012.62.9.6

Francis, R. A., \& Chadwick, M. A. (2012). What makes a species synurbic? Applied Geography, 32, 514-521. https://doi.org/10.1016/j.apgeog.2011.06.013

Gil, D., \& Brumm, H. (Eds.). (2014). Avian urban ecology: Behavioural and physiological adaptations. Oxford: Oxford University Press.

Griffith, G.E., Omernik, J.M., Smith, D.W., Cook, T.D., Tallyn, E., Moseley, K., \& Johnson, C.B. (2016). Ecoregions of California (U.S. Geological Survey Open-File Report 2016-1021, with map, scale 1:1,100,000) [Poster]. https://doi.org/10.3133/ofr20161021

Guiry, E. \& Buckley, M. (2018). Urban rats have less variable, higher protein diets. Proceedings of the Royal Society B Biological Sciences, 285(1889), 20181441. https://doi.org/10.1098/rspb.2018.1441 
Holland, V. L., \& Keil, D. J. (1995). California vegetation. Dubuque, IA: Kendall/Hunt Publishing.

Howell, D. L., \& Chapman, B. R. (1998). Prey brought to red-shouldered hawk nests in the Georgia piedmont. The Journal of Raptor Research, 32, 257260. Retrieved from https://sora.unm.edu/node/53696

Hull, J. M., Strobel, B. N., Boal, C. W., Hull, A. C., Dykstra, C. R., Irish, A. M., . . Ernest, H. B. (2008). Comparative phylogeography and population genetics within Buteo lineatus reveals evidence of distinct evolutionary lineages. Molecular Phylogenetics and Evolution, 49, 988-996. https://doi.org/10.1016/j.ympev.2008.09.010

Jameson, E. W., Jr., \& Peeters, H. J. (2004). Mammals of California (2nd ed.). Berkeley, CA: University of California Press.

Jokimäki, J., Suhonen, J., Jokimäki-Kaisanlahti, M.-L., \& Carbó-Ramírez, P. (2016). Effects of urbanization on breeding birds in European towns: Impacts of species traits. Urban Ecosystems, 19, 1565-1577. https://doi.org/10.1007/s11252-014-0423-7

Kettel, E. F., Gentle, L. K., Quinn, J. L., \& Yarnell, R. W. (2018). The breeding performance of raptors in urban landscapes: A review and meta-analysis. Journal of Ornithology, 159, 1-18. https://doi.org/10.1007/s10336-017-1497-9

Kingsbury, B. A. (1995). Field metabolic rates of eurythermic lizard. Herpetologica, 51, 155-159. Retrieved from https://www.jstor.org/stable/3892583

Luniak, M. (2004). Synurbanization: Adaptation of animal wildlife to urban development. In W. W. Shaw, L. K. Harris, \& L. VanDruff (Eds.), Proceedings of the 4th International Symposium on Urban Wildlife Conservation (pp. 5055). Retrieved from https://cals.arizona.edu/pubs/adjunct/snr0704/

Mannan, R. W., \& Steidl, R. J. (2018). Demography of raptor populations in urban environments. In C. W. Boal \& C. R. Dykstra (Eds.), Urban raptors: Ecology and conservation of birds of prey in cities (pp. 51-63). Washington, DC: Island Press.

Marzluff, J. M. (2001). Worldwide urbanization and its effects on birds. In J. M. Marzluff, R. Bowman, \& R. Donnelly (Eds.), Avian ecology and conservation in an urbanizing world (pp. 19-47). Boston, MA: Springer. 
Marzluff, J. M. (2017). A decadal review of urban ornithology and a prospectus for the future. Ibis, 159, 1-13. https://doi.org/10.1111/ibi.12430

Marzluff, J. M., Bowman, R., \& Donnelly, R. (2001). A historical perspective on urban bird research: Trends, terms, and approaches. In J. M. Marzluff, R. Bowman, \& R. Donnelly (Eds.), Avian ecology and conservation in an urbanizing world (pp. 1-17). Boston, MA: Springer.

McDonnell, M. J., \& Pickett, S. T. A. (1990). Ecosystem structure and function along urban-rural gradients: An unexplored opportunity for ecology. Ecology, 71, 1232-1237. https://doi.org/10.2307/1938259

McKinney, M. L. (2002). Urbanization, biodiversity, and conservation: The impacts of urbanization on native species are poorly studied, but educating a highly urbanized human population about these impacts can greatly improve species conservation in all ecosystems. BioScience, 52, 883-890. https://doi.org/10.1641/0006-3568(2002)052[0883:UBAC]2.0.CO;2

McKinney, M. L. (2006). Urbanization as a major cause of biotic homogenization. Biological Conservation, 127, 247-260. https://doi.org/10.1016/j.biocon.2005.09.005

Mills, G. S., Dunning, J. B., Jr., \& Bates, J. M. (1989). Effects of urbanization on breeding bird community structure in southwestern desert habitats. The Condor, 91, 416-428. https://doi.org/10.2307/1368320

Mills, G. S., Dunning, J. B., Jr., \& Bates, J. M. (1991). The relationship between breeding bird density and vegetation volume. The Wilson Bulletin, 103, 468479. Retrieved from http://www.jstor.com/stable/4163050

Møller, A. P. (2010). Interspecific variation in fear responses predicts urbanization in birds. Behavioral Ecology, 21, 365-371. https://doi.org/10.1093/beheco/arp199

Morrison, J. L., Gottlieb, I. G. W., \& Pias, K. E. (2016). Spatial distribution and the value of green spaces for urban red-tailed hawks. Urban Ecosystems, 19, 1373-1388. https://doi.org/10.1007/s11252-016-0554-0

Multi-Resolution Land Characteristics Consortium. (2019a). NLCD 2016 land cover (CONUS) [GIS data file]. Retrieved from https://www.mrlc.gov/data

Multi-Resolution Land Characteristics Consortium. (2019b). NLCD 2016 percent developed imperviousness (CONUS) [GIS data file]. Retrieved from https://www.mrlc.gov/data 
Multi-Resolution Land Characteristics Consortium. (2019c). NLCD 2016 USFS tree canopy cover (CONUS) [GIS data file]. Retrieved from https://www.mrlc.gov/data

Multi-Resolution Land Characteristics Consortium. (n.d.). National land cover database 2016 (NLCD2016) legend [GIS data legend]. Retrieved from https://www.mrlc.gov/data/legends/national-land-cover-database-2016nlcd2016-legend

Nagy, R., Fusaro, A., Conard, W., \& Morningstar, C. (2019). Procambarus clarkii (Girard, 1852) [Fact sheet]. Retrieved October 14, 2019, from U.S. Geological Survey Nonindigenous Aquatic Species Database website: https://nas.er.usgs.gov/queries/FactSheet.aspx?speciesID=217

Newton, I. (1979). Population ecology of raptors. Vermillion, SD: Buteo Books.

Niemelä, J. (1999). Is there a need for a theory of urban ecology? Urban Ecosystems, 3, 57-65. https://doi.org/10.1023/A:1009595932440

Olouch, A. O. (1990). Breeding biology of the Louisiana red swamp crayfish Procambarus clarkia Girard in lake Naivasha, Kenya. Hydrobiologia, 208, 8592. https://doi.org/10.1007/bf00008447

Pagel, J. E., Anderson, C. M., Bell, D. A., Deal, E., Kiff, L., McMorris, F. A., . . . Sallinger, R. (2018). Peregrine falcons: The neighbors upstairs. In C. W. Boal \& C. R. Dykstra (Eds.), Urban raptors: Ecology and conservation of birds of prey in cities (pp. 180-195). Washington, DC: Island Press.

Portnoy, J. W., \& Dodge, W. E. (1979). Red-shouldered hawk nesting ecology and behavior. The Wilson Bulletin, 91, 104-117. Retrieved from https://www.jstor.org/stable/4161171

Rosenfield, R. N., Mannan, R. W., \& Milsap, B. A. (2018). Cooper's hawks: The bold backyard hunters. In C. W. Boal \& C. R. Dykstra (Eds.), Urban raptors: Ecology and conservation of birds of prey in cities (pp. 93-109). Washington, DC: Island Press.

Rottenborn, S. C. (1997). The impacts of urbanization on riparian bird communities in central California (Doctoral dissertation). Retrieved from ProQuest Dissertations Publishing. (Order No. 9810196)

Rottenborn, S. C. (1999). Predicting the impacts of urbanization on riparian bird communities. Biological Conservation, 88, 289-299.

https://doi.org/10.1016/S0006-3207(98)00128-1 
Rottenborn, S. C. (2000). Nest-site selection and reproductive success of urban red-shouldered hawks in central California. The Journal of Raptor Research, 34, 18-25. Retrieved from https://sora.unm.edu/node/53791

Rottenborn, S. C. (2007). Red-shouldered hawk. In W. G. Bousman (Ed.), Breeding bird atlas of Santa Clara County, California (pp. 180-181). Cupertino, CA: Santa Clara Valley Audubon Society.

Rullman, S., \& Marzluff, J. M. (2014). Raptor presence along an urban-wildland gradient: Influences of prey abundance and land cover. The Journal of Raptor Research, 48, 257-272. https://doi.org/10.3356/JRR-13-32.1

Rutz, C., Whittingham, M., J., \& Newton, I. (2006). Age-dependent diet choice in an avian top predator. Proceedings of the Royal Society B Biological Sciences, 273(1586), 579-586. https://doi.org/10.1098/rspb.2005.3353

Santa Clara County. (2018). Streetedge [GIS data file]. Retrieved on March 20, 2019 from https://data.sccgov.org/Transportation/Streetedge/bw3w-7xad

Santa Clara County. (2019a). County boundary (polygon) [GIS data file]. Retrieved on April 26, 2019 from http://gisdata2sccplanning.opendata.arcgis.com/datasets/county-boundary-polygon

Santa Clara County. (2019b). Santa Clara County ortho imagery 2018 [GIS data file]. Retrieved on September 28, 2019 from http://www.arcgis.com/home/item.html?id=88dea119cffe4cb189a046528dc0ef 09

Santa Clara Valley Water District. (2019a). Santa Clara County creeks [GIS data file]. Retrieved on October 14, 2019 from http://datavalleywater.opendata.arcgis.com/datasets/e74548aaba0e46918523d62645e2 83fd_9

Santa Clara Valley Water District. (2019b). Santa Clara County water bodies [GIS data file]. Retrieved on October 14, 2019 from http://datavalleywater.opendata.arcgis.com/datasets/d7b446de1e7d4c06a7fa50e6cec7 9fad_7

Seress, G., \& Liker, A. (2015). Habitat urbanization and its effects on birds. Acta Zoologica Academiae Scientiarum Hungaricae, 61(4), 373-408. https://doi.org/10.17109/azh.61.4.373.2015 
Shochat, E., Warren, P. S., Faeth, S. H., McIntyre, N. E., \& Hope, D. (2006). From patterns to emerging processes in mechanistic urban ecology. Trends in Ecology \& Evolution, 21, 186-191. https://doi.org/10.1016/j.tree.2005.11.019

Snyder, N. F. R., \& Wiley, J. W. (1976). Sexual size dimorphism in hawks and owls of North America. Battle Creek, Ml: American Ornithologists' Union.

Sol, D., Lapiedra, O., \& Gonzalez-Lagos, C. (2013). Behavioural adjustments for a life in the city. Animal Behaviour, 85, 1101-1112. https://doi.org/10.1016/j.anbehav.2013.01.023

Stebbins, R. C., \& McGinnis, S. M. (2012). Field guide to amphibians and reptiles of California (2nd ed.). Berkeley, CA: University of California Press.

Steenhof, K. (1983). Prey weights for computing percent biomass in raptor diets. The Journal of Raptor Research, 17, 15-27. Retrieved from https://sora.unm.edu/node/52859

Stout, W. E., \& Rosenfield, R. N. (2010). Colonization, growth, and density of a pioneer Cooper's hawk population in a large metropolitan environment. The Journal of Raptor Research, 44, 255-267. https://doi.org/10.3356/JRR-0926.1

Strobel, B. N., \& Boal, C. W. (2010). Regional variation in diets of breeding redshouldered hawks. The Wilson Journal of Ornithology, 122, 68-74. https://doi.org/10.1676/09-071.1

Trulio, L. A., \& Higgins, P. (2012). The diet of western burrowing owls in an urban landscape. Western North American Naturalist, 72, 348-356. https://doi.org/10.3398/064.072.0309

U.S. Census Bureau. (2010). Quickfacts: Santa Clara County, CA - land area in square miles, 2010 [Table entry]. Retrieved from https://www.census.gov/quickfacts/santaclaracountycalifornia

U.S. Census Bureau. (2017). Quickfacts: Santa Clara County, CA - population estimates, July 1, 2017 (V2017) [Table entry]. Retrieved from https://www.census.gov/quickfacts/santaclaracountycalifornia

U.S. Census Bureau. (2018). 2018 TIGER/Line Shapefiles [GIS data file]. Retrieved on January 31, 2019 from https://www.census.gov/geographies/mapping-files/time-series/geo/tiger-linefile.2018.html 
Vitousek, P. M., Mooney, H. A., Lubchenco, J., \& Melillo, J. M. (1997). Human domination of earth's ecosystems. Science, 277(5325), 494-499. https://doi.org/10.1126/science.277.5325.494

Weber, T., Blank, P., \& Sloan, A. (2008). Field validation of a conservation network on the eastern shore of Maryland, USA, using breeding birds as bioindicators. Environmental Management, 41, 538-550. https://doi.org/10.1007/s00267-008-9076-8

Welch, R. J. (1987). Food habits of the red-shouldered hawk in Wisconsin. The Passenger Pigeon, 49, 81-92. Retrieved from http://digicoll.library.wisc.edu/cgi-bin/EcoNatRes/EcoNatResid $x$ ?type $=$ article\&did=EcoNatRes.pp49n02.RWelch\&id=EcoNatRes.pp49n02\& isize $=\mathrm{M}$

White, J., H., Smith, J. M., Bassett, S. D., Brown, J. L., \& Ormsby, Z. E. (2018). Raptor nesting locations along an urban density gradient in the great basin, USA. Urban Ecosystems, 21, 51-60. https://doi.org/10.1007/s11252-0170705-y 


\section{Appendices}

\section{Appendix A: Nest Key}

Nest key describing each of the 19 red-shouldered hawk nests found during the 2019 breeding season in Santa Clara County, CA. Each entry includes the nest ID, nest code (used for field data collection), urbanization category, nest location, UTM coordinates, number of chicks fledged, a brief description of the nest site, a photo of the nest, and a GIS sample depicting the land covers within each nest buffer. Legend for all maps shown at right. All maps made by the author, April 10, 2020, using ArcMap 10.6.1 for Desktop. Land covers are from the 2016 National Land Cover Database produced by the Multi-Resolution Land Characteristics Consortium (MRLC, 2019a). Orthoimagery is from Santa Clara County (2018).

\begin{tabular}{|c|c|}
\hline 0 & Nest Location \\
\hline & Nest Buffer \\
\hline \multicolumn{2}{|c|}{ Land Cover } \\
\hline & Open Water \\
\hline & Developed, Open Space \\
\hline & Developed, Low Intensity \\
\hline & Developed, Medium Intensity \\
\hline & Developed, High Intensity \\
\hline & Barren Land \\
\hline & Evergreen Forest \\
\hline & Mixed Forest \\
\hline & Shrub/Scrub \\
\hline & Grassland/Herbaceous \\
\hline & Pasture/Hay \\
\hline & Cultivated Crops \\
\hline & Woody Wetlands \\
\hline & Emergent Herbaceous Wetlands \\
\hline
\end{tabular}

Nest ID: 1

Nest Code: ALQU

Urbanization: SUBURBAN
Location: Almaden Quicksilver County Park, McAbee Rd. Entrance - Whispering Pines Dr., San José UTM: 10S 5993214119261

\# chicks fledged: 2

Upland nest in a California fan palm (Washingtonia filifera) in the front yard of a singlefamily residence. The yard faced private open space land directly adjacent to Almaden Quicksilver County Park.
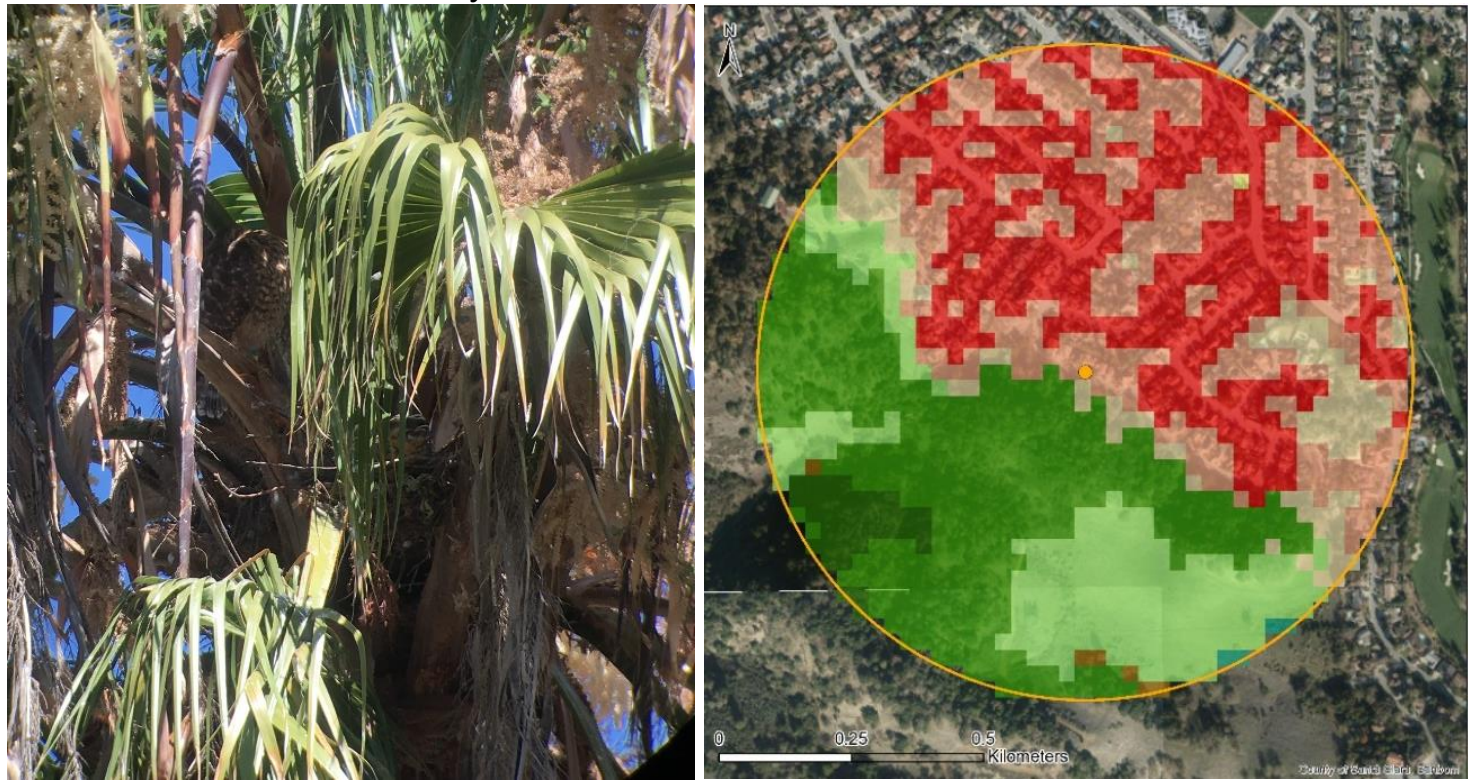
Nest ID: 2

Nest Code: ARAS

Urbanization: RURAL
Location: Pearson-Arastradero Preserve - Arastradero Rd., Palo Alto

UTM: 10S 5730244138100

\# chicks fledged: 2

Upland nest in a Eucalyptus sp. immediately across Arastradero Rd. from the gravel parking lot to the preserve.
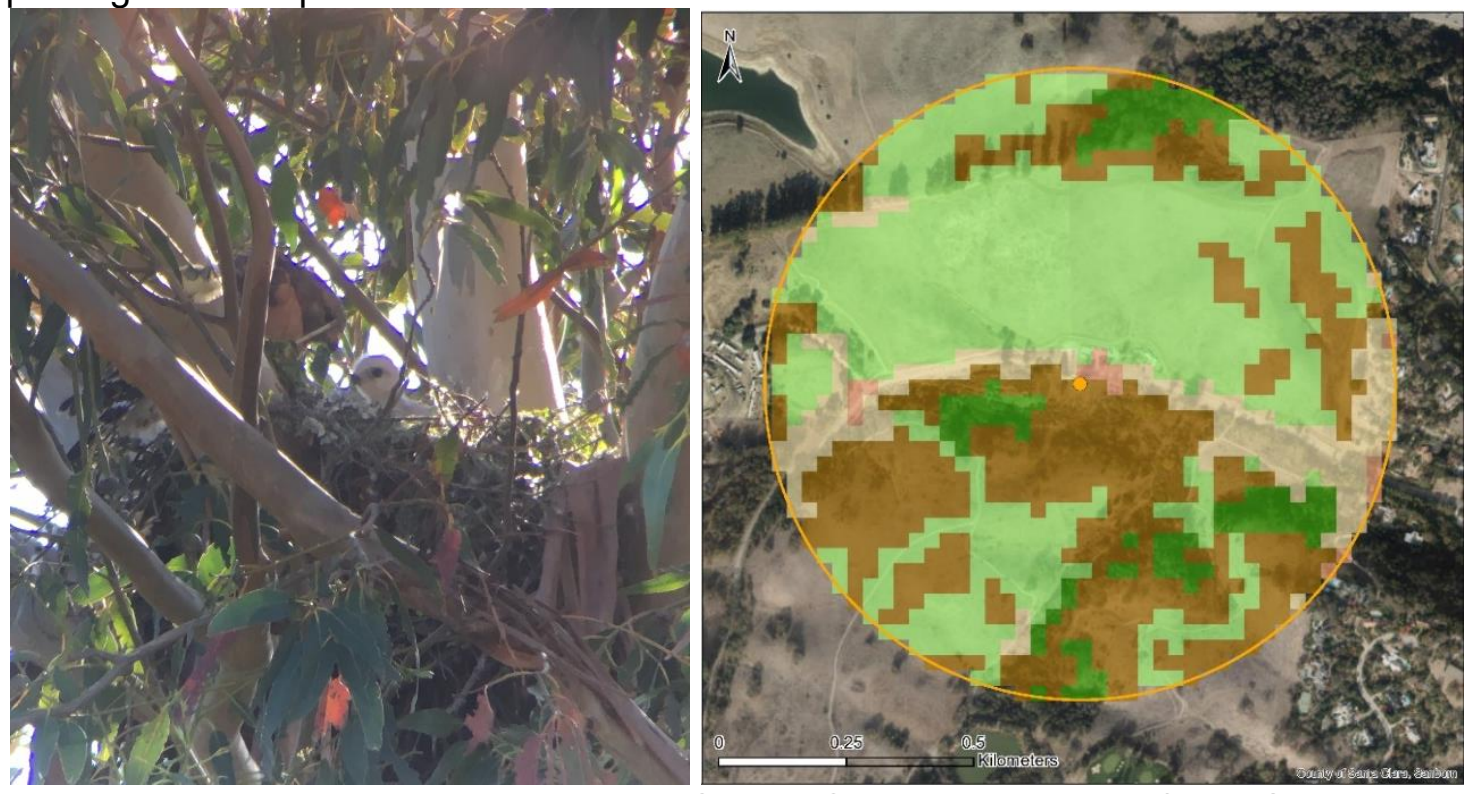

Nest ID: 3

Nest Code: CCME2

Urbanization: SUBURBAN \# chicks fledged: 2

Riparian nest in a Canary Island pine (Pinus canariensis) along the fence line near the northwest corner of the PG\&E Metcalf Transmission Substation. This was the second nest for this pair; the original nest was located on the opposite bank of Coyote Creek and failed early in the season. Only nest observed with crayfish prey.
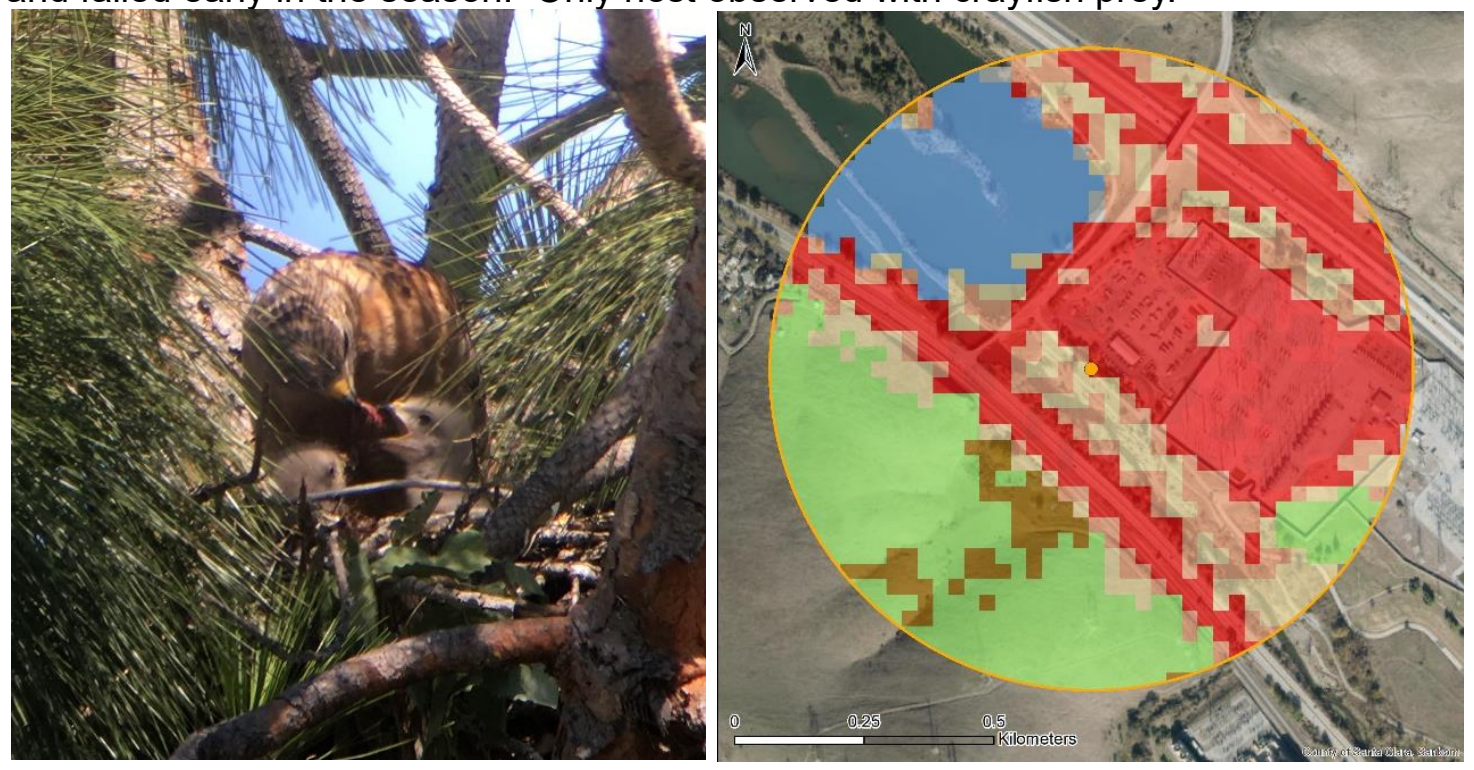
Nest ID: 4

Nest Code: EDLE Urbanization: RURAL
Location: Ed R. Levin County Park, Oak Knoll Group Area - Calaveras Rd. and Downing Rd., Milpitas UTM: 10 S 6010874144935 \# chicks fledged: 3

Riparian nest in a Eucalyptus sp. at the west end of the picnic area, just south of the road. Highly sensitive pair despite high usage of picnic area on weekends.
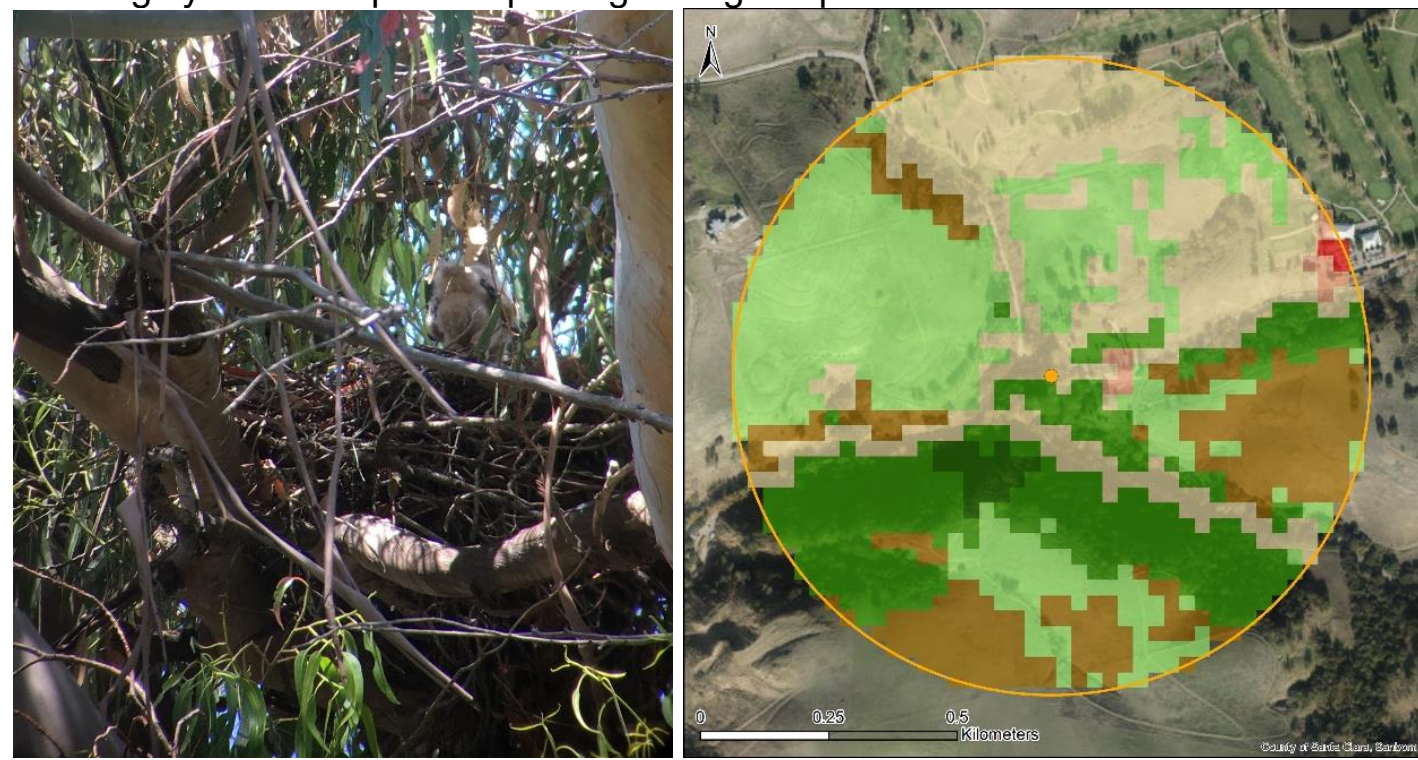

Nest ID: 5

Nest Code: GOOG Urbanization: URBAN

Location: Google Campus - Charleston Rd. and Shorebird Way, Mountain View UTM: 10S 5822374141901 \# chicks fledged: 1

Upland nest in a coast redwood (Sequoia sempervirens) next to a Google office building. Difficult to access during the week due to office traffic and activity. Only pair with a subadult parent (female).
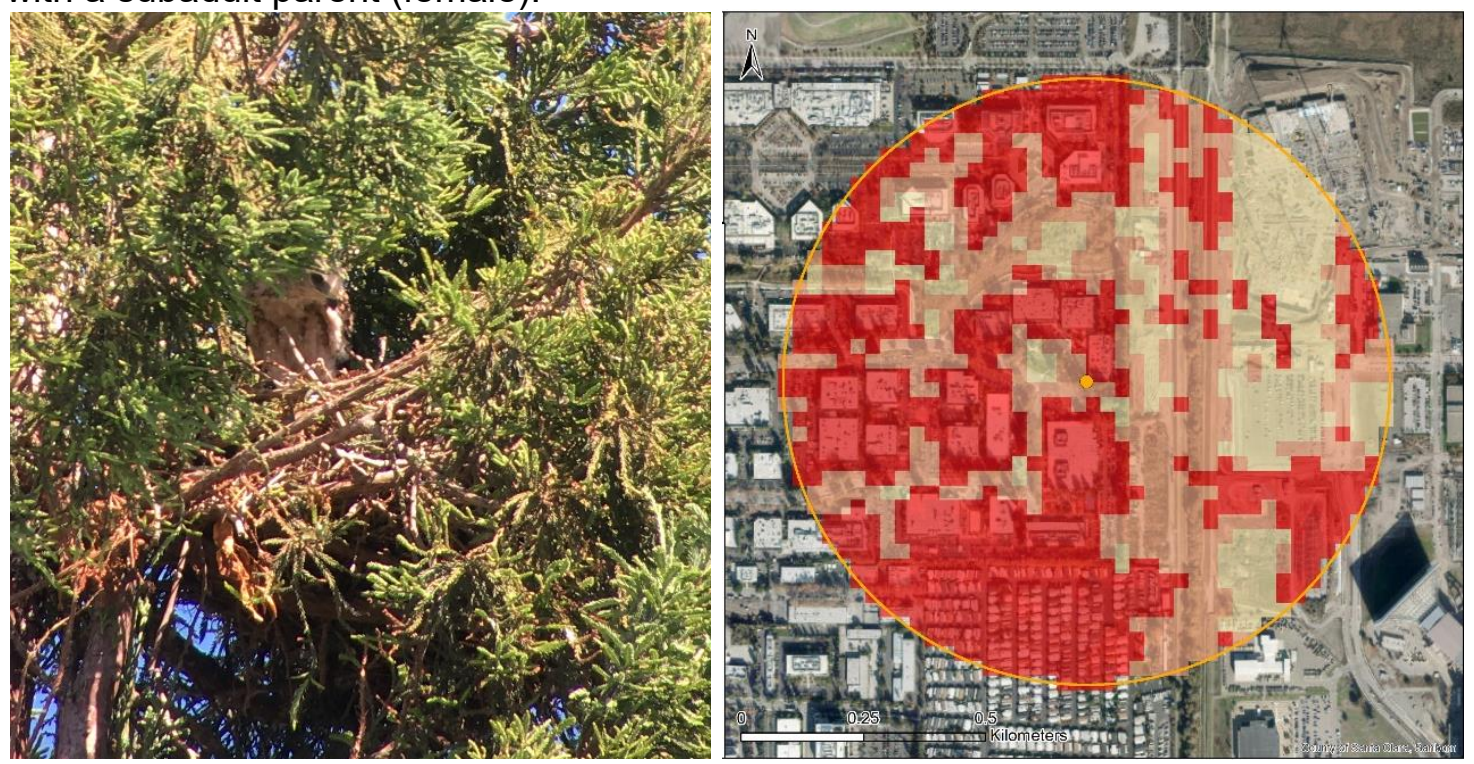
Nest ID: 6

Nest Code: GUAD

Urbanization: URBAN
Location: Near Guadalupe River Park - Coleman Ave., San José

UTM: 10 S 5968654133248

\# chicks fledged: 2

Upland nest in a California fan palm (Washingtonia filifera) leaning over the sidewalk from the parking lot of the Precision Flooring company across from the main entrance to the San José Marketplace. Difficult to observe due to high vehicle traffic and substantial homeless population in the park near the nest.
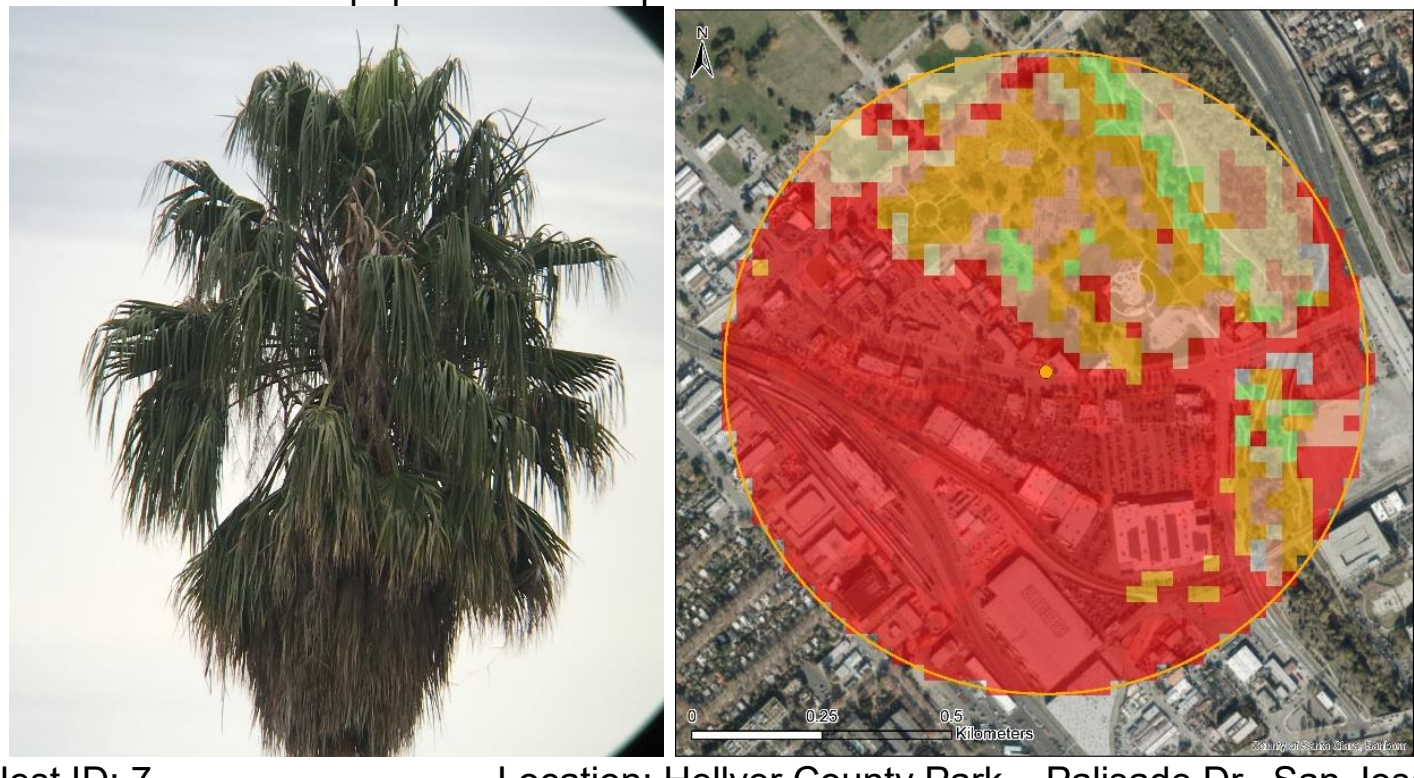

Nest ID: 7

Nest Code: HELL

Urbanization: SUBURBAN
Location: Hellyer County Park - Palisade Dr., San José UTM: 10S 6051094126912

\# chicks fledged: 3

Riparian nest in Eucalyptus sp. on west bank of Coyote Creek very close to Coyote Creek Trail.
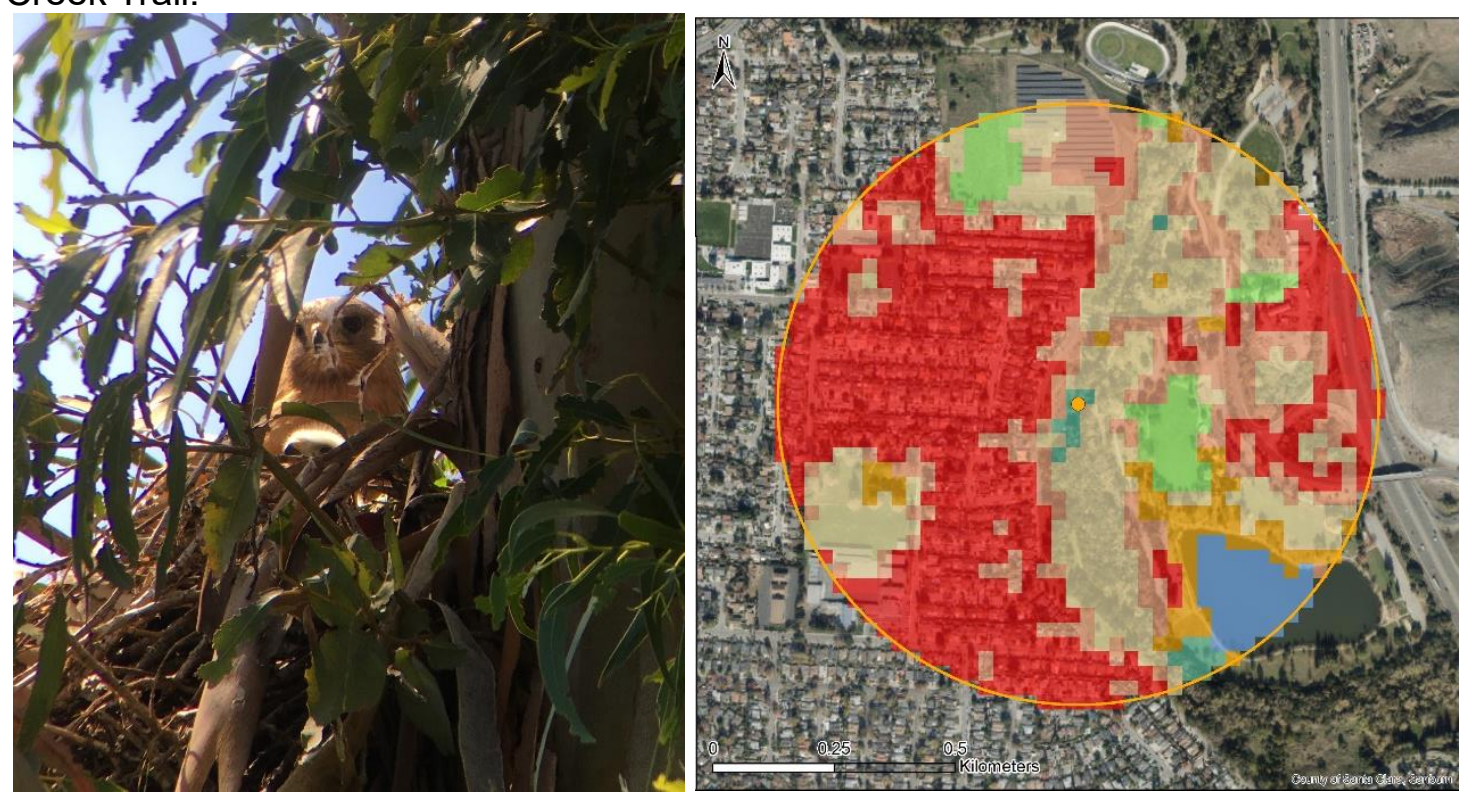
Nest ID: 8

Nest Code: LACC

Urbanization: SUBURBAN
Location: Los Alamitos Creek - Camden Ave. and Mount Forest Dr., San José

UTM: 10S 6016124120140

\# chicks fledged: 2

Upland nest in ash tree (Fraxinus sp.) along the edge of a church parking lot adjacent to a residential backyard. Based on orthoimagery, nest was positioned almost directly over a backyard pool.
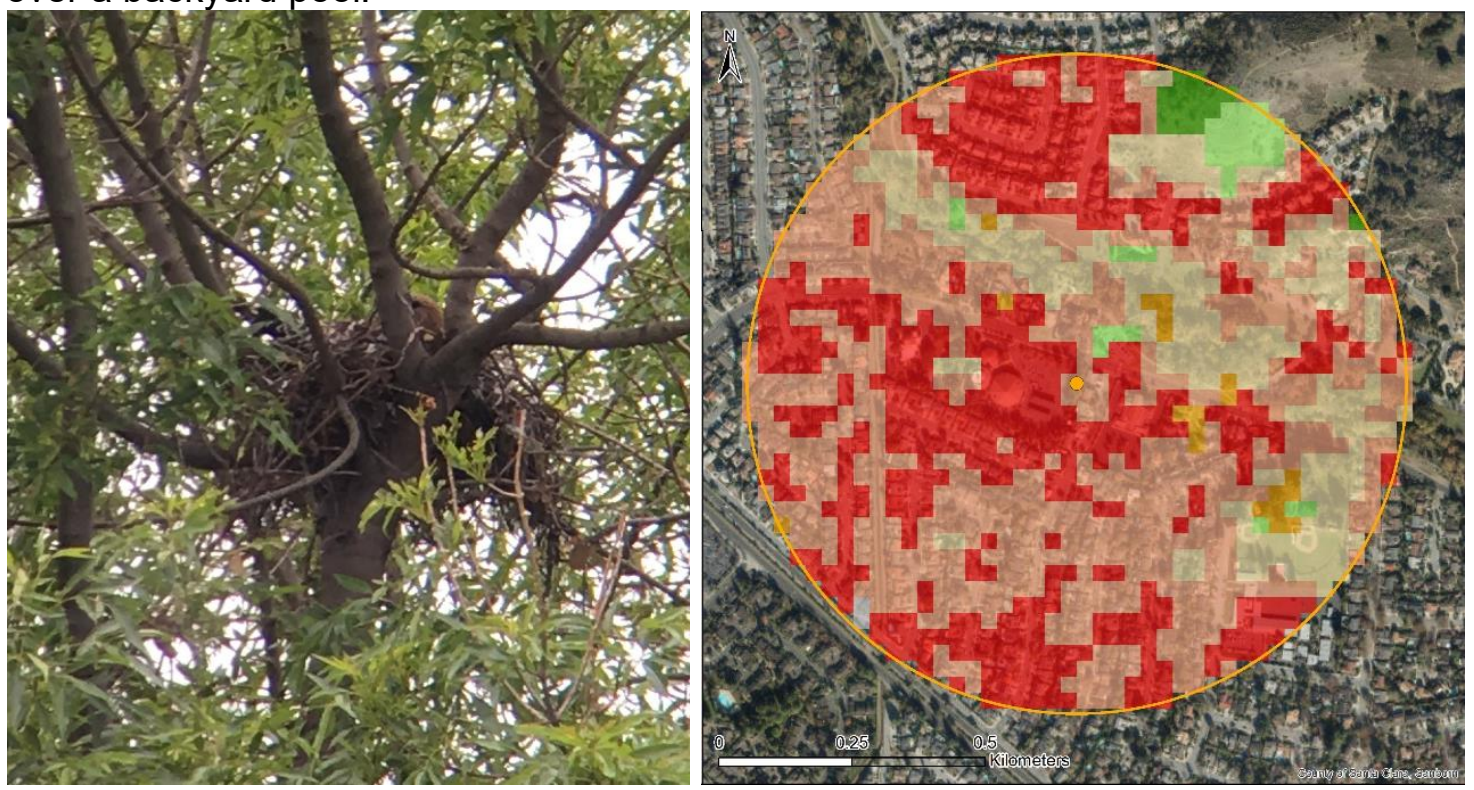

Nest ID: 9

Nest Code: LGCL

Urbanization: URBAN
Location: Los Gatos Creek - Leigh Ave., San José UTM: $10 S 5954654128738$

\# chicks fledged: 2

Riparian nest in ash tree (Fraxinus sp.) in front of a multi-family residential building where Leigh crosses the Los Gatos Creek.
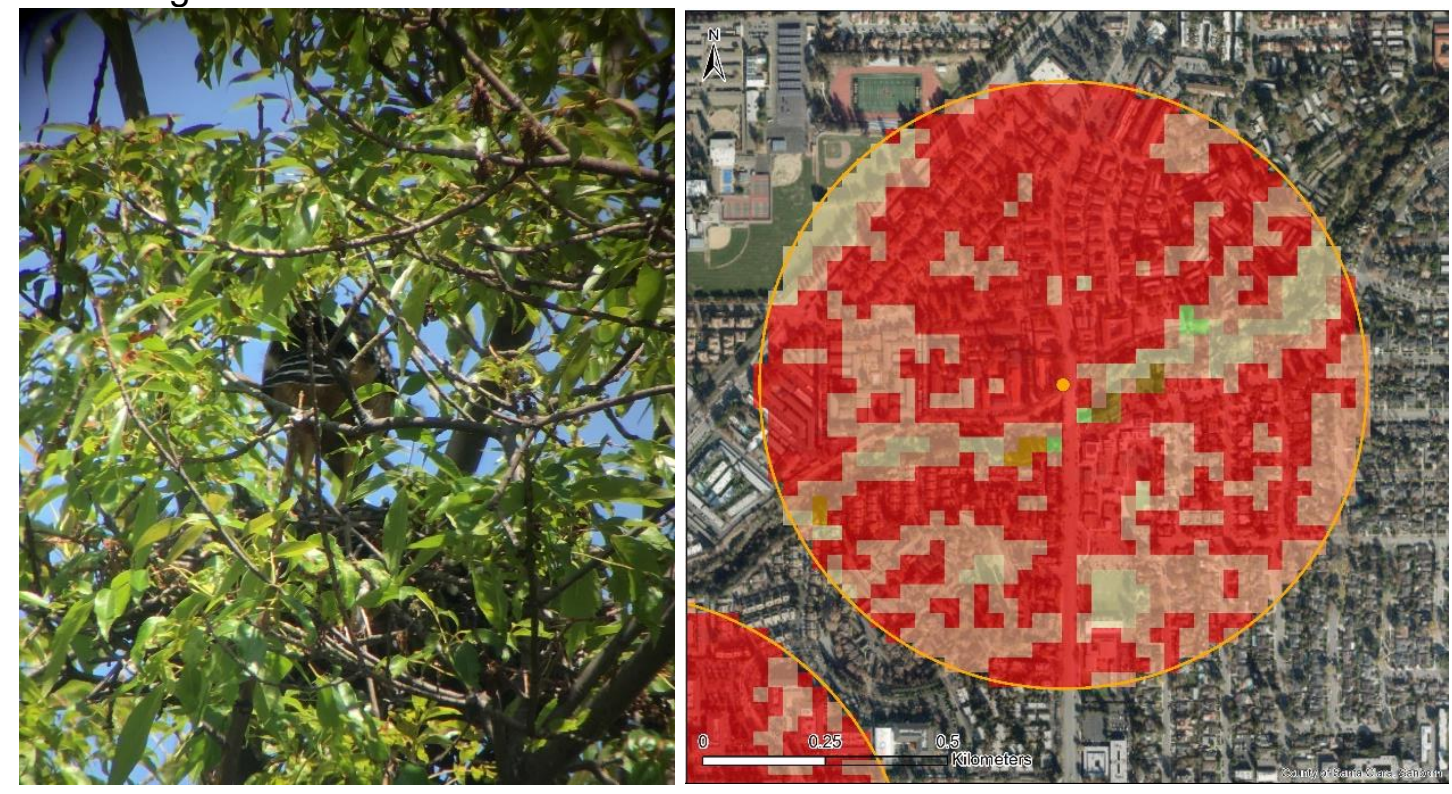
Nest ID: 10

Nest Code: MCCL

Urbanization: SUBURBAN
Location: McClellan Ranch Preserve - McClellan Rd., Cupertino

UTM: 10 S 5831494130195

\# chicks fledged: 1

Riparian nest in western sycamore (Platanus racemosa) north of the $4 \mathrm{H}$ barn along the south bank of Stevens Creek. Well-known nest with many local admirers and Cupertino staff naturalists familiar with the nest and pair.

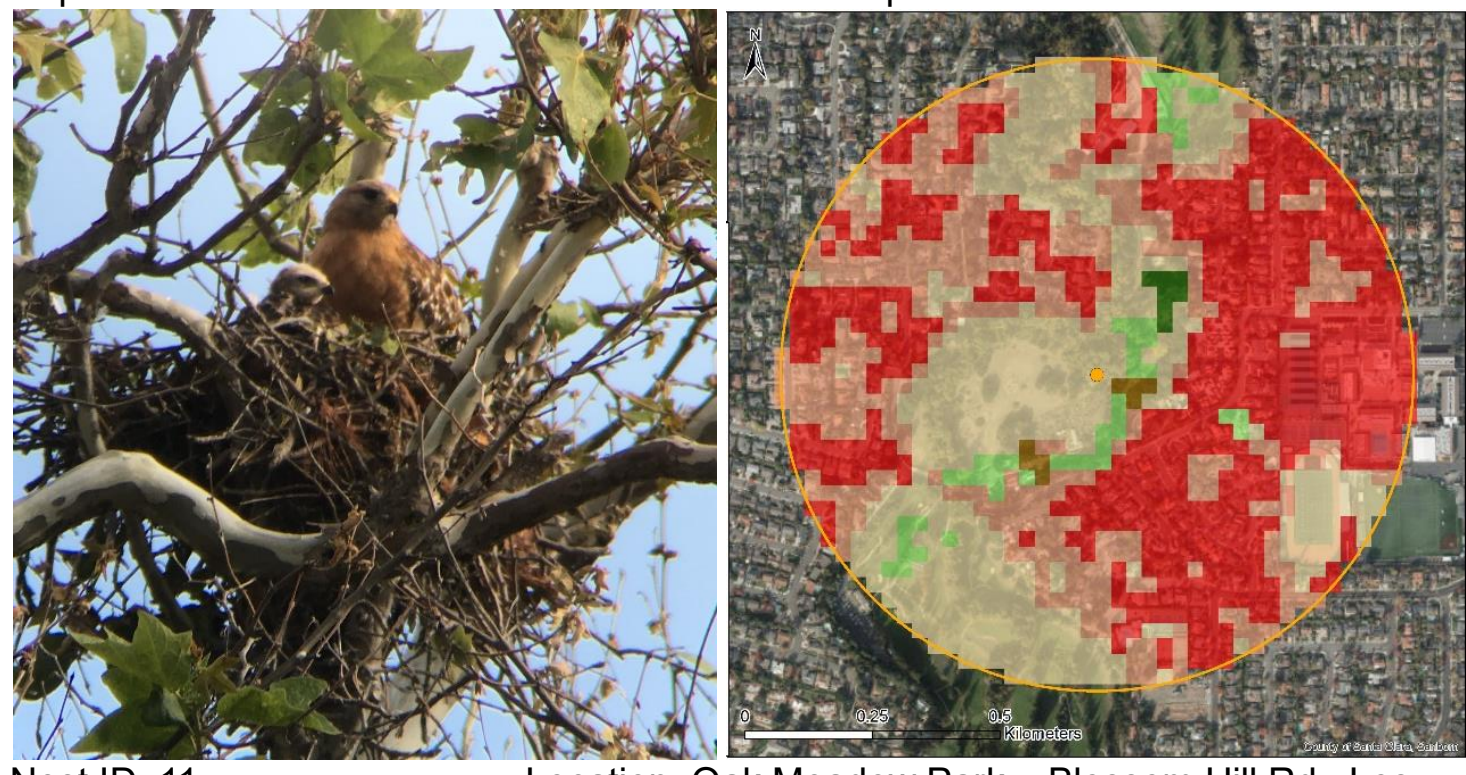

Nest ID: 11

Nest Code: OAME

Location: Oak Meadow Park - Blossom Hill Rd., Los

\section{Urbanization: SUBURBAN}

\section{Gatos}

UTM: 10 S 5910074121360

\# chicks fledged: 2

Riparian nest in Eucalyptus sp. overhanging Blossom Hill Rd. where it crosses the Los Gatos Creek, directly across the street from the parking lot for Oak Meadow Park.
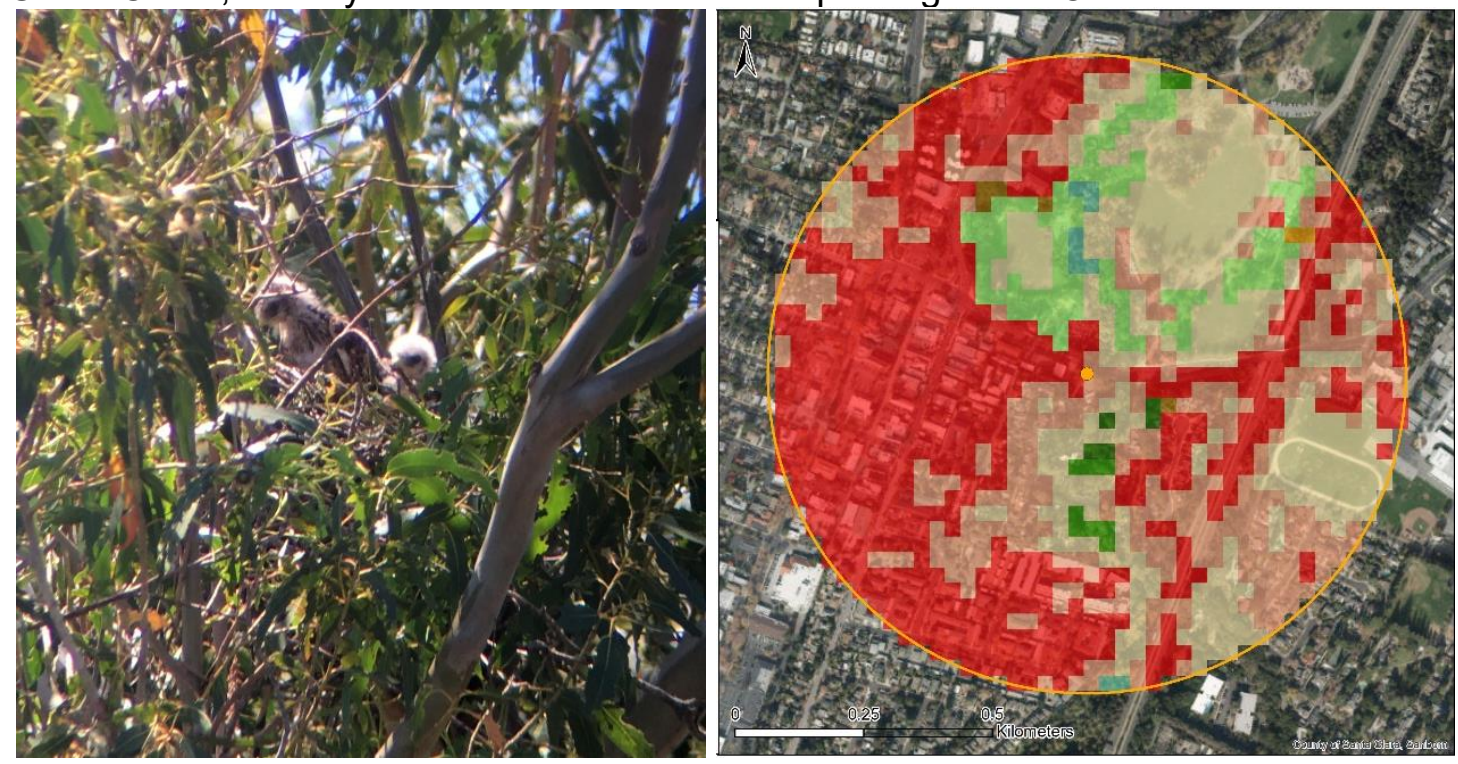
Nest ID: 12

Nest Code: RAWA

Urbanization: SUBURBAN

Riparian nest in a California fan palm (Washingtonia filifera) on the southern end of Raging Waters San José, adjacent to the Lake Cunningham Marina parking lot. Discovered later in the season when nestlings were already fully feathered. Close to Nest 19 but nestling age indicated separate pairs.
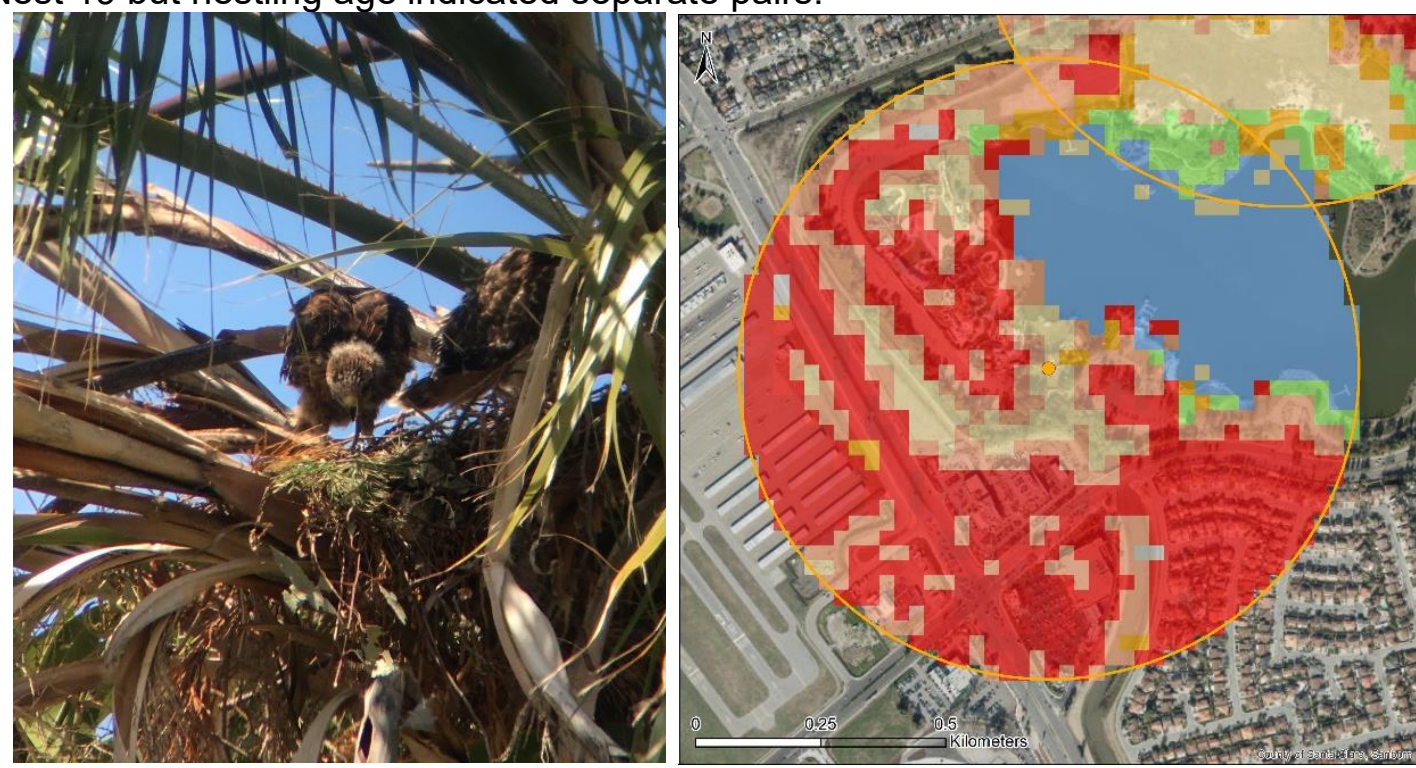

Nest ID: 13

Nest Code: STAN

Urbanization: RURAL

Location: Stanford University - Lake Lagunita, Campus Dr. and Junipero Serra Blvd., Stanford

UTM: $10 \mathrm{~S} 5729434141750$

\# chicks fledged: 3

Upland nest in a Eucalyptus sp. in the parking lot for the Narnia residence halls. Lake Lagunita was partially filled with rainwater creating a small wetland area with breeding amphibians.
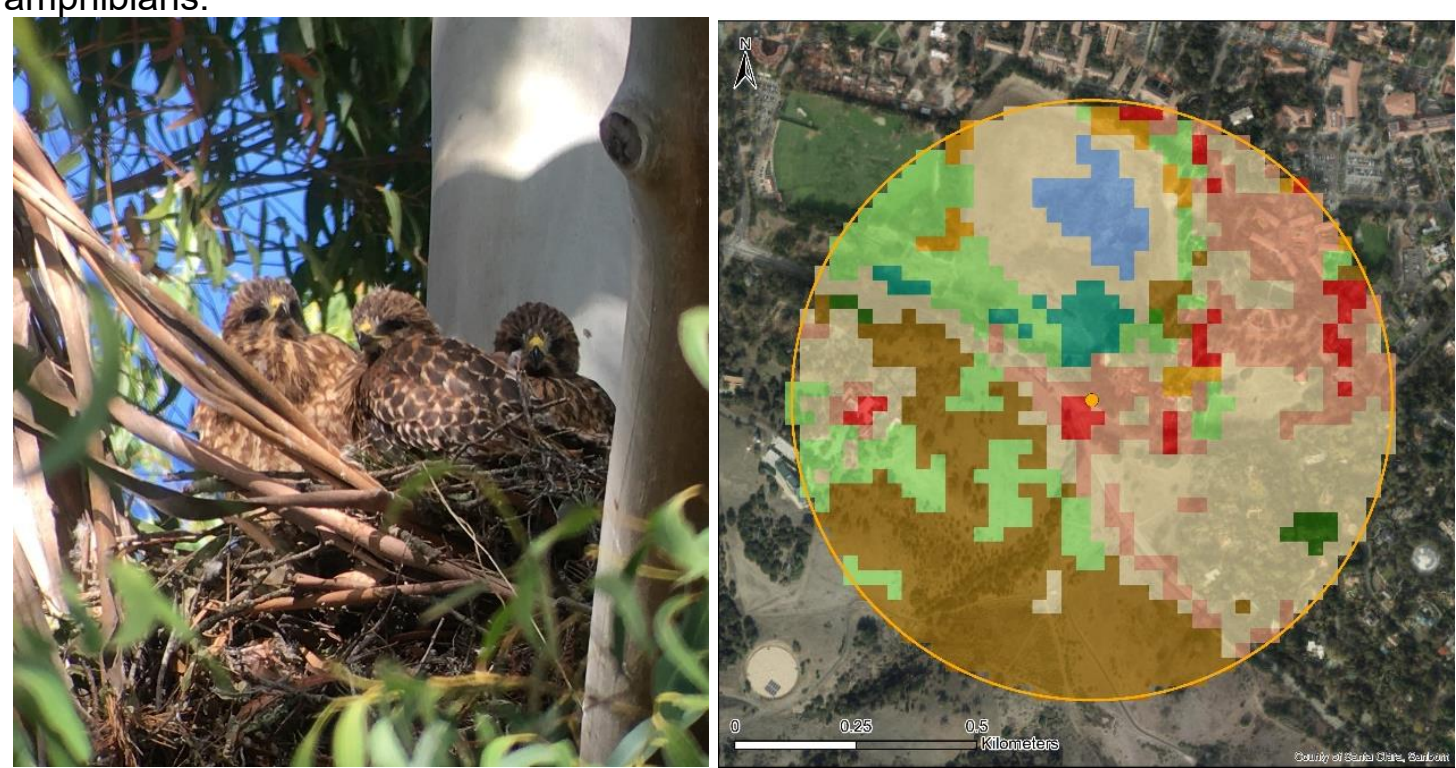
Nest ID: 14

Nest Code: ULIS

Urbanization: SUBURBAN
Location: Ulistac Natural Area - Lick Mill Blvd., Santa Clara

UTM: 10S 5924754140457

\# chicks fledged: 1

Upland nest in a Eucalyptus sp. in the center of the park area. Well-known pair in the birding community.

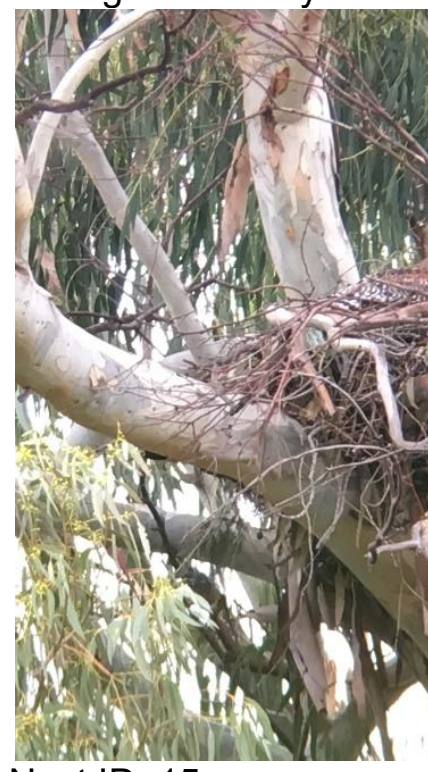

Nest ID: 15

Nest Code: WFBA

Urbanization: URBAN

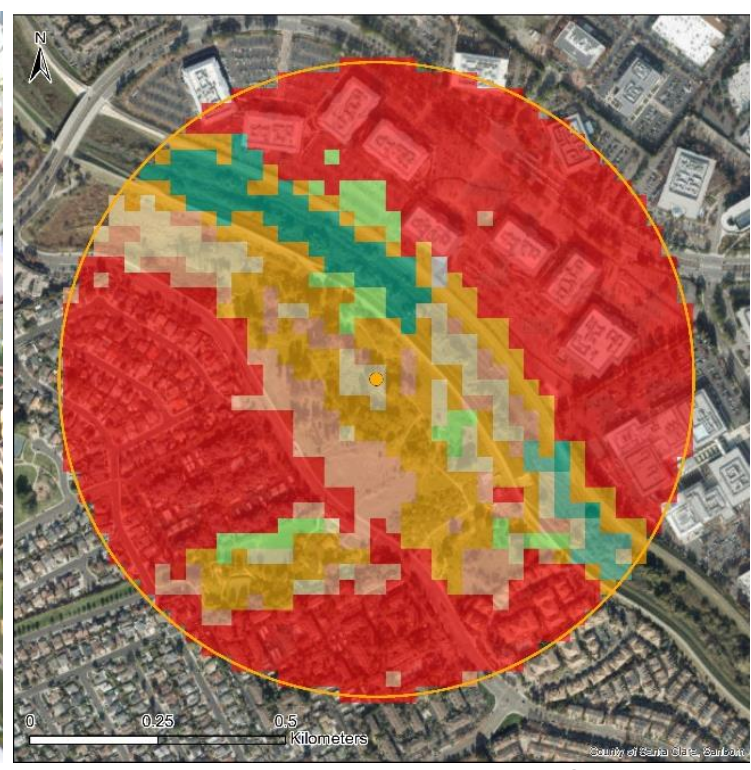

Location: Whole Foods Bascom Ave - 1690 S Bascom Ave., Campbell

UTM: $10 S 5947294127902$

\# chicks fledged: 1

Upland nest in a California fan palm (Washingtonia filifera) in the parking lot directly in front of the Whole Foods entrance. Property managers were aware of the pair and have avoided trimming the palm to allow nesting.
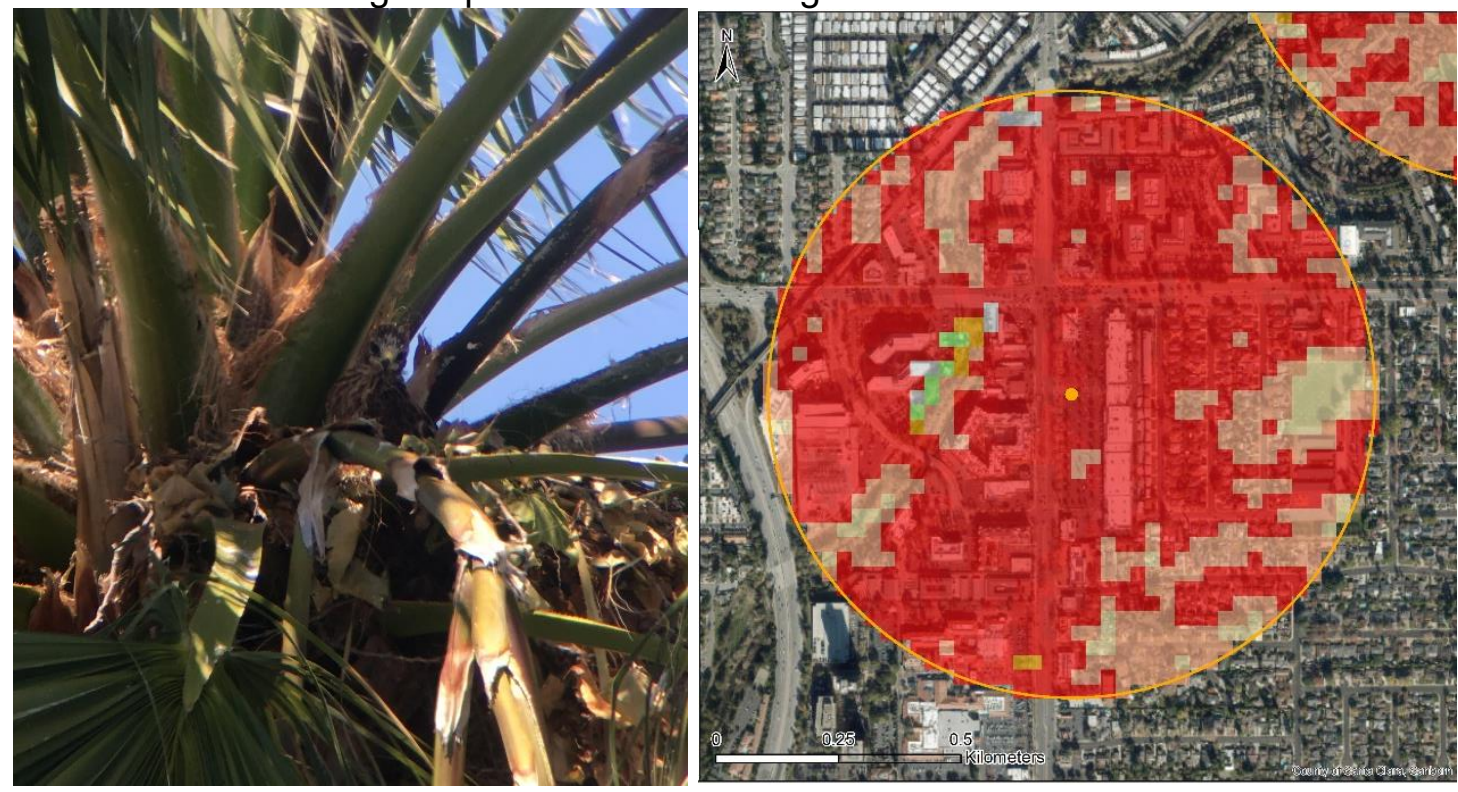
Nest ID: 16

Nest Code: CCCR

Urbanization: RURAL
Location: Coyote Creek Trail - Coyote Ranch, Coyote Ranch Rd., San José

UTM: 10S 6120194119759

\# chicks fledged: 0

Riparian nest in a Fremont cottonwood (Populus fremontii) along Coyote Creek west of the dog club yard. Observed chicks for 1 session only before chicks disappeared; nest remained intact. Noticed that nest platform tilted dramatically in high winds.

Suspected chicks fell from nest. Only nest with amphibian prey observed.

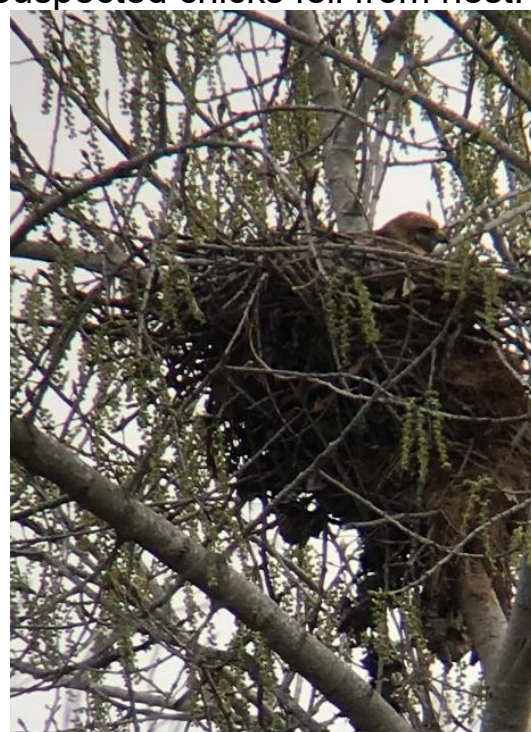

Nest ID: 17

Nest Code: CCAL

Urbanization: RURAL

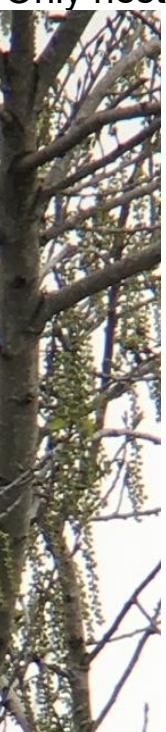

Location: Coyote Creek Trail - Anderson Lake County

Park near Burnett Ave., Morgan Hill

UTM: 10 S 6191844114038

\# chicks fledged: 0

Riparian nest in a western sycamore (Platanus racemosa) along the north bank of Coyote Creek. Nest abandoned late in incubation and no second nest was detected.
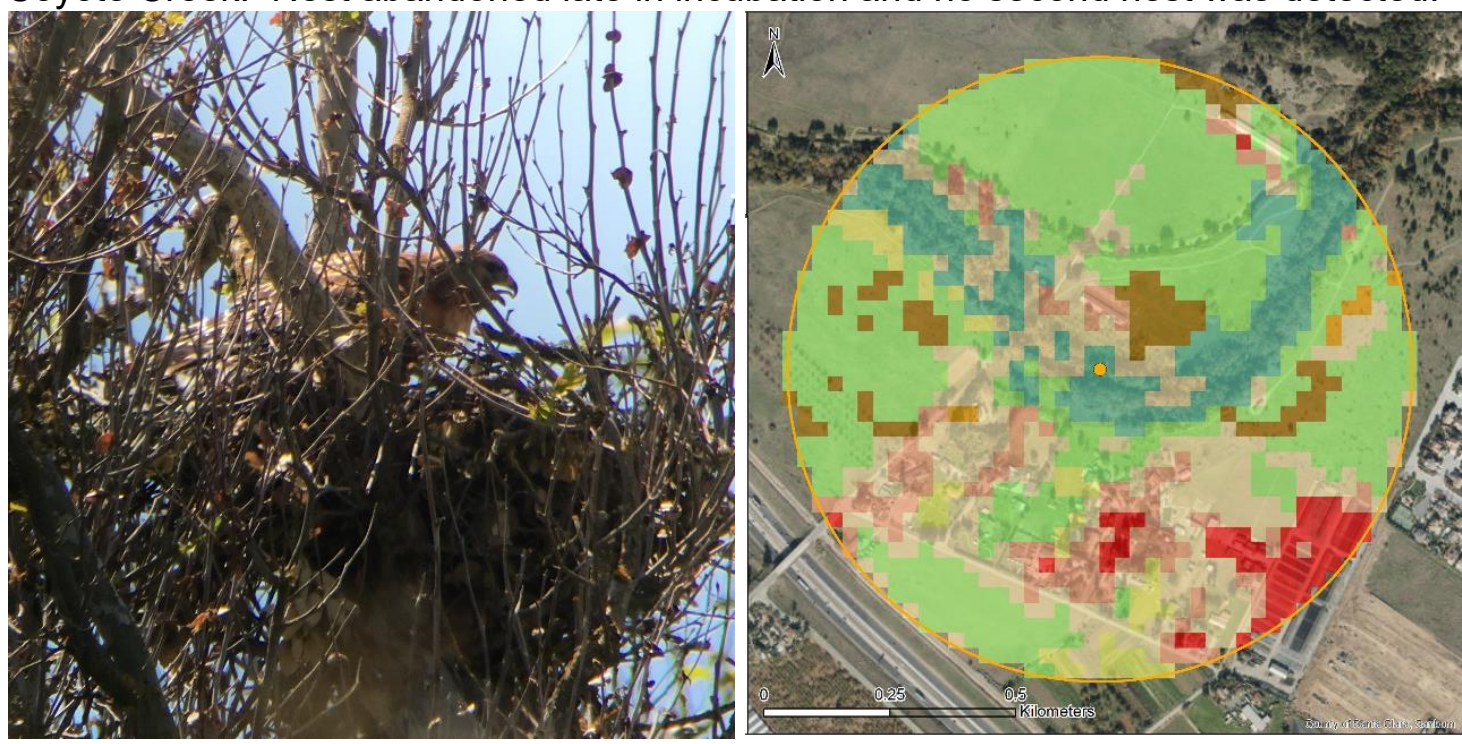
Nest ID: 18

Nest Code: CCGO

Urbanization: RURAL
Location: Coyote Creek Trail - Coyote Creek Golf Dr., Morgan Hill

UTM: 10 S 6147244116820

\# chicks fledged: 0

Riparian nest in a western sycamore (Platanus racemosa) along the west bank of Coyote Creek. Nest abandoned early in incubation and no second nest was detected. Noticed high levels of corvid activity and at least one active American crow (Corvus brachyrhynchos) nest found on later visits to the area.
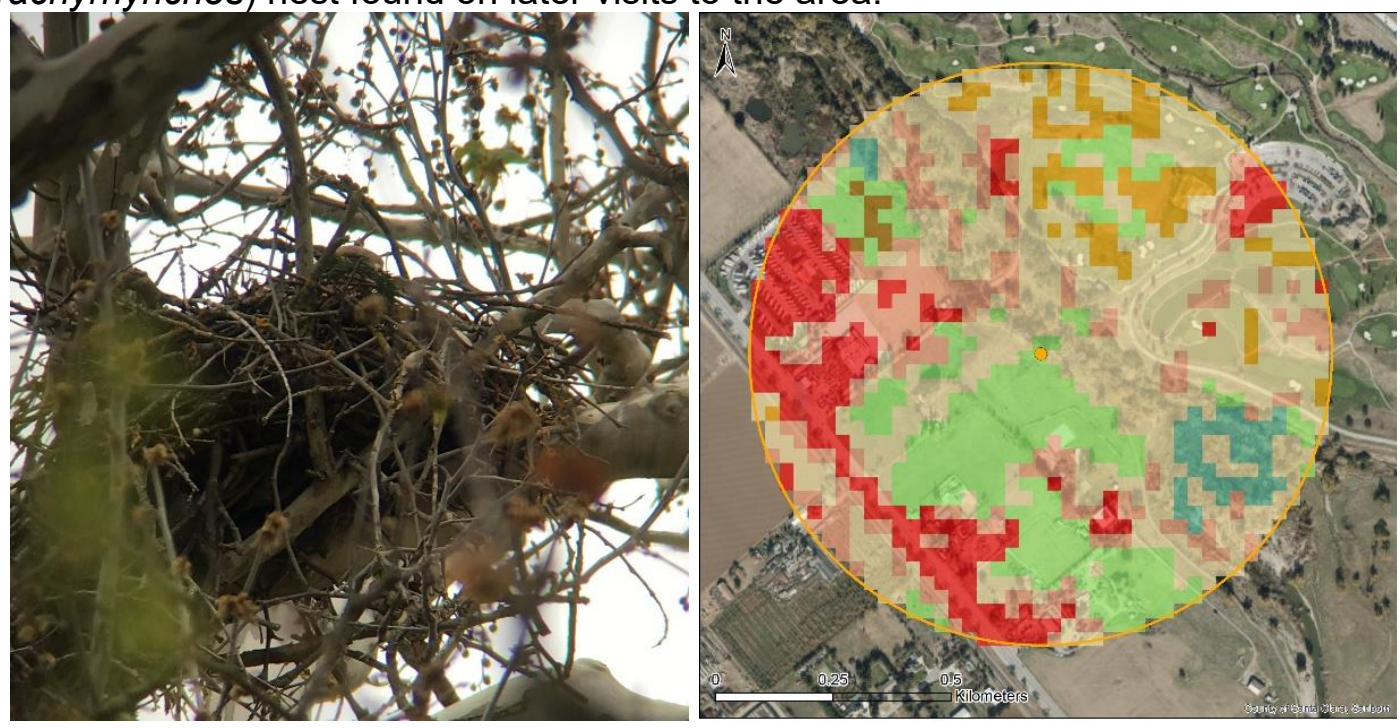

Nest ID: 19

Nest Code: CUNN

Urbanization: SUBURBAN
Location: Lake Cunningham Regional Park Cunningham Ave. and Gana Ct., San José UTM: 10S 6056534133389

\# chicks fledged: 0

Riparian nest in California fan palm (Washingtonia filifera) in the front yard of a singlefamily residence. Entire nest and supporting palm fronds disappeared late in incubation and no second nest was detected. Suspected storm damage. Close to Nest 12 but nestling age indicated separate pairs.
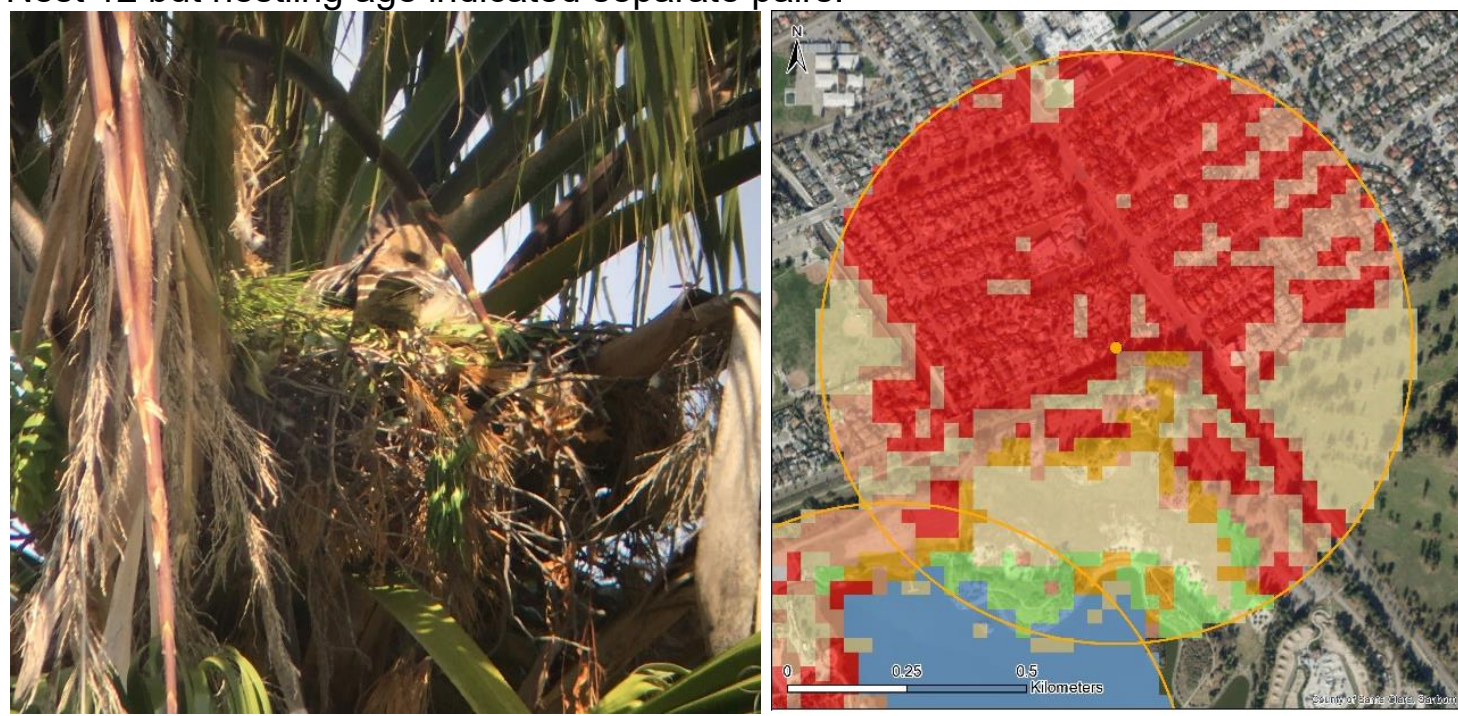


\section{Appendix B: Complete List of Prey Species}

B12.

Observed Prey Species Delivered to Red-shouldered Hawk Nests

\begin{tabular}{|c|c|c|c|c|c|}
\hline Prey item & $\mathrm{N}$ & $\% \mathrm{~N}$ & $\begin{array}{l}\text { Individual } \\
\text { mass }(\mathrm{g})\end{array}$ & $\begin{array}{l}\text { Combined } \\
\text { mass }(\mathrm{g})\end{array}$ & $\begin{array}{c}\% \\
\text { mass }\end{array}$ \\
\hline Class Amphibia & 1 & 0.87 & --- & 500 & 3.57 \\
\hline Bullfrog (Rana catesbeiana) & 1 & 0.87 & $500^{\mathrm{a}}$ & 500 & 3.57 \\
\hline Class Aves & 6 & 5.22 & --- & 359 & 2.57 \\
\hline $\begin{array}{l}\text { House finch } \\
\text { (Haemorhous mexicanus) }\end{array}$ & 1 & 0.87 & $22^{\mathrm{a}}$ & 22 & 0.16 \\
\hline $\begin{array}{l}\text { Dove sp. } \\
\text { (likely Zenaida macroura) }\end{array}$ & 1 & 0.87 & $113^{b}$ & 113 & 0.81 \\
\hline Passerine sp. & 4 & 3.48 & $56^{a}$ & 224 & 1.60 \\
\hline Class Crustacea & 1 & 0.87 & --- & 50 & 0.36 \\
\hline $\begin{array}{l}\text { Red swamp crayfish } \\
\text { (Procambarus clarkii) }\end{array}$ & 1 & 0.87 & $50^{c}$ & 50 & 0.36 \\
\hline Class Mammalia & 58 & 50.43 & --- & 10872 & 77.71 \\
\hline $\begin{array}{l}\text { California ground squirrel } \\
\text { (Spermophilus beechyi) }\end{array}$ & 8 & 6.96 & $300^{d}$ & 2400 & 17.15 \\
\hline $\begin{array}{l}\text { Eastern gray squirrel } \\
\text { (Sciurus carolinensis) }\end{array}$ & 1 & 0.87 & $300^{e}$ & 300 & 2.14 \\
\hline $\begin{array}{l}\text { Eastern fox squirrel } \\
\text { (Sciurus niger) }\end{array}$ & 1 & 0.87 & $354^{\mathrm{e}}$ & 354 & 2.53 \\
\hline Squirrel sp. & 1 & 0.87 & $300^{f}$ & 300 & 2.14 \\
\hline $\begin{array}{l}\text { Botta's pocket gopher } \\
\text { (Thomomys bottae) }\end{array}$ & 3 & 2.61 & $\begin{array}{c}209^{9} \text { large } \\
155^{9} \text { avg }\end{array}$ & 573 & 4.10 \\
\hline $\begin{array}{l}\text { Broad-footed mole } \\
\text { (Scapanus latimanus) }\end{array}$ & 2 & 1.74 & $72^{g}$ & 144 & 1.03 \\
\hline $\begin{array}{l}\text { House mouse } \\
\text { (Mus musculus) }\end{array}$ & 2 & 1.74 & $19^{a}$ & 38 & 0.27 \\
\hline Mouse sp. & 3 & 2.61 & $17^{a}$ & 51 & 0.36 \\
\hline Roof rat (Rattus rattus) & 3 & 2.61 & $\begin{array}{c}350^{9} \text { large } \\
255^{9} \text { avg }\end{array}$ & 860 & 6.15 \\
\hline $\begin{array}{l}\text { Dusky-footed wood rat } \\
\text { (Neotoma fuscipes) }\end{array}$ & 1 & 0.87 & $184^{d}$ & 184 & 1.32 \\
\hline $\begin{array}{l}\text { Rat sp. } \\
\text { (Rattus or Neotoma) }\end{array}$ & 9 & 7.83 & $265^{\mathrm{g}}$ & 2385 & 17.05 \\
\hline $\begin{array}{l}\text { California meadow vole } \\
\text { (Microtus californicus) }\end{array}$ & 1 & 0.87 & $53^{9}$ & 53 & 0.38 \\
\hline Mouse or juvenile rat sp. & 1 & $0 . \varepsilon$ & $40^{h}$ & 40 & 0.29 \\
\hline Mouse or vole sp. & 1 & 0.87 & $30^{\mathrm{h}}$ & 30 & 0.21 \\
\hline
\end{tabular}




\begin{tabular}{|c|c|c|c|c|c|}
\hline Unidentified mammal & 15 & 13.04 & $\begin{array}{l}10^{\mathrm{h}} \text { infant } \\
20^{\mathrm{h}} \text { small } \\
100^{\mathrm{h}} \text { med } \\
300^{\mathrm{h}} \text { large }\end{array}$ & 2330 & 16.65 \\
\hline Class Reptilia & 24 & 20.87 & --- & 1550 & 11.08 \\
\hline $\begin{array}{l}\text { Western fence lizard } \\
\text { (Sceloporus occidentalis) }\end{array}$ & 3 & 2.61 & $17^{a}$ & 51 & 0.36 \\
\hline Alligator lizard (Elgaria sp.) & 8 & 6.96 & $25^{i}$ & 200 & 1.43 \\
\hline Lizard sp. & 6 & 5.22 & $17^{a}$ & 102 & 0.73 \\
\hline $\begin{array}{l}\text { Gopher snake } \\
\text { (Pituophus catenifer) }\end{array}$ & 1 & 0.87 & $202^{a}$ & 202 & 1.44 \\
\hline $\begin{array}{l}\text { California kingsnake } \\
\text { (Lampropeltis getula) }\end{array}$ & 1 & 0.87 & $226^{j}$ & 226 & 1.62 \\
\hline $\begin{array}{l}\text { Ring-necked snake } \\
\text { (Diadophis punctatus) }\end{array}$ & 1 & 0.87 & $9^{k}$ & 9 & 0.06 \\
\hline Medium snake sp. & 4 & 3.48 & $190^{\mathrm{a}}$ & 760 & 5.43 \\
\hline Unidentified & 25 & 21.74 & --- & 660 & 4.72 \\
\hline Unidentified prey & 25 & 21.74 & $20^{\mathrm{h}}$ & 660 & 4.72 \\
\hline Total & 115 & 100 & --- & 13991 & 100 \\
\hline
\end{tabular}

Note. Data compiled from prey deliveries to 16 red-shouldered hawk nests in 2019 in Santa Clara County, CA. Prey mass was assigned based on the apparent full size of the prey item, not the portion delivered to the nest, if different. $\mathrm{N}=$ number of individuals, $\% \mathrm{~N}=$ percent frequency of prey, individual mass $=$ estimated biomass of a single individual $(\mathrm{g})$, combined mass $=$ estimated biomass of all individuals combined $(\mathrm{g})$, and $\%$ mass $=$ percent of total biomass contributed by all individuals of a prey species.

a Steenhof (1983). ' B Braun, Tomlinson, \& Wann (2015). c Olouch (1990); Nagy, Fusaro, Conard, \& Morningstar (2019). d All juveniles, calculated as lowest value from mass range in Jameson \& Peeters (2004). e All juveniles, calculated as $60 \%$ of small adult mass in Jameson \& Peeters (2004) based on personal experience. ${ }^{\dagger}$ All juveniles, based on comparison with known juvenile squirrel species. ${ }^{\mathrm{g}}$ Jameson \& Peeters (2004). ${ }^{\mathrm{h}}$ Based on observed size in relation to mass of known prey items. ' Kingsbury (1995). ' Based on comparative observed size and reported mass of similarly sized species Pituophus catenifer in Stebbins \& McGinnis (2012) and Steenhof (1983). ${ }^{k}$ Based on comparative observed size and reported mass of similarly sized species Sonora semiannulata in Stebbins \& McGinnis (2012) and Steenhof (1983). 


\section{Appendix C: Complete List of External Activity}

C13.

Observed External Activity at Red-shouldered Hawk Nests

\begin{tabular}{|c|c|c|c|}
\hline $\begin{array}{c}\text { External activity } \\
\text { type/code }\end{array}$ & $\mathrm{N}$ & $\% \mathrm{~N}$ & Activity definition \\
\hline Human activity & 5446 & 92.97 & $\begin{array}{l}\text { Total activities from anthropogenic } \\
\text { sources }\end{array}$ \\
\hline Aircraft & 115 & 1.96 & $\begin{array}{l}\text { Any plane/helicopter passing low } \\
\text { enough to generate noticeable } \\
\text { noise }\end{array}$ \\
\hline HELICOPTER & 15 & 0.26 & Helicopter flying overhead \\
\hline PLANE & 100 & 1.71 & Low-flying airplane \\
\hline Cyclist & 1823 & 31.12 & Cyclist of any kind \\
\hline CYC & 1817 & 31.02 & Person on bike \\
\hline $\mathrm{CYC}+\mathrm{DOG}$ & 6 & 0.10 & Cyclist with dog running alongside \\
\hline Dog & 257 & 4.39 & Domestic canine \\
\hline DOG & 257 & 4.39 & $\begin{array}{l}\text { Presence of a dog and human } \\
\text { together }\end{array}$ \\
\hline Equipment & 21 & 0.36 & $\begin{array}{l}\text { Large motorized trailer/ equipment/ } \\
\text { construction vehicle }\end{array}$ \\
\hline BIGRIG & 2 & 0.03 & $\begin{array}{l}\text { Tractor trailer generating excessive } \\
\text { noise beyond normal traffic noise }\end{array}$ \\
\hline CATTLE TRAILER & 1 & 0.02 & Rattling empty cattle trailer \\
\hline CONSTRUCTION & 8 & 0.14 & Construction noise \\
\hline FARM TOOLS & 2 & 0.03 & Clattering noise from hand tools \\
\hline GARBAGE TRUCK & 2 & 0.03 & $\begin{array}{l}\text { Noise associated with garbage } \\
\text { truck }\end{array}$ \\
\hline MACHINE & 3 & 0.05 & Noise of machinery \\
\hline TRACTOR & 3 & 0.05 & Earthmoving equipment \\
\hline Noise & 189 & 3.23 & Any noise disturbance \\
\hline CARALARM & 4 & 0.07 & Car alarm sound \\
\hline CARTCOLLECT & 4 & 0.07 & Activity of collecting shopping carts \\
\hline CARTRUNK & 1 & 0.02 & Loud slamming of car trunk door \\
\hline DELIVERIES & 4 & 0.07 & $\begin{array}{l}\text { Van stopping and idling; noise of } \\
\text { rollup door, pallets } \\
\text { loaded/unloaded }\end{array}$ \\
\hline DOGBARK & 12 & 0.20 & Dog barking \\
\hline CVINT & 1 & 0.02 & $\begin{array}{l}\text { PA system audible outside of } \\
\text { venue }\end{array}$ \\
\hline HONK & 22 & 0.38 & Car honk \\
\hline ICE CREA & 2 & 0.03 & Jingling of ice cream cart \\
\hline
\end{tabular}




\begin{tabular}{|c|c|c|c|}
\hline LEAFBLOWER & 1 & 0.02 & Noise of leaf-blowing machine \\
\hline MAIL CARRIER & 1 & 0.02 & $\begin{array}{l}\text { Postal worker delivering along mail } \\
\text { route }\end{array}$ \\
\hline MOTORCYCLE & 2 & 0.03 & Motorcycle revving \\
\hline MOWER & 8 & 0.14 & $\begin{array}{l}\text { Noise from lawnmower (motorized } \\
\text { push mower or riding lawnmower) }\end{array}$ \\
\hline MUSIC & 5 & 0.09 & Loud music \\
\hline NOISE & 5 & 0.09 & $\begin{array}{l}\text { Road noise carrying from outside } \\
\text { disturbance area }\end{array}$ \\
\hline PA SYS & 3 & 0.05 & $\begin{array}{l}\text { Human voice broadcast on PA } \\
\text { system }\end{array}$ \\
\hline PARTY & 1 & 0.02 & $\begin{array}{l}\text { College dorm party with loud music } \\
\text { audible outside of residence hall }\end{array}$ \\
\hline PICNIC & 3 & 0.05 & Picnic at park, talking, kids yelling \\
\hline PLAYGROUND & 2 & 0.03 & Kids yelling, talking, screaming \\
\hline SHOUT & 8 & 0.14 & Shouting, yelling, shrieking \\
\hline SIREN & 2 & 0.03 & Emergency vehicle siren \\
\hline TIRE SCREECH & 3 & 0.05 & Screeching tires \\
\hline TRAIN & 4 & 0.07 & $\begin{array}{l}\text { Train passing within visible or } \\
\text { audible distance from nest, no } \\
\text { horn/whistle used }\end{array}$ \\
\hline TRAIN WHISTLE & 37 & 0.63 & Train whistle audible near nest \\
\hline TRASH CAN FLAP & 5 & 0.09 & $\begin{array}{l}\text { Slamming a spring-hinged trash } \\
\text { can flap }\end{array}$ \\
\hline TRUCK BEEP & 2 & 0.03 & Truck reverse beeping \\
\hline VAN & 41 & 0.70 & $\begin{array}{l}\text { Delivery van stopping or idling, no } \\
\text { offloading noise }\end{array}$ \\
\hline WEEDWHACKER & 6 & 0.10 & Sound of a weedwhacker in use \\
\hline Pedestrian & 2978 & 50.84 & Any human on foot \\
\hline JOG & 263 & 4.49 & Person jogging or running \\
\hline NATURALIST CLASS & 50 & 0.85 & $\begin{array}{l}\text { Class of approx. } 20 \text { kids on a park } \\
\text { walkthrough; shouting, talking }\end{array}$ \\
\hline PAC & 575 & 9.82 & $\begin{array}{l}\text { Person at car (getting in/out, } \\
\text { driving in/out, parking/pulling out) }\end{array}$ \\
\hline PHOTOGRAPHER & 1 & 0.02 & $\begin{array}{l}\text { Photographer presence close to } \\
\text { nest }\end{array}$ \\
\hline ROLLERBLADER & 11 & 0.19 & Person on rollerblades \\
\hline RSCHR & 5 & 0.09 & Researcher moving \\
\hline STROLLER & 38 & 0.65 & Baby stroller pushed by person \\
\hline WALK & 2022 & 34.52 & Person walking \\
\hline YARD PLAY & 5 & 0.09 & Kids and parents in front yard \\
\hline YARDWORK & 8 & 0.14 & Garden work in residential yard \\
\hline Vehicle & 63 & 1.08 & Any non-car vehicle \\
\hline GOLFCART & 5 & 0.09 & Golf cart \\
\hline
\end{tabular}




\begin{tabular}{|c|c|c|c|}
\hline KID BIKE & 4 & 0.07 & $\begin{array}{l}\text { Small motorized motorcycle for } \\
\text { kids }\end{array}$ \\
\hline KID CAR & 2 & 0.03 & Small motorized car for kids \\
\hline MOTOR WORK CART & 1 & 0.02 & Golf cart with noisy motor \\
\hline SCOOTER & 15 & 0.26 & $\begin{array}{l}\text { Person riding electric or push } \\
\text { scooter }\end{array}$ \\
\hline SKT & 28 & 0.48 & Skateboarder \\
\hline WHEELCHAIR & 8 & 0.14 & Person in wheelchair \\
\hline Natural activity & 412 & 7.03 & $\begin{array}{l}\text { Total disturbances from natural } \\
\text { sources }\end{array}$ \\
\hline Crow alarm & 12 & 0.20 & American crow alarm call \\
\hline AMCR ALARM & 12 & 0.20 & American crow alarm call \\
\hline Conspecific & 221 & 3.77 & Adult red-shouldered hawk \\
\hline MATE VISIT & 35 & 0.60 & $\begin{array}{l}\text { Mate of nesting hawk perched near } \\
\text { nest }\end{array}$ \\
\hline RSHA CALL & 170 & 2.90 & Red-shouldered hawk calling \\
\hline RSHA FLYBY & 16 & 0.27 & $\begin{array}{l}\text { Red-shouldered hawk flying near } \\
\text { nest }\end{array}$ \\
\hline Corvid & 27 & 0.46 & Crow or raven presence \\
\hline AMCR & 20 & 0.34 & American crow \\
\hline CORA & 7 & 0.12 & Common raven \\
\hline Squirrel & 2 & 0.03 & Eastern gray squirrel in nest tree \\
\hline EGSQ & 2 & 0.03 & Eastern gray squirrel in nest tree \\
\hline Other avian & 102 & 1.74 & $\begin{array}{l}\text { Any other avian species, non- } \\
\text { raptor }\end{array}$ \\
\hline BUSH & 2 & 0.03 & Bushtit \\
\hline CANG & 34 & 0.58 & Canada goose \\
\hline GBHE & 3 & 0.05 & Great blue heron \\
\hline GULLS & 42 & 0.72 & Gull sp. \\
\hline HOOR & 2 & 0.03 & Hooded oriole \\
\hline HUMMER & 2 & 0.03 & Hummingbird sp. \\
\hline NOMO & 3 & 0.05 & Northern mockingbird \\
\hline TUVU & 14 & 0.24 & Turkey vulture \\
\hline Predator & 2 & 0.03 & Mammalian predator \\
\hline BOBCAT & 1 & 0.02 & Bobcat \\
\hline COYOTE & 1 & 0.02 & Coyote \\
\hline Rain & 38 & 0.65 & Precipitation \\
\hline LIGHT RAIN & 13 & 0.22 & Rain - light \\
\hline LIGHT-MOD RAIN & 7 & 0.12 & Rain - light to moderate \\
\hline MODERATE RAIN & 10 & 0.17 & Rain - moderate to heavy \\
\hline HEAVY RAIN & 8 & 0.14 & Rain - heavy \\
\hline Other raptor & 8 & 0.14 & Any other raptor species presence \\
\hline $\mathrm{COHA}$ & 3 & 0.05 & Cooper's hawk \\
\hline OSPR & 2 & 0.03 & Osprey \\
\hline
\end{tabular}




\begin{tabular}{lccl} 
RTHA & 2 & 0.03 & Red-tailed hawk \\
WTKI & 1 & 0.02 & White-tailed kite \\
\hline Total & 5858 & 100.00 & All external activities \\
\hline Note. List of all external activities observed at 16 red-shouldered hawk nests in \\
2019 in Santa Clara County, CA. Uppercase row headings indicate the code \\
used in the field for data collection; sentence case row headings indicate broader \\
categories used for data analysis. $\mathrm{N}=$ number of observed activities of a given \\
type, \% N = activities of a given type as a percentage of all activities observed.
\end{tabular}




\section{Appendix D: National Land Cover Database Descriptions}

D14.

Land Cover Types from the 2016 National Land Cover Database

\begin{tabular}{|c|c|}
\hline Classivalue & Classification description \\
\hline \multicolumn{2}{|l|}{ Water } \\
\hline 11 & $\begin{array}{l}\text { Open Water- areas of open water, generally with less } \\
\text { than } 25 \% \text { cover of vegetation or soil. }\end{array}$ \\
\hline 12 & $\begin{array}{l}\text { Perennial Ice/Snow- areas characterized by a perennial } \\
\text { cover of ice and/or snow, generally greater than } 25 \% \text { of } \\
\text { total cover. }\end{array}$ \\
\hline \multicolumn{2}{|r|}{ 然 } \\
\hline 21 & $\begin{array}{l}\text { Developed, Open Space- areas with a mixture of some } \\
\text { constructed materials, but mostly vegetation in the form } \\
\text { of lawn grasses. Impervious surfaces account for less } \\
\text { than } 20 \% \text { of total cover. These areas most commonly } \\
\text { include large-lot single-family housing units, parks, golf } \\
\text { courses, and vegetation planted in developed settings for } \\
\text { recreation, erosion control, or aesthetic purposes. }\end{array}$ \\
\hline 22 & $\begin{array}{l}\text { Developed, Low Intensity- areas with a mixture of } \\
\text { constructed materials and vegetation. Impervious } \\
\text { surfaces account for } 20 \% \text { to } 49 \% \text { percent of total cover. } \\
\text { These areas most commonly include single-family } \\
\text { housing units. }\end{array}$ \\
\hline 23 & $\begin{array}{l}\text { Developed, Medium Intensity -areas with a mixture of } \\
\text { constructed materials and vegetation. Impervious } \\
\text { surfaces account for } 50 \% \text { to } 79 \% \text { of the total cover. } \\
\text { These areas most commonly include single-family } \\
\text { housing units. }\end{array}$ \\
\hline 24 & $\begin{array}{l}\text { Developed High Intensity-highly developed areas where } \\
\text { people reside or work in high numbers. Examples include } \\
\text { apartment complexes, row houses and } \\
\text { commercial/industrial. Impervious surfaces account for } \\
80 \% \text { to } 100 \% \text { of the total cover. }\end{array}$ \\
\hline
\end{tabular}

Barren

31

Barren Land (Rock/Sand/Clay) - areas of bedrock, desert pavement, scarps, talus, slides, volcanic material, glacial debris, sand dunes, strip mines, gravel pits and other accumulations of earthen material. Generally, vegetation accounts for less than $15 \%$ of total cover. 
Forest

41

42

43

Shrubland

51

52

Herbaceous

71

72

73

74
Deciduous Forest- areas dominated by trees generally greater than 5 meters tall, and greater than $20 \%$ of total vegetation cover. More than $75 \%$ of the tree species shed foliage simultaneously in response to seasonal change.

Evergreen Forest- areas dominated by trees generally greater than 5 meters tall, and greater than $20 \%$ of total vegetation cover. More than $75 \%$ of the tree species maintain their leaves all year. Canopy is never without green foliage.

Mixed Forest- areas dominated by trees generally greater than 5 meters tall, and greater than $20 \%$ of total vegetation cover. Neither deciduous nor evergreen species are greater than $75 \%$ of total tree cover.

Dwarf Scrub- Alaska only areas dominated by shrubs less than 20 centimeters tall with shrub canopy typically greater than $20 \%$ of total vegetation. This type is often co-associated with grasses, sedges, herbs, and nonvascular vegetation.

Shrub/Scrub- areas dominated by shrubs; less than 5 meters tall with shrub canopy typically greater than $20 \%$ of total vegetation. This class includes true shrubs, young trees in an early successional stage or trees stunted from environmental conditions.

Grassland/Herbaceous- areas dominated by gramanoid or herbaceous vegetation, generally greater than $80 \%$ of total vegetation. These areas are not subject to intensive management such as tilling, but can be utilized for grazing.

Sedge/Herbaceous- Alaska only areas dominated by sedges and forbs, generally greater than $80 \%$ of total vegetation. This type can occur with significant other grasses or other grass like plants, and includes sedge tundra, and sedge tussock tundra.

Lichens- Alaska only areas dominated by fruticose or foliose lichens generally greater than $80 \%$ of total vegetation.

Moss- Alaska only areas dominated by mosses, generally greater than $80 \%$ of total vegetation. 
Planted/ Cultivated

81

Pasture/Hay-areas of grasses, legumes, or grass-legume mixtures planted for livestock grazing or the production of seed or hay crops, typically on a perennial cycle.

Pasture/hay vegetation accounts for greater than $20 \%$ of total vegetation.

82

Cultivated Crops -areas used for the production of annual crops, such as corn, soybeans, vegetables, tobacco, and cotton, and also perennial woody crops such as orchards and vineyards. Crop vegetation accounts for greater than $20 \%$ of total vegetation. This

Wetlands class also includes all land being actively tilled.

90

Woody Wetlands- areas where forest or shrubland vegetation accounts for greater than $20 \%$ of vegetative cover and the soil or substrate is periodically saturated with or covered with water.

95 Emergent Herbaceous Wetlands- Areas where perennial herbaceous vegetation accounts for greater than $80 \%$ of vegetative cover and the soil or substrate is periodically saturated with or covered with water.

Note. Land cover descriptions are based on the Anderson Land Cover Classification System (MRLC, n.d.). 


\section{Appendix E: R Code for Data Analysis}

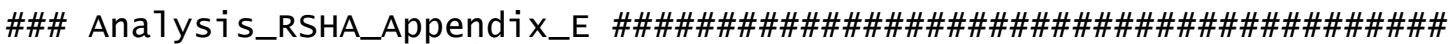
\# Last Updated: 08 Apri 12020

\# R version 3.6.3 "Holding the windsock" (for windows)

\# RStudio Desktop version 1.2.5033 (for windows)

\# This R Script is a compilation of all code used for statistical analyses in this thesis.

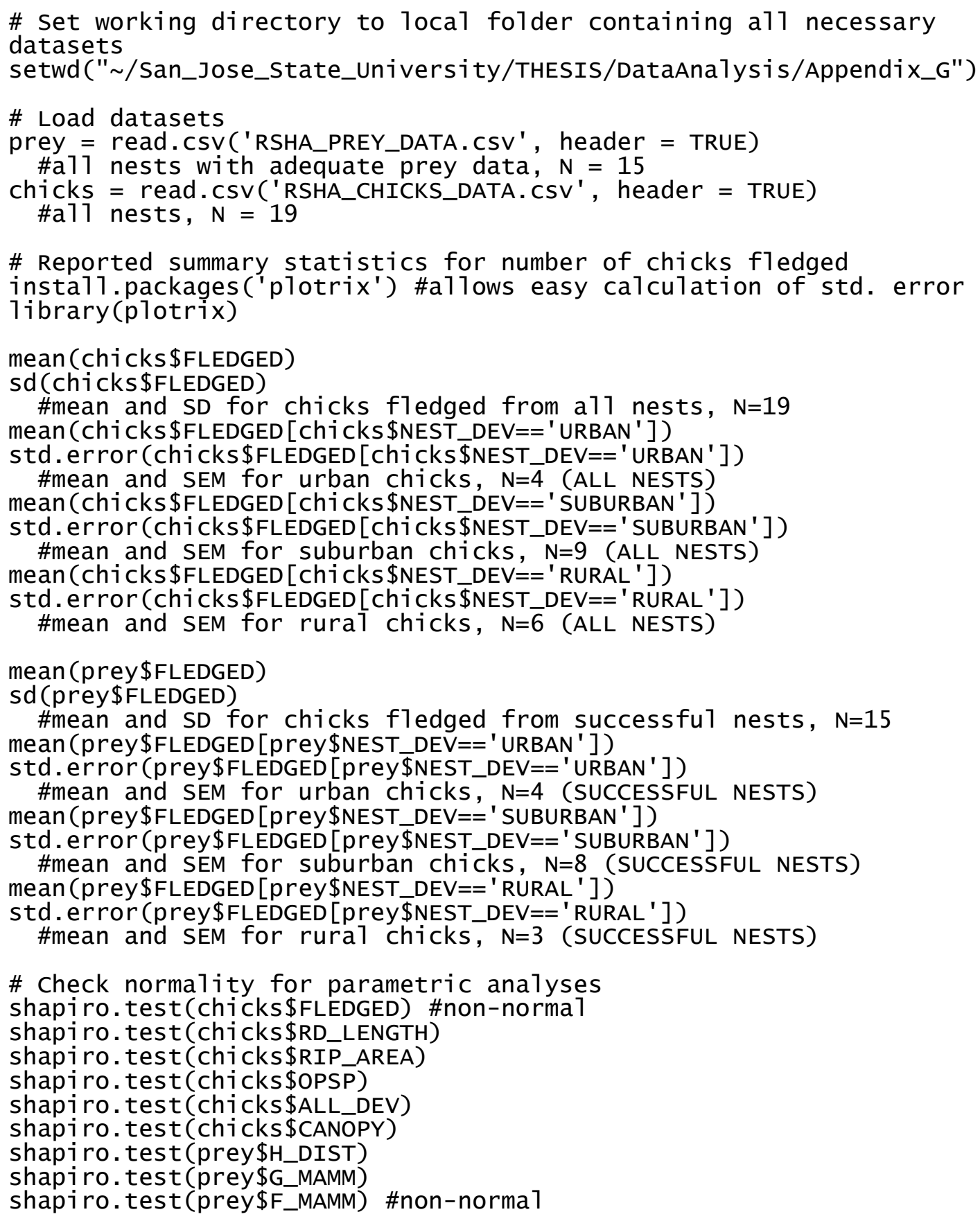




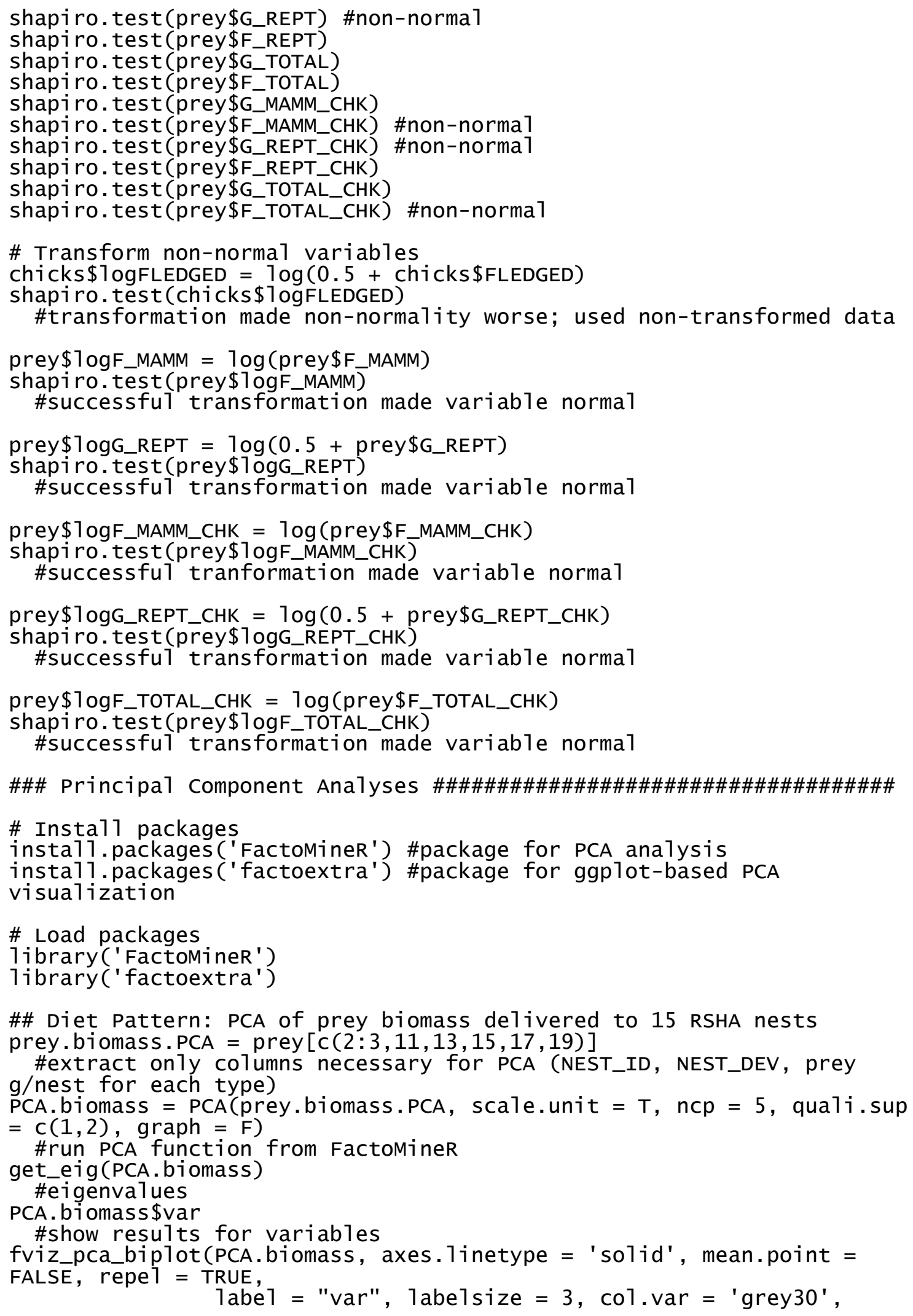


pointsize $=3$ ) +

habi11age $=$ 'NEST_DEV', pointshape = 'NEST_DEV',

scale_shape_manual (values $=c(19,17,15))+$

scale_color_manual (values = c("green", "blue", "red")) +

geom_text $(1 \overline{a b e} 1=\operatorname{rownames}($ prey.biomass. $P C A)$, nudge_x $=-0.09$,

nudge_y $=-0.05$, check_overlap = F) + theme_gray ()$+$

theme (legend.position $=c(0.9,0.9)$, 1egend.title $=$ element_blank () , legend. background = element_rect $(\operatorname{colour}=$ 'white'))

\#visualization of PCA

\#\# Diet Pattern: PCA of prey delivery frequency to 15 RSHA nests

prey. freq. PCA $=$ prey $[c(2: 3,12,14,16,18,20)]$

\#extract only columns necessary for PCA (NEST_ID, NEST_DEV, prey freq./nest for each type)

PCA. freq $=$ PCA(prey. freq.PCA, scale. unit $=T$, ncp $=5$, quali. sup $=$ $c(1,2)$, graph $=F)$

\#run PCA function from FactomineR

get_eig(PCA.freq)

\#eigenvalues

PCA. freq\$var

\#show results for variables

fviz_pca_biplot(PCA.freq, axes.1inetype = 'solid', mean.point = FALSE, repe 1 = TRUE,

pointsize $=3)+$

1abe1 = "var", 1abe1size $=3$, col $\cdot \operatorname{var}=$ 'grey30',

habi11age = 'NEST_DEV', pointshape = 'NEST_DEV',

scale_shape_manual (values $=c(19,17,15))+$

scale_color_manual (values = c("green","blue", "red")) +

geom_text $(1$ abe $1=$ rownames $($ prey.freq.PCA $)$, nudge_x $=0.09$, nudge_y $=$ -0.05 ,

check_overlap = F) + theme_gray ()$+$

theme (1egend.position $=c(0.1,0.9)$, 1egend.title $=$ element_blank () , legend.background = element_rect $(\operatorname{colour}=$ 'white')) \#visualization of PCA

\#\# Habitat Selection: PCA of nest 1ocations

chicks. 1ocation. PCA = chicks $[\mathrm{c}(2: 3,5: 9)]$

\#extract on1y columns necessary for PCA (NEST_ID, NEST_DEV, 5 habitat metrics)

PCA.1ocation = PCA(chicks.1ocation.PCA, scale.unit $=T, n c p=5$, quali.sup $=c(1,2)$,

$$
\text { graph }=F \text { ) }
$$

\#run PCA function from FactomineR

get_eig(PCA. 1ocation)

\#eigenvalues

PCA. 1ocation \$var

\#show results for variables

fviz_pca_biplot(PCA.1ocation, axes.1inetype = 'solid', mean. point $=$

FALSE, repe $1=$ TRUE,

pointsize $=3$ ) + 1abe1 = "var", 1abe1size $=3$, col.var = 'grey30',

scale_shape_manual (values $=c(19,17,15))+$

scale_color_manual (values = c("green", "blue", "red")) +

geom_text $(1 \bar{a}$ be $1=\operatorname{rownames}($ chicks.1ocátion.PCA), nudge_x $=0.09$, nudge_y $=-0.05$, check_overlap = F) + theme_gray ()$+$

theme (1egend.position $=c(0.9,0.9)$, 1egend.title $=$ element_blank () , legend.background = element_rect $(\operatorname{col}$ our $=$ 'white')) \#visualization of PCA 
\#\#\# Variables Influencing Chicks Fledged \#\#\#\#\#\#\#\#\#\#\#\#\#\#\#\#\#\#\#\#\#\#\#\#

\#\# Spearman Rank Correlations: Prey Biomass \& Frequency (Nest/Hr) FLEDGED.G_TOTAL = cor.test $(\sim$ FLEDGED + G_TOTAL, data = prey, method $=$ 'spearman',

$=F$ ) continuity $=$ FALSE, conf.1eve $1=0.95$, exact

FLEDGED.G_TOTAL \#show test resu1ts

FLEDGED.F_TOTAL $=$ cor. test $(\sim$ FLEDGED + F_TOTAL, data $=$ prey, method $=$ 'spearman',

$=F$ ) continuity $=$ FALSE, conf.1eve1 $=0.95$, exact

FLEDGED.F_TOTAL \#show test results

\#\# Spearman Rank Correlations: 5 Habitat Metrics

FLEDGED.RD_LENGTH = cor.test $(\sim$ FLEDGED + RD_LENGTH, data $=$ chicks, method = 'spearman',

exact $=F$ )

continuity = FALSE, conf. 1evel $=0.95$,

FLEDGED.RD_LENGTH \#show test results

FLEDGED.RIP_AREA $=$ cor.test $(\sim$ FLEDGED + RIP_AREA, data $=$ chicks, method $=$ 'spearman',

exact $=F$ )

continuity $=$ FALSE, conf. level $=0.95$,

FLEDGED.RIP_AREA \#show test results

FLEDGED.OPSP $=$ cor $\cdot$ test $(\sim$ FLEDGED + OPSP, data $=$ chicks, method $=$ 'spearman',

F) continuity $=$ FALSE, conf. 1eve1 $=0.95$, exact $=$

FLEDGED.OPSP \#show test results

FLEDGED.ALL_DEV $=$ cor $\cdot$ test $(\sim$ FLEDGED + ALL_DEV, data $=$ chicks, method $=$ 'spearman',

$=\mathrm{F}$ ) continuity $=$ FALSE, conf.1eve1 $=0.95$, exact

FLEDGED.ALL_DEV \#show test results

FLEDGED.CANOPY $=$ cor $\cdot$ test $(\sim$ FLEDGED + CANOPY, data $=$ chicks, method $=$ 'spearman',

$=\mathrm{F}$ ) continuity $=$ FALSE, conf.1eve1 $=0.95$, exact

FLEDGED.CANOPY \#show test results

\#\# Spearman Rank Correlation: Human Disturbance FLEDGED.H_DIST = cor $\cdot$ test $(\sim$ FLEDGED + H_DIST, data $=$ prey, method $=$ 'spearman',

$=\mathrm{F}$ ) continuity $=$ FALSE, conf.1eve1 $=0.95$, exact

FLEDGED.H_DIST \#show test results

\#\# Kruskal-Wal1is: Urbanization Categories (A11 Nests, $\mathrm{N}=19$ )

\# Initially attempted to use 1-way ANOVA, so tested for assumptions:

\# Assess normality of each category

shapiro.test (chicks\$FLEDGED[chicks\$NEST_DEV=='URBAN']) \#not norma1 shapiro.test (chicks\$FLEDGED[chicks\$NEST_DEV=='SUBURBAN']) \#norma1 shapiro.test (chicks\$FLEDGED [chicks\$NEST_DEV=='RURAL']) \#not norma1 
\# Assess homogeneity of variance between categories

fligner.test(FLEDGED NEST_DEV, data = chicks) \#not normal

\# Data does not meet assumptions for ANOVA

\# Use non-parametric analogue: Kruskal-wa11is Test

kruska1.test(FLEDGED NEST_DEV, data = chicks)

\# make boxplot for visualization

1ibrary(ggplot2) \#installed as part of package 'factoextra'

ggplot (chicks, aes (x=NEST_DEV, y=FLEDGED)) + geom_boxplot ()$+$ labs ( $x=$ 'Urbanization Category', $y=$ 'Number of Chicks Fledged') + stat_summary (fun $=$ mean, geom $=$ 'point', shape $=18$, size $=4$ )

\#\# Visualization for Urbanization Categories (Successful Nests, $N=15$ ) \# Low sample size prevented use of statistical analyses

\# make boxplot for visualization to compare to A11 Nests ggplot (prey, aes(X=NEST_DEV, y=FLEDGED)) + geom_boxplot ()$+$ labs ( $\mathrm{x}=$ 'Urbanization Category', $\mathrm{y}=$ 'Number of Chicks Fledged') + stat_summary (fun $=$ mean, geom $=$ 'point', shape $=18$, size $=4$ )

\#\#\# Variables Influencing Diet composition \#\#\#\#\#\#\#\#\#\#\#\#\#\#\#\#\#\#\#\#\#\#\#

\# H_DIST: Simple Linear Regressions with Normal Prey Components

\# G_TOTAL

H_DIST_LM1 $=1 \mathrm{~m}\left(\mathrm{G} \_T O T A L ~ \sim ~ H \_D I S T\right.$, data $=$ prey $)$ \#run 1inear mode1 summary(H_DIST_LM1) \#show test resu1ts

\# G_MAMM

H_DIST_LM2 $=7 \mathrm{~m}($ G_MAMM $\sim$ H_DIST, data $=$ prey) \#run 1inear mode1

summary (H_DIST_LM2) \#show test resu1ts

\# G_REPT (log-transformed)

H_DIST_LM3 $=1 \mathrm{~m}(10 \mathrm{gG}$ _REPT $\sim$ H_DIST, data $=$ prey $)$ \#run 1inear mode1

summary(H_DIST_LM3) \#show test resu1ts

\# F_TOTAL

H_DIST_LM4 $=1 \mathrm{~m}($ F_TOTAL $\sim$ H_DIST, data $=$ prey $)$ \#run 1inear mode1 summary(H_DIST_LM4) \#show test results \# F_MAMM (log-transformed)

H_DIST_LM5 $=1 \mathrm{~m}(10 \mathrm{gF}$ _MAMM $\sim$ H_DIST, data $=$ prey $)$ \#run 1inear mode1

summary(H_DIST_LM5) \#show test results

\# F_REPT

H_DIST_LM6 $=1 \mathrm{~m}\left(\mathrm{~F} \_\right.$REPT $\sim$ H_DIST, data $=$ prey $)$ \#run 1 inear mode1

summary(H_DIST_LMG) \#show test resu1ts

\# G_TOTAL_CHK

H_DIST_LM7 $=1 \mathrm{~m}($ G_TOTAL_CHK $\sim$ H_DIST, data $=$ prey) \#run 1inear mode1

summary (H_DIST_LM7) \#show test results

\# G_MAMM_CHK

H_DIST_LM $8=1 \mathrm{~m}$ (G_MAMM_CHK $\sim$ H_DIST, data $=$ prey) \#run 1 inear mode1

summary (H_DIST_LM8) \#show test results

\# G_REPT_CHK (1og-transformed)

H_DIST_LM9 $=1 \mathrm{~m}($ logG_REPT_CHK $\sim$ H_DIST, data $=$ prey) \#run 1 inear mode1

summary(H_DIST_LM9) \#show test results

\# F_TOTAL_CHK (1og-transformed)

H_DIST_LM10 $=1 \mathrm{~m}(10 \mathrm{~g} F$ FOTAL_CHK $\sim$ H_DIST, data $=$ prey) \#run 1inear mode1

summary(H_DIST_LM10) \#show test results

\# F_MAMM_CHK (1)og-transformed)

H_DIST_LM11 = 1m(1ogF_MAMM_CHK H_DIST, data $=$ prey) \#run 1inear mode1 summary(H_DIST_LM11) \#show test results 


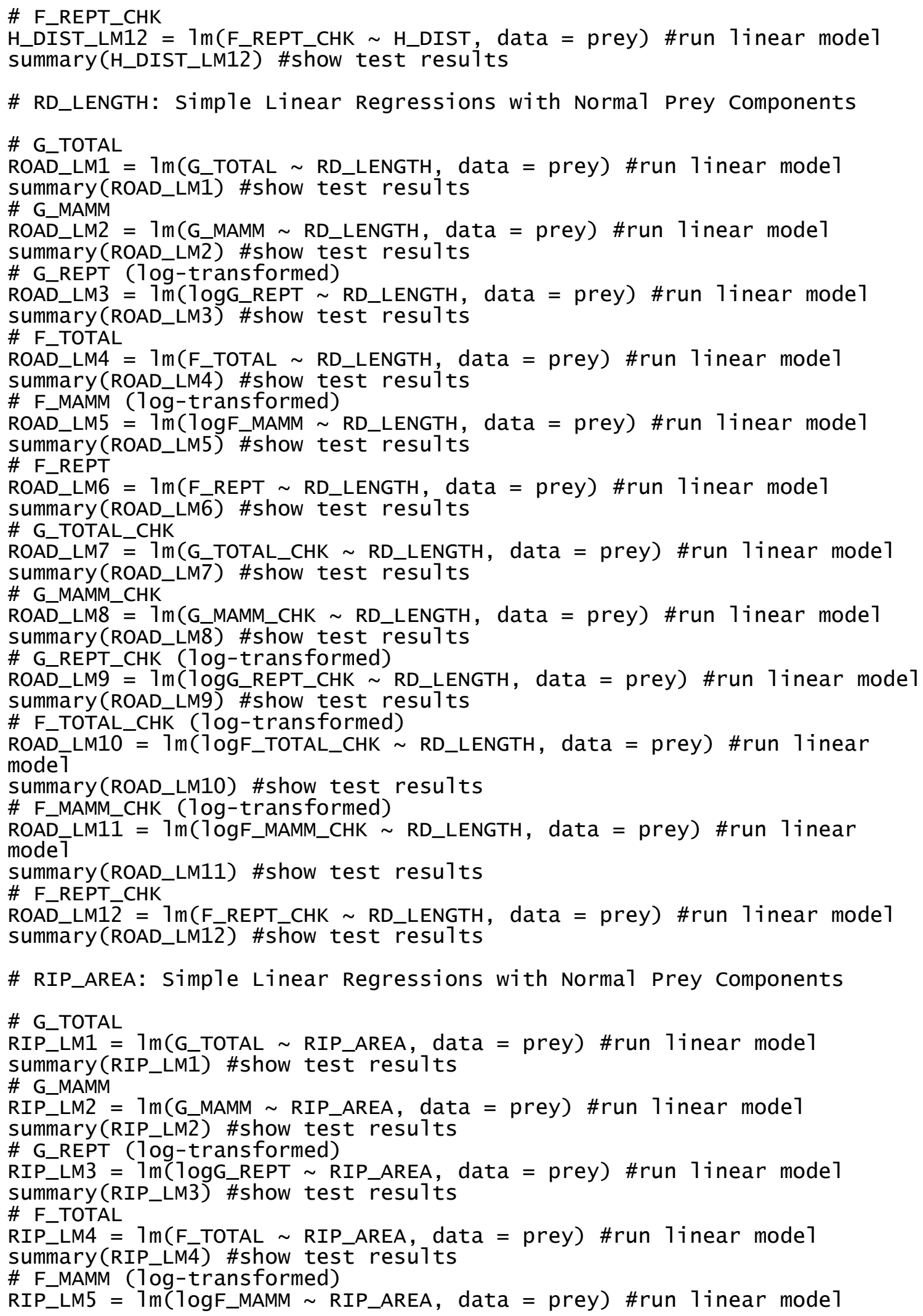




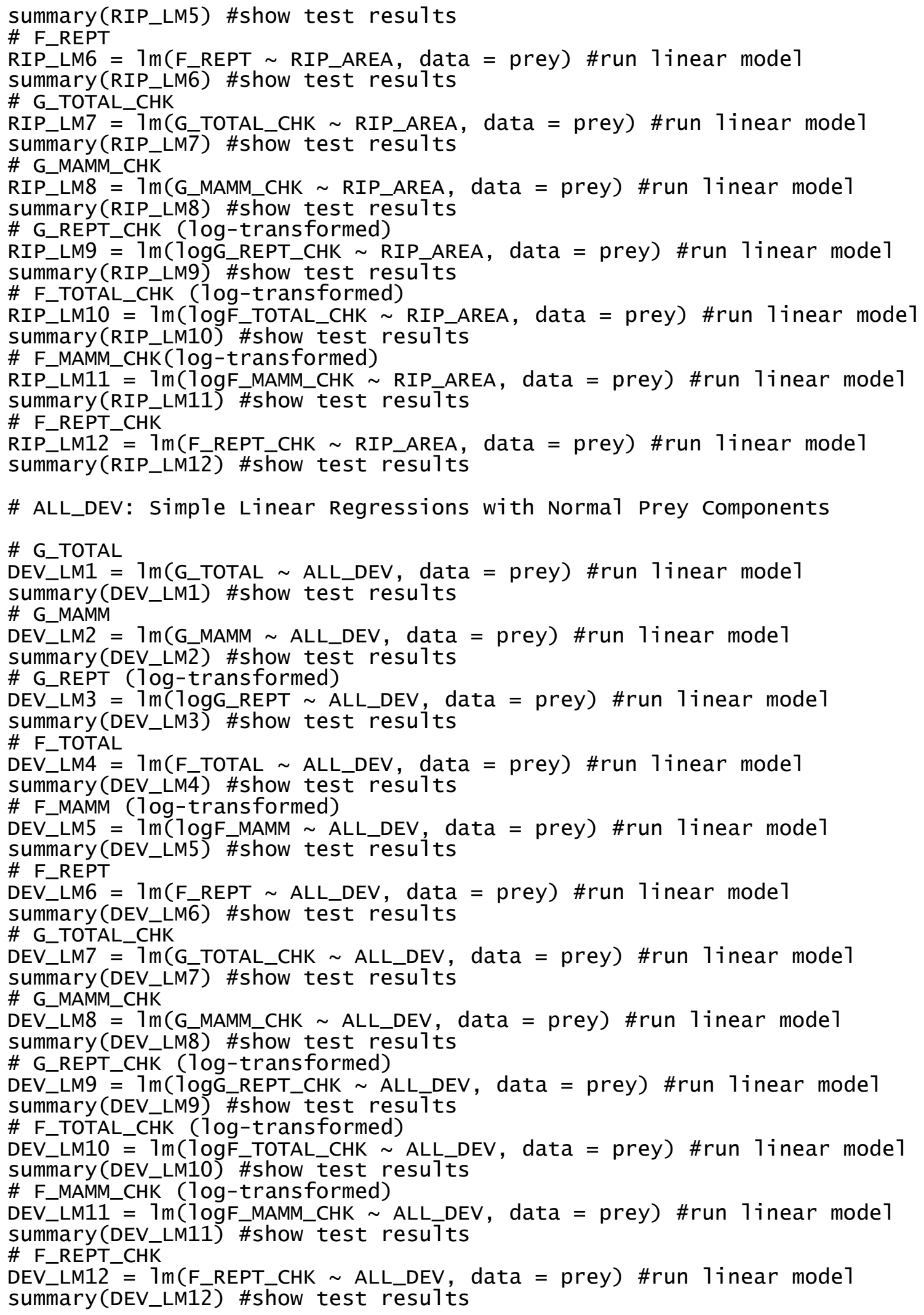


\# CANOPY: Simple Linear Regressions with Normal Prey Components

\# G_TOTAL

CANOPY_LM1 $=1 \mathrm{~m}(\mathrm{G}$-TOTAL $\sim$ CANOPY, data $=$ prey $)$ \#run 1inear mode1 summary(CANOPY_LM1) \#show test results

\# G_MAMM

CANOPY_LM2 $=1 \mathrm{~m}(\mathrm{G}$ MAMM $\sim$ CANOPY, data $=$ prey $)$ \#run 1 inear mode1

summary(CANOPY_LM2) \#show test results

\# G_REPT (1og-transformed)

CANOPY_LM3 $=1 \mathrm{~m}\left(10 \mathrm{gG} \_\right.$REPT $\sim$ CANOPY, data $=$ prey $)$ \#run 1inear mode1

summary(CANOPY_LM3) \#show test results

\# F_TOTAL

CANOPY_LM4 $=1 \mathrm{~m}\left(\mathrm{~F}_{-}\right.$TOTAL $\sim$ CANOPY, data $=$ prey $)$ \#run 1inear mode1

summary(CANOPY_LM4) \#show test results

\# F_MAMM (log-transformed)

CANOPY_LM5 $=1 \mathrm{~m}\left(10 \mathrm{~g} F \_\right.$MAMM $\sim$ CANOPY, data $=$ prey $)$ \#run 1inear mode1

summary(CANOPY_LM5) \#show test results

\# F_REPT

CANOPY_LM6 $=1 \mathrm{~m}(\mathrm{~F}$-REPT $\sim$ CANOPY, data $=$ prey $)$ \#run 1 inear mode 1

summary(CANOPY_LMG) \#show test results

\# G_TOTAL_CHK

CANOPY_LM7 $=1 \mathrm{~m}\left(\mathrm{G}_{-}\right.$TOTAL_CHK $\sim$ CANOPY, data = prey) \#run 1inear mode1

summary(CANOPY_LM7) \#show test results

\# G_MAMM_CHK

CANOPY_LM $8=1 \mathrm{~m}$ (G_MAMM_CHK $\sim$ CANOPY, data $=$ prey) \#run 1 inear mode1

summary (CANOPY LMB) \#show test results

\# G_REPT_CHK (1)og-transformed)

CANOPY_LM9 $=1 \mathrm{~m}\left(10 \mathrm{gG} \_\right.$REPT_CHK $\sim$ CANOPY, data $=$ prey $)$ \#run 1 inear mode1

summary (CANOPY_LM9) \#show test results

\# F_TOTAL_CHK (1og-transformed)

CANOPY_LM10 $=1 \mathrm{~m}\left(10 \mathrm{~g} F \_\right.$TOTAL_CHK $\sim$ CANOPY, data = prey) \#run 1inear mode1

summary (CANOPY_LM10) \#show test resu1ts

\# F_MAMM_CHK (1)og-transformed)

CANOPY_LM11 = 1m(logF_MAMM_CHK $\sim$ CANOPY, data $=$ prey) \#run 1 inear mode1

summary(CANOPY_LM11) \#show test results

\# F_REPT_CHK

CANOPY_LM12 $=1 \mathrm{~m}($ F_REPT_CHK $\sim$ CANOPY, data = prey $)$ \#run 1inear mode1

summary (CANOPY_LM12) \#show test resuits

\# OPSP: Simple Linear Regressions with Norma1 Prey Components

\# G_TOTAL

OPSP_LM1 $=1 \mathrm{~m}(\mathrm{G}$-TOTAL $\sim$ OPSP, data $=$ prey) \#run 1 inear mode1

summary(OPSP_LMI1) \#show test resu1ts

\# G_MAMM

OPSP_LM2 $=1 \mathrm{~m}(\mathrm{G}$ MAMM $\sim$ OPSP, data $=$ prey) \#run 1 inear mode1

summary(OPSP_LM2) \#show test results

\# G_REPT (1og-transformed)

OPSP_LM3 = $1 \mathrm{~m}\left(10 \mathrm{gG} \_\right.$REPT $\sim$ OPSP, data $=$ prey) \#run 1inear mode1

summary(OPSP_LM3) \#show test results

\# F_TOTAL

OPSP_LM4 $=1 \mathrm{~m}\left(\mathrm{~F}_{-}\right.$TOTAL $\sim$ OPSP, data $=$ prey) \#run 1 inear mode1

summary(OPSP_LM4) \#show test results

\# F_MAMM ( 1 og-transformed)

OPSP_LM5 $=1 \mathrm{~m}\left(10 \mathrm{~g} F \_\right.$MAMM $\sim$ OPSP, data $=$ prey $)$ \#run 1inear mode1

summary(OPSP_LM5) \#show test results

\# F_REPT

OPSP_LM6 $=1 \mathrm{~m}(\mathrm{~F}-\mathrm{REPT} \sim$ OPSP, data $=$ prey $)$ \#run 1inear mode1

summary(OPSP_LM $\overline{6}$ ) \#show test results 


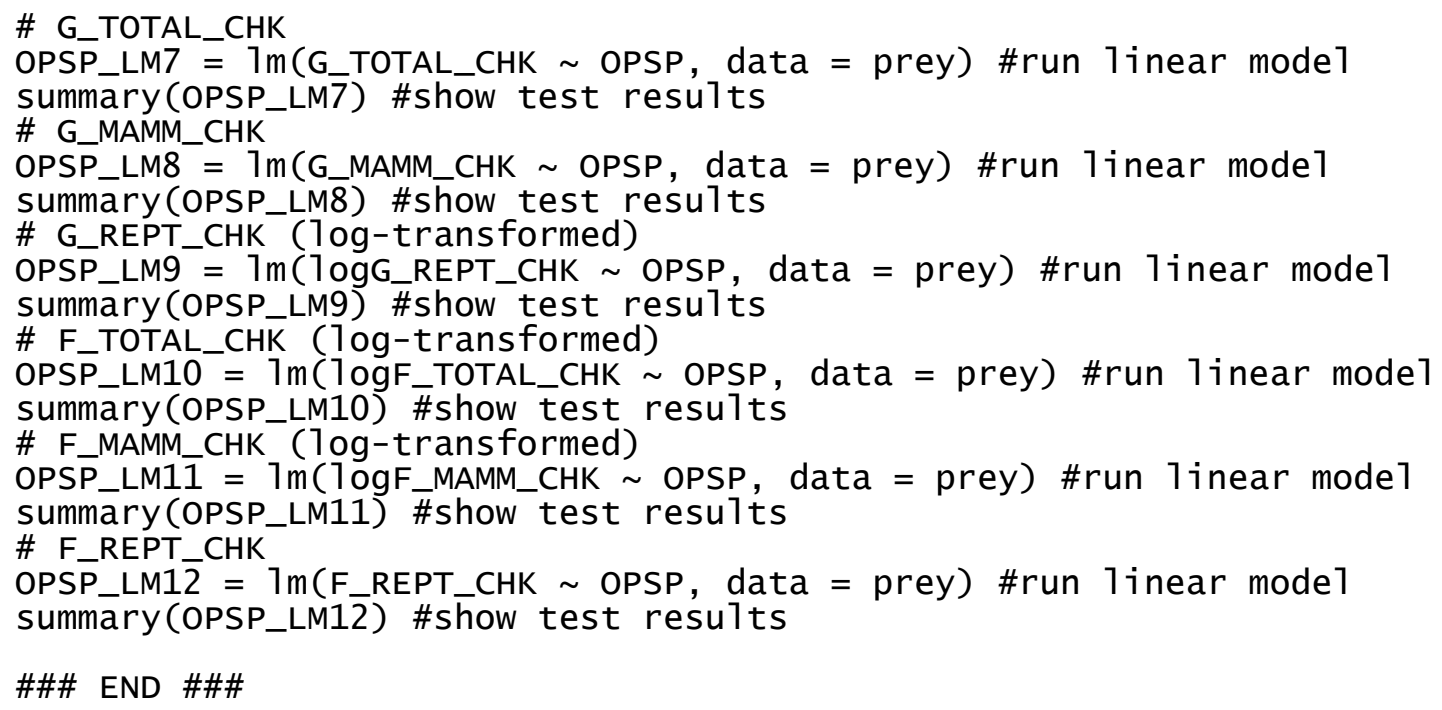

